\title{
PRISM Marine Sites: The History of PRISM Sea Surface Temperature Estimation
}

Open-File Report 2018-1148 



\section{PRISM Marine Sites: The History of PRISM Sea Surface Temperature Estimation}

By Marci M. Robinson, Harry J. Dowsett, Kevin M. Foley, and

Christina R. Riesselman

Open-File Report 2018-1148 


\title{
U.S. Department of the Interior \\ RYAN K. ZINKE, Secretary
}

\author{
U.S. Geological Survey \\ James F. Reilly II, Director
}

U.S. Geological Survey, Reston, Virginia: 2018

For more information on the USGS - the Federal source for science about the Earth, its natural and living resources, natural hazards, and the environment-visit https://www.usgs.gov or call 1-888-ASK-USGS.

For an overview of USGS information products, including maps, imagery, and publications,

visit https://store.usgs.gov.

Any use of trade, firm, or product names is for descriptive purposes only and does not imply endorsement by the U.S. Government.

Although this information product, for the most part, is in the public domain, it also may contain copyrighted materials as noted in the text. Permission to reproduce copyrighted items must be secured from the copyright owner.

Suggested citation:

Robinson, M.M., Dowsett, H.J., Foley, K.M., and Riesselman, C.R., 2018, PRISM3 marine sites-The history of PRISM sea surface temperature estimation: U.S. Geological Survey Open-File Report 2018-1148, 49 p.,

https://doi.org/10.3133/ofr20181148.

ISSN 2331-1258 (online) 


\section{Contents}

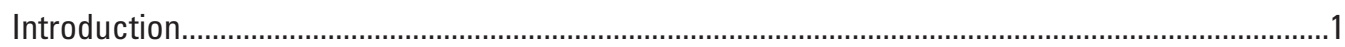

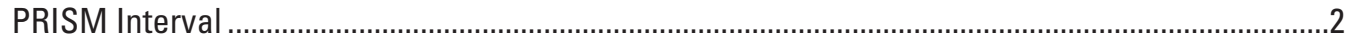

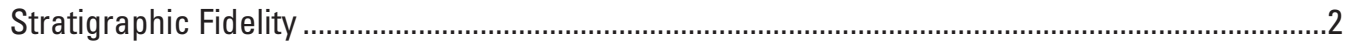

Sea Surface Temperature Estimation........................................................................................

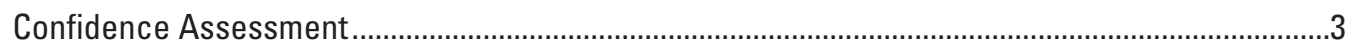

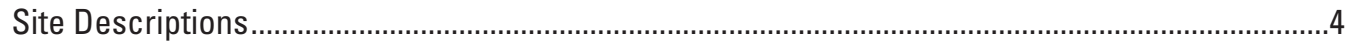

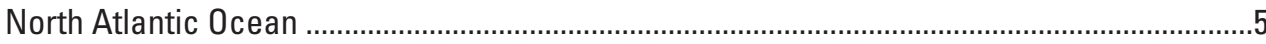

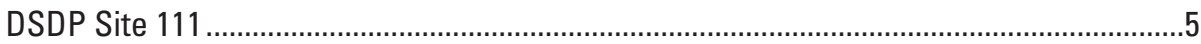

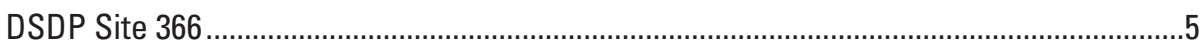

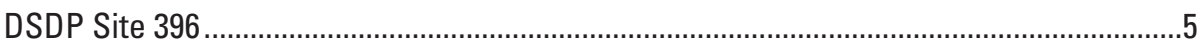

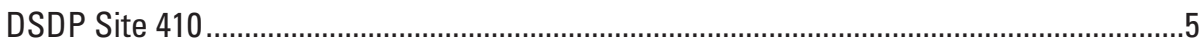

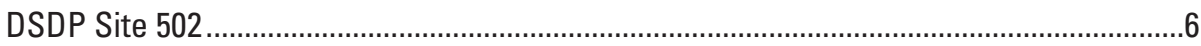

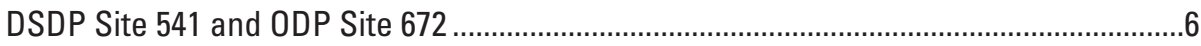

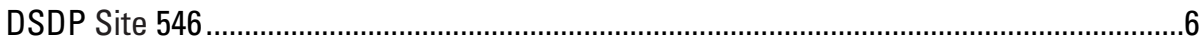

DSDP Site 548

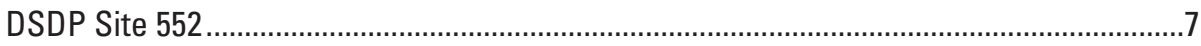

DSDP Site 603

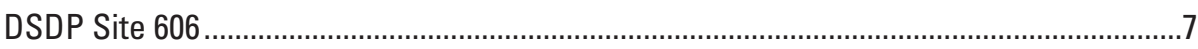

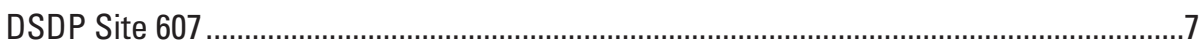

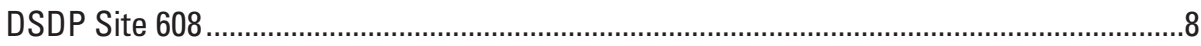

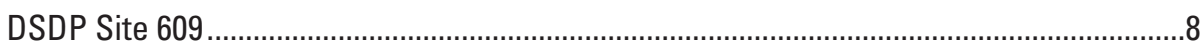

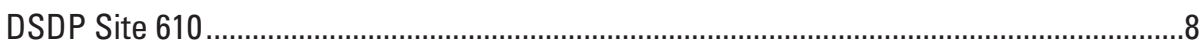

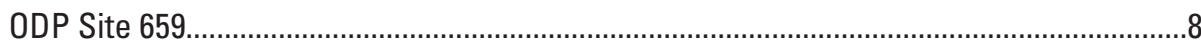

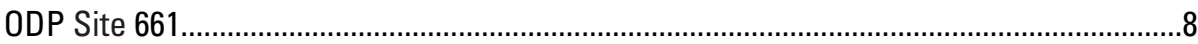

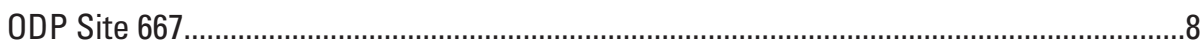

ODP Site 925

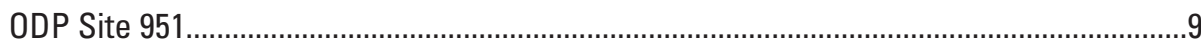

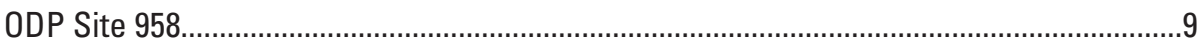

ODP Site 1006

ODP Site 1062

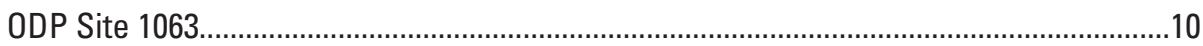

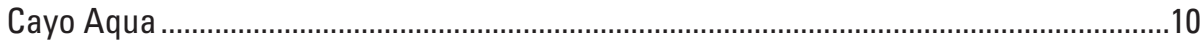

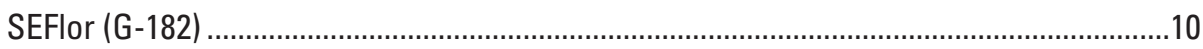

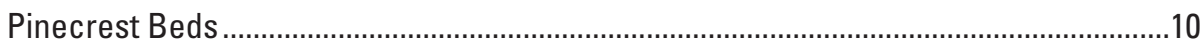

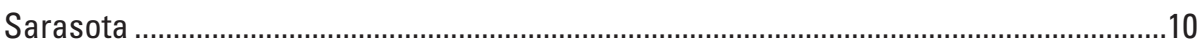

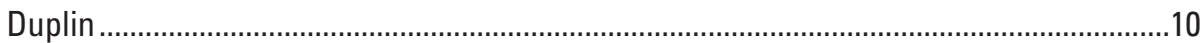

Lee Creek

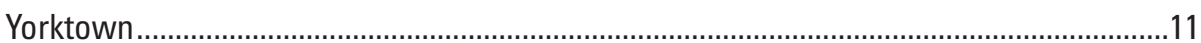

South Atlantic Ocean, Gulf of Mexico, and Mediterranean Sea ............................................11

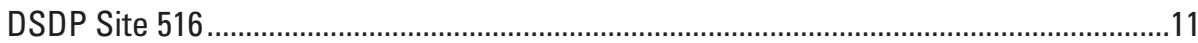

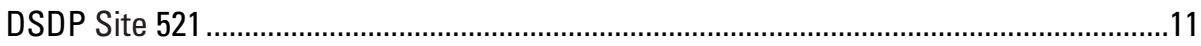

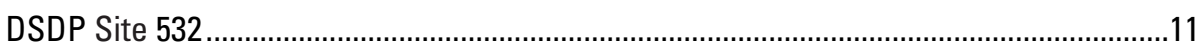

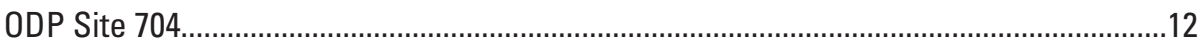




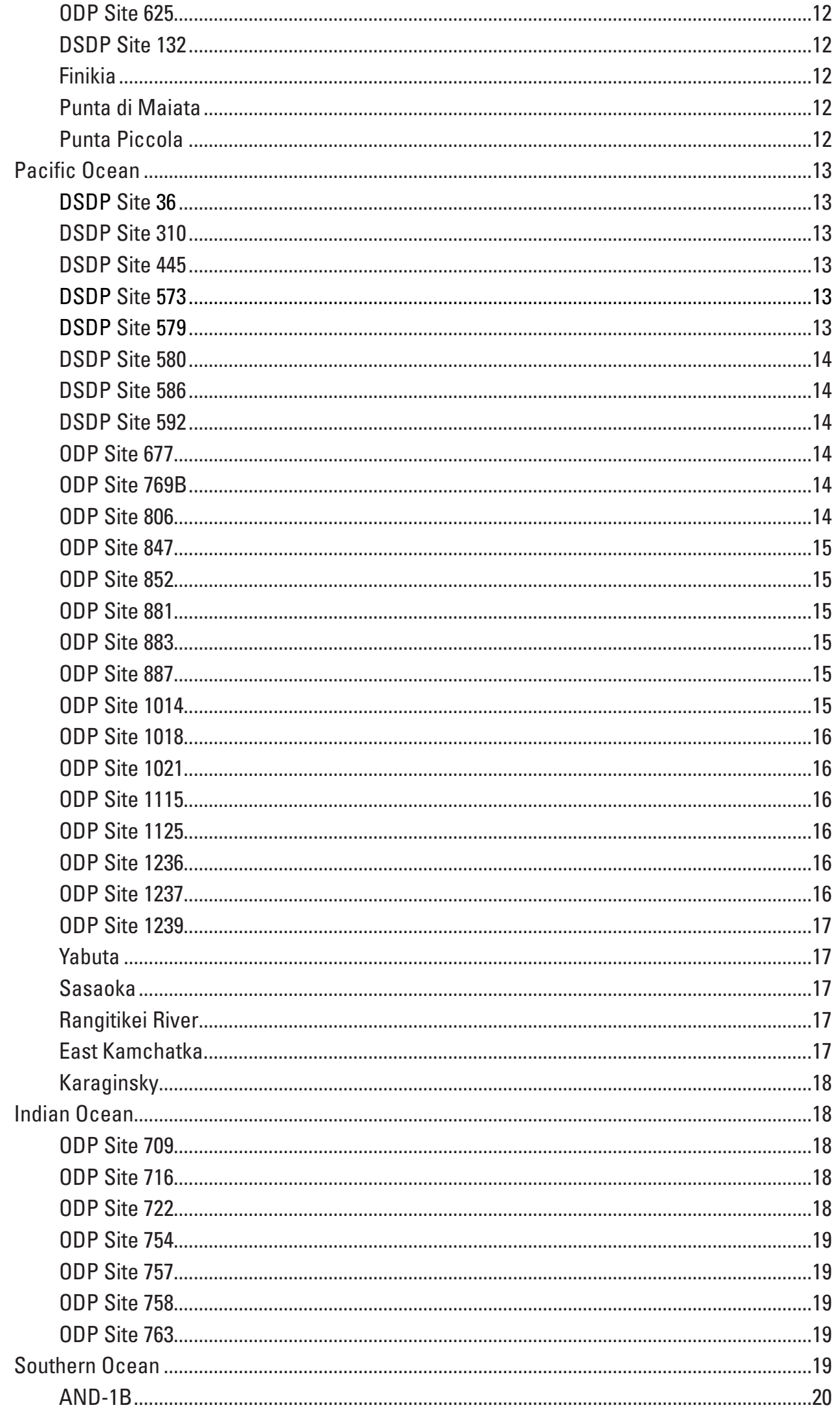


E13-17

E14-8

E36-33

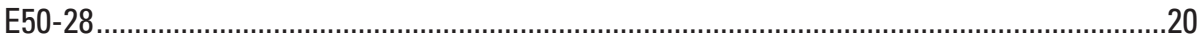

E50-33

PS1448

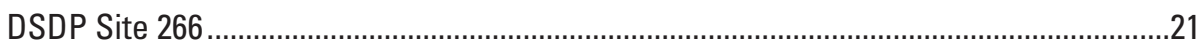

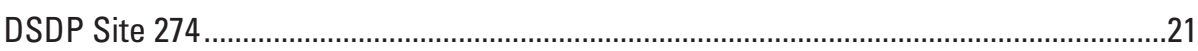

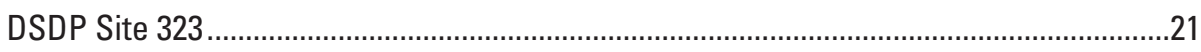

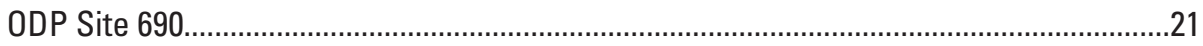

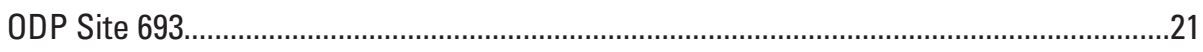

ODP Site 695

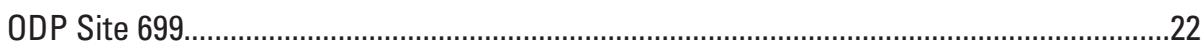

ODP Site 736

ODP Site 745

ODP Site 747

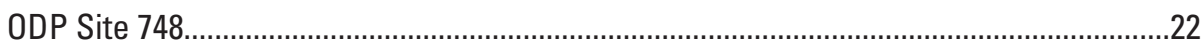

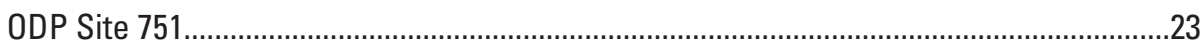

Northern High Latitudes ...............................................................................................2

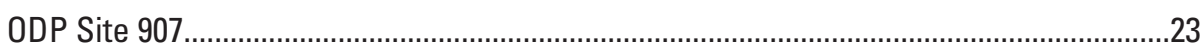

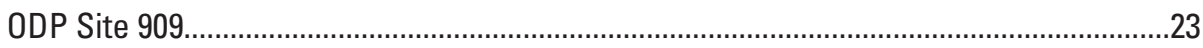

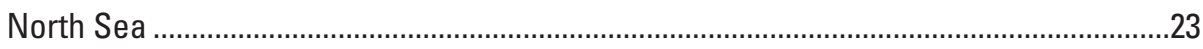

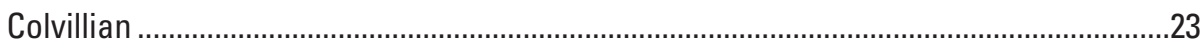

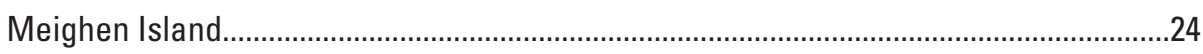

Sites Removed From the PRISM Sea Surface Temperature Dataset .....................................24

DSDP Site 183

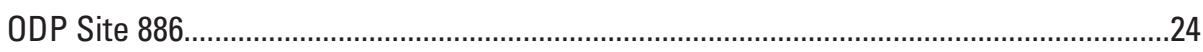

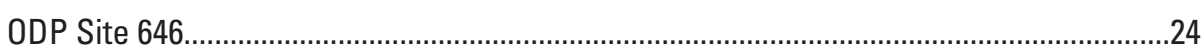

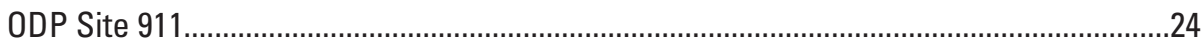

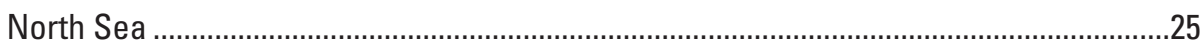

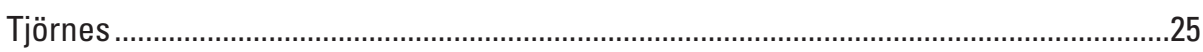

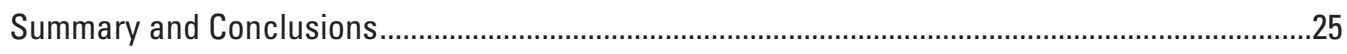

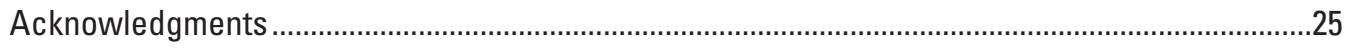

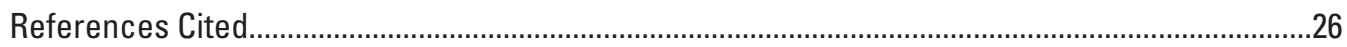

\section{Figures}

1. Maps showing locations of and sea surface temperature estimates for the PRISM3 interval at sites in the PRISM verification dataset..........................................41

2. Diagram showing the chronology of the PRISM interval ................................................43

3. Stratigraphic fidelity rubric showing rating by quality of age control and sampling resolution to scale the utility of individual records in model experiments requiring specific criteria

4. Scoring rubric for estimates of confidence in the sea surface temperature estimates for the mid-Piacenzian interval. 


\section{Table}

1. Mean annual sea surface temperature estimates for the mid-Piacenzian PRISM interval, measures of the confidence of the estimates, and stratigraphic fidelity for the sites in the PRISM verification dataset.

\section{Conversion Factors}

\begin{tabular}{|c|c|c|}
\hline Multiply & By & To obtain \\
\hline \multicolumn{3}{|c|}{ Length } \\
\hline centimeter $(\mathrm{cm})$ & 0.3937 & inch (in.) \\
\hline meter $(\mathrm{m})$ & 3.281 & foot $(\mathrm{ft})$ \\
\hline kilometer (km) & 0.6214 & mile (mi) \\
\hline kilometer (km) & 0.5400 & mile, nautical (nmi) \\
\hline meter $(\mathrm{m})$ & 1.094 & yard (yd) \\
\hline
\end{tabular}

Temperature in degrees Celsius $\left({ }^{\circ} \mathrm{C}\right)$ may be converted to degrees Fahrenheit $\left({ }^{\circ} \mathrm{F}\right)$ as ${ }^{\circ} \mathrm{F}=\left(1.8 \times{ }^{\circ} \mathrm{C}\right)+32$.

Temperature in degrees Fahrenheit $\left({ }^{\circ} \mathrm{F}\right)$ may be converted to degrees Celsius $\left({ }^{\circ} \mathrm{C}\right)$ as ${ }^{\circ} \mathrm{C}=\left({ }^{\circ} \mathrm{F}-32\right) / 1.8$.

\section{Abbreviations}

$\begin{array}{ll}\text { CLIMAP } & \text { Climate: Long-range Investigation, Mapping, and Prediction } \\ \text { DSDP } & \text { Deep Sea Drilling Project } \\ \text { IODP } & \text { Integrated Ocean Drilling Program or International Ocean Discovery Program } \\ \text { IPCC } & \text { Intergovernmental Panel on Climate Change } \\ \text { Mg/Ca } & \text { magnesium to calcium ratio } \\ \text { NCEI } & \text { National Centers for Environmental Information } \\ \text { ODP } & \text { Ocean Drilling Program } \\ \text { PRISM } & \text { Pliocene Research, Interpretation and Synoptic Mapping } \\ \text { SST } & \text { sea surface temperature } \\ \text { USGS } & \text { U.S. Geological Survey }\end{array}$




\title{
PRISM Marine Sites: The History of PRISM Sea Surface Temperature Estimation
}

\author{
By Marci M. Robinson, Harry J. Dowsett, Kevin M. Foley, and Christina R. Riesselman
}

\section{Introduction}

For more than three decades, the U.S. Geological Survey (USGS) Pliocene Research, Interpretation and Synoptic Mapping (PRISM) Project has compiled paleoenvironmental data with the goal of reconstructing global conditions during the warm interval in the middle of the Piacenzian Age of the Pliocene Epoch (about 3.3 to 3.0 million years ago [Ma]), leading to this interval being known as the PRISM interval. Because this is the most recent interval of time in which climatic conditions were similar to those expected in the near future (Masson-Delmotte and others, 2013), a global reconstruction of conditions from this interval offers an imperfect yet useful representation of near future conditions. PRISM data have led to a clear picture of mid-Piacenzian climate as one that, when compared to the modern climate, is warmer globally (Chandler and others, 1994; Lunt and others, 2010; Dowsett and others, 2011) with a reduced meridional gradient owing to warmer high-latitude temperatures (Dowsett and others, 1992; Robinson, 2009), a reduced equatorial gradient in the Pacific Ocean (Dowsett and Robinson, 2009), and higher sea level (Dowsett and Cronin, 1990; Raymo and others, 2009; Miller and others, 2012). PRISM data support the concept of an enhanced oceanic heat transport component to the climatic forcings that led to this warm interval (Dowsett and others, 1992, 2006; Robinson and others, 2011) and an altered oceanic thermal regime (Dowsett and others, 2009).

PRISM reconstructions (Dowsett, Robinson, Haywood, and others, 2010; Dowsett, Foley, and others, 2013; and references cited in both of these sources) have been used extensively as boundary conditions in general circulation model experiments aimed at better understanding Pliocene climate (Haywood and others, 2010, 2011). They have also served as hindcasting targets when testing the ability of climate models to simulate real climates of the past, an exercise in estimating a model's ability to accurately predict future climate (Haywood and Valdes, 2004). As data coverage has grown and model precision has improved, PRISM datasets have become important validation tools for pinpointing discrete areas of data-model disagreement (Dowsett and others, 2011, 2012) and model-model disagreement (Haywood and others, 2009, 2013; Dowsett, Foley, and others, 2013; Masson-Delmotte and others, 2013).

The Pliocene sea surface temperature (SST) dataset is the best developed component of the PRISM reconstructions, which also incorporate vegetation, topography, sea level, and deep ocean temperature data, and is the keystone of Pliocene paleoclimate research. For the first time, we compile all data related to PRISM SST estimation, to include those necessary to assign a measure of confidence. The PRISM SST verification dataset, specifically designed for data-model comparisons (Dowsett and others, 2012; Dowsett, Foley, and others, 2013), used multiple proxies of SST at 95 locations across the globe. Here we update the verification dataset by providing seven additional sites, revising SST estimates in the Indian Ocean, and removing one northern high-latitude site (Ocean Drilling Program [ODP] Site 911) based on a revision and improvement of the age model (fig. 1). In addition, we discuss why four sites included in previous PRISM publications were not included in the verification dataset. Finally, we assigned a measure of stratigraphic fidelity to each site in the verification dataset following Dowsett, Robinson, and Foley (2017; table 1).

Because this dataset is significant to understanding both past and future climate, the confidence of PRISM SST data has been assessed in order to make comparisons with model output more insightful (Dowsett and others, 2012). Following the confidence assessment criteria set forth in Dowsett and others (2012), the data were evaluated in terms of age control, sample density, sample quality, and method used, as well as the performance of the proxy method or technique used and the agreement between or among SST estimates when multiple proxies were used.

This discussion chronicles the history of PRISM SST research as it evolved, responding to advances in paleochronology and paleotemperature estimation. Paleoclimatic considerations unique to each location are illustrated, as are any new developments since the initial publication of the data. 


\section{PRISM Interval}

The Piacenzian Stage (3.60 to 2.58 Ma) of the Pliocene Epoch (5.33 to $2.58 \mathrm{Ma}$ ) was selected for detailed study by USGS research geologists because it spans the transition from relatively warm global climates when glaciers were absent or greatly reduced in the Northern Hemisphere to the generally cooler climates of the Pleistocene Epoch (2.58 to $0.0117 \mathrm{Ma})$ with expanded Northern Hemisphere ice sheets and prominent glacial-interglacial cycles. Downcore studies of marine microfossils (Cronin, 1991b; Dowsett and Poore, 1991; Barron, 1992; Dowsett and Loubere, 1992; Dowsett and others, 1992) and several studies of Pliocene high-latitude vegetation (Matthews and Ovenden, 1990; Webb and Harwood, 1991; Ballantyne and others, 2010) had established this period as a time of warmer-than-modern climate. Though many older warm periods had been identified, the Piacenzian is an attractive target because many fossil taxa encountered are extant. Thus, environmental interpretations derived from Piacenzian fossil assemblages are more likely to be reliable estimates of physical conditions than those derived from older assemblages containing higher percentages of extinct taxa.

Initially, the PRISM interval was defined as the period of about 300 thousand years (k.y.) centered on the warm interval at $\sim 3 \mathrm{Ma}$ (using Berggren and others, 1985) that had been identified in micropaleontologic studies. The interval from 3.15 to $2.85 \mathrm{Ma}$ (Dowsett and others, 1994, 1996) was long enough to be reliably identified and correlated between marine sequences from different ocean basins independent of climatic characteristics owing to its proximity to a number of biostratigraphic and magnetostratigraphic events (Berggren and others, 1985; Dowsett, 1989a,b). This interval incorporates oxygen isotopic stages M1 through K1 of Shackleton and others (1995) that occurred prior to the first evidence of major Northern Hemisphere glaciation, when polar fronts strengthened and glacial-interglacial variation intensified (Sancetta and Silvestri, 1986; Raymo and others, 1989; Hodell and Ciesielski, 1991; Shackleton and others, 1995). Other than stage KM2 and the bounding glacial stages M2 and G20, benthic foraminiferal oxygen isotope values within this interval were either equal to or isotopically lighter than those of today (Shackleton and others, 1995; Lisiecki and Raymo, 2005), adding to the ease in which this interval could be distinguished in core material.

Dowsett and others (1999) redefined the PRISM interval as a period of relatively warm and stable climate lying between the transition of oxygen isotope stages M2 and M1 and G19 and G18 (Shackleton and others, 1995) in the middle part of the Gauss Normal Polarity Chron, which was equivalent to 3.29 to 2.97 Ma using the updated geomagnetic polarity time scale of Berggren and others (1995). PRISM data collected or revised based on this updated chronology are part of the PRISM2 reconstruction (Dowsett and others, 1999). This new definition maintained the 300-k.y. window surrounding the warm interval originally identified in micropaleontologic studies, but with improved isotope chronology. The 300-k.y. window strategy was eventually abandoned in favor of more meaningful warm interval boundaries.

The PRISM interval was further refined in Dowsett, Robinson, Haywood, and others (2010) using the marine oxygen isotope stack of Lisiecki and Raymo (2005) to the period between the transition of marine isotope stages M2 and M1 (3.264 Ma) and G21 and G20 (3.025 Ma) in the middle part of the Gauss Polarity Chron (fig. 2). This interval ranges from C2An2r (Mammoth reversed polarity) to near the bottom of C2An1 (just above Kaena reversed polarity). This 239-k.y. interval correlates in part to planktic foraminiferal zones PL3 (Sphaeroidinellopsis seminulina Highest Occurrence Zone), PL4 (Dentoglobigerina altispira Highest Occurrence Zone), and PL5 (Atlantic) (Globorotalia miocenica Highest Occurrence Zone) or PL5 (IndoPacific) (Globorotalia pseudomiocenica Highest Occurrence Zone) of Wade and others (2011). PRISM data collected or revised to fit this updated chronology are part of the PRISM3 reconstruction (Dowsett, Robinson, Haywood and others, 2010). The PRISM verification dataset and the updates to it provided in this publication use PRISM3 chronology (Dowsett and others, 2012; Dowsett, Foley, and others, 2013).

More recently, Herbert and others (2015) revealed that the Pliocene segment of the Lisiecki and Raymo (2005) oxygen isotope stack may not be reliable at the orbital scale and may require some improvement. This work is underway and will likely result in further revision of the PRISM interval.

Although the published bounding ages of the PRISM interval have evolved over the history of the PRISM project, the climatically distinct period known as the PRISM interval has remained the same. It is the most recent stable (relative to late Pleistocene) interval of time when temperatures were warmer than in our modern climate, that is, the period in which climate has been affected by human influence. This interval is superimposed on the Pliocene cooling trend that ultimately led to the generally cooler Pleistocene climate with expanded Northern Hemisphere ice sheets and prominent glacial-interglacial cycles.

\section{Stratigraphic Fidelity}

The stratigraphic framework used to construct a paleoenvironmental reconstruction is its foundation. Accurately identifying the target chronostratigraphic interval in each record and correlating this interval precisely across records is of fundamental importance to PRISM research. Dowsett, Robinson, and Foley (2017) introduced a simple rating table to describe the 
stratigraphic fidelity of a geologic record (fig. 3). Considering only sampling resolution and the type (and therefore quality) of age control, time series data were categorized based solely on stratigraphic attributes regardless of proxy type or performance.

This metric can be used to filter available records into categories for specific applications, such as model experiments or paleoenvironmental studies. For example, only orbitally tuned sequences with $\leq 5-k$.y. (high) sample resolution (stratigraphic fidelity = 1a) would be appropriate for use as climate model verification data, whereas high-resolution sampling bracketed by paleomagnetic age control (stratigraphic fidelity $=2 \mathrm{a}$ ) or low-resolution sampling over an orbitally tuned section (stratigraphic fidelity $=1 \mathrm{c}$ ) may be appropriate for seasonality and (or) variability studies or studies across a climate transition, respectively. For each record discussed herein, a stratigraphic fidelity rating is shown in table 1.

\section{Sea Surface Temperature Estimation}

The PRISM interval is climatologically distinct from mean conditions immediately surrounding it; however, a high degree of variability exists within the interval (Dowsett and Poore, 1991; Barron, 1992; Hodell and Venz, 1992). PRISM researchers adopted a strategy whereby a single estimate of mean warm peak conditions within the interval was reported at each site. This not only minimized the problems associated with correlating individual warm and cold peaks within the interval between sites separated by large geographic distances (Dowsett and Poore, 1991) but also focused on the warmer parts of the PRISM interval that are more analogous to modern conditions. Therefore, multiple SST estimates covering the interval at each site were culled to only warm peaks, and these were averaged to assign a single paleotemperature estimate to each site.

Originally, all paleotemperature estimates were derived from fossil assemblages. Estimates based on planktic foraminifera were derived using either a factor analytic transfer function (Dowsett, 1991) modeled after the Climate: Long-range Investigation, Mapping, and Prediction (CLIMAP) functions or a revised modern analog technique (MAT) (Dowsett and Robinson, 1998; Waelbroeck and others, 1998; Dowsett, 2007) with modifications to allow for extension to Pliocene age assemblages. In both methods, the Pliocene fossil assemblage was compared with modern assemblages.

Poor carbonate preservation in many regions of the Pacific Ocean made siliceous microfossils (diatoms and radiolaria) a better choice for quantitative temperature estimation in some locations (Hays and others, 1989; Barron, 1992, 1995, 1996a,b). Diatoms were used almost exclusively in the Southern Ocean where they are excellent indicators of the position of the sea-ice margin and Antarctic polar fronts; assumptions of a polar front thermal structure similar to modern allows estimation of SST around the reconstructed Pliocene polar front (Barron, 1995, 1996b; Dowsett and others, 1996). In marginal marine and shallow water regions, analyses of mollusk and ostracod assemblages (for example, Cronin and Dowsett, 1990; Cronin, 1991b; Gladenkov and others, 1991; Ikeya and Cronin, 1993) provided additional geographic coverage for the dataset.

With the development of multiple independent paleotemperature methodologies, multiple proxies were employed to confirm initial paleoenvironmental estimates wherever possible (for example, Robinson, Dowsett, and others, 2008). The addition of estimates of magnesium to calcium ratios $(\mathrm{Mg} / \mathrm{Ca})$ from shallow dwelling planktic foraminifera and alkenone paleothermometry has provided a more robust understanding of the paleoenvironmental setting (Dowsett and Robinson, 2009; Dowsett, Robinson, and others, 2013).

\section{Confidence Assessment}

An assessment of confidence in SST estimates can be achieved through the understanding of modern and paleoceanographic settings and indepth knowledge of the fossil material and methodologies used for analysis. In recognition of the Intergovernmental Panel on Climate Change (IPCC) focus on measures of uncertainty, Dowsett and others (2012) developed a new confidence metric for evaluating and communicating confidence in PRISM SST verification data. Following principles outlined by the IPCC (Mastrandrea and others, 2010), this semiquantitative confidence metric is applicable across a variety of paleoenvironmental proxy methodologies, provides a traceable account of the steps leading to the overall confidence assessment, and includes a measure of expert subjectivity necessary to support any meaningful uncertainty calculation.

While we understand the desire for fully statistical probabilistic confidence intervals in paleothermometry estimates, we argue that such calculations would violate statistical principles and provide faulty estimates. That is, in paleoclimate studies, too many uncertainties, such as stationarity of environmental tolerances or ocean chemistry, are inherently nonquantifiable. These are known unknowns, and other unknowns are likely to exist. The semiquantitative confidence metric is advantageous when working with paleoestimates, as expert subjectivity incorporates an understanding of modern and paleoceanographic settings, fossil species and geochemistry, and methodologies used for analysis. In our opinion, an extensive analysis of the quantifiable attributes of a paleoenvironmental estimate, supported by a qualitative assessment of uncertainty related to the complexity of the record, provides the most honest and useful measure of confidence. 
The confidence placed on a paleoenvironmental estimate is directly related to a number of quantifiable attributes and can be expressed as:

$$
\lambda=\sum_{i=1}^{n} b_{i}
$$

where $\lambda$ represents confidence and $\boldsymbol{b}_{\boldsymbol{i}}$ are empirically derived scores for the following confidence attributes: age control, sample density, sample quality, proxy method, and performance of method (Dowsett and others, 2012; fig. 4). The $\lambda$ index ranges from 0 to 18 and is subcategorized as very high (16 to 18), high (13 to 15), medium (9 to 12), and low (5 to 8). Site descriptions contained herein are designed to address the following confidence attributes.

$\boldsymbol{b}_{\mathbf{1}}$-Age Control. Chronological confidence is a measure of the quality of the age estimate. An orbitally tuned isotopic record, for example, or a complete record of paleomagnetic reversals through the Pliocene earns a higher confidence than does a small number of first or last fossil appearances calibrated to the paleomagnetic timescale in another region. Implied within the age control metric is the requirement that samples fall within the PRISM interval. At a few PRISM sites (for example, Tjörnes, Iceland), samples originally thought to fall within the interval have more recently been excluded from the PRISM dataset owing to a refining of the age model at those sites.

$\boldsymbol{b}_{2}$ - Sample Density. The number of samples within the PRISM interval affects the confidence placed in the SST estimate. In short, a greater number of samples increases the chance of capturing the complete temperature variability; the highest confidence (maximum score of 4 for this attribute) comes from those locations with 20 or more samples within the PRISM interval.

$\boldsymbol{b}_{3}$-Sample Quality. Abundance and preservation of fossil specimens define sample quality. A larger sample size is more likely to capture the rare elements of the fauna; at least 300 specimens per sample are required to attain statistical confidence and avoid potential bias in the assemblage (Hay, 1972). Even in abundant samples, preservation is important because dissolution can selectively remove elements of the fauna and result in biased temperature results. For example, preferential dissolution of fragile warm-water species would drive temperature estimates cooler. Sample quality is assessed differently for various paleothermometry methods. Microfossil samples are scored based on their level of abundance and degree of preservation. $\mathrm{Mg} / \mathrm{Ca}$ samples require that no geochemical alteration be present, and alkenone samples require that the total concentration of $\mathrm{U}^{\mathrm{k}^{\prime}}{ }_{37}$ is $\geq 0.3 \mu \mathrm{g} / \mathrm{g}$. Samples that do not meet these thresholds are not included in the analysis.

$\boldsymbol{b}_{4}$ - Proxy Method. The main estimation methods used for the Pliocene dataset are transfer functions and modern analog techniques based on faunal assemblages, $\mathrm{Mg} / \mathrm{Ca}$, and alkenone unsaturation ratios. These yield quantitative estimates that are considered better than qualitative estimates simply because they are reproducible. A semi-quantitative method might estimate SST based on the modern ecological limits of extant species in the fossil sample. An example of a qualitative estimate is temperature estimation based on the comparison of fossil diatom assemblages to modern assemblages found at the polar front and the temperature at the modern polar front.

$b_{5}$-Proxy Performance. The performance of the method is considered as part of the confidence assessment. For example, performance of a transfer function is based on communality, the measure of how well the fossil assemblage can be described by the modern factors (assemblages); a communality of $\geq 0.8$ indicates a strong performance. Performance of the modern analog technique is based on the multivariate distance (squared chord distance [SCD]) between the fossil assemblage and its closest modern analogs and the agreement in temperature among those closest analogs; an SCD of $\leq 0.2$ indicates a strong performance (Hutson, 1980). Temperature estimates from $\mathrm{Mg} / \mathrm{Ca}$ analyses may be affected by a number of factors, including the calcification depth of the species analyzed and temporal changes in salinity at the study site; shallow calcification depths and lack of salinity changes indicate greatest performance. Because the alkenone temperature equation is calibrated to temperatures between 8 and 25 degrees Celsius $\left({ }^{\circ} \mathrm{C}\right.$ ) and to locations between $60^{\circ} \mathrm{N}$. and $60^{\circ} \mathrm{S}$. latitude, proxy performance carries less confidence outside these boundaries. Finally, the performance of temperature estimates based on diatom assemblages is scored according to the percent of extant taxa; samples with more than one-half extant taxa indicate greatest performance.

\section{Site Descriptions}

Planktic foraminifer census data for all sites at which the faunal identifications were initiated by PRISM workers can be accessed at the National Centers for Environmental Information (NCEI) (https://www.ncdc.noaa.gov/paleo/study/19281; Dowsett and others, 2015; Foley and others, 2015). In some instances, planktic foraminifer faunal work was completed by nonUSGS researchers. The original citations for any non-USGS data and for data from other proxies appear in the site descriptions. Alkenone data analyzed for the PRISM project can be found in Dowsett, Foley, and others (2017).

SST estimates presented here refer to the PRISM3 interval (3.264 to $3.025 \mathrm{Ma}$ ). In some cases, the ages of analyzed samples extended beyond the PRISM3 interval. Although samples known to be outside the PRISM3 interval were not used for 
SST estimation, they are included in the site descriptions in order to document the full PRISM sample holdings and for calculations of stratigraphic fidelity. In other cases, the bounds of the PRISM3 interval are uncertain owing to age model limitations, and it is likely that some samples outside the interval have been included in SST estimation that would have been excluded with better age control. Age model quality is reflected in the confidence assessments of the SST estimates.

\section{North Atlantic Ocean}

Owing to its importance in climate studies, the North Atlantic Ocean was our most densely and most carefully studied region. SST estimates in this region merited our highest confidence.

\section{DSDP Site 111 (50.43 N., $46.37^{\circ}$ W., 1,979-meter water depth)}

This site was not included in the Dowsett and others (2012) verification dataset. The mean annual SST at this site in the North Atlantic Ocean was estimated to be $15.2^{\circ} \mathrm{C}$ with high confidence. The age model was determined using biostratigraphy (Berggren, 1972; Shipboard Scientific Party, 1972). A factor analytic transfer function returned communalities of $>0.9$ on 20 Hole 111A samples ranging from 4 to $2.3 \mathrm{Ma}$ (Dowsett and Poore, 1990; Foley and others, 2015). Temperature estimation was based on five mid-Piacenzian samples. Foraminifer specimens were abundant and well preserved throughout the PRISM3 interval (Shipboard Scientific Party, 1972).

\section{DSDP Site 366 (5.68 N., $19.85^{\circ}$ W., 2,853-meter water depth)}

The mean annual SST at this site in the North Atlantic Ocean was estimated to be $27.5^{\circ} \mathrm{C}$ with high confidence (Dowsett and others, 2012). The age model at this site was based on biostratigraphy (Čepek and others, 1978). Foraminifera were abundant and well preserved in 11 Hole 366A samples ranging from 5.58 to $2.53 \mathrm{Ma}$ (Dowsett and others, 1988, 1996). Transfer function SST estimates showed good communalities averaging 0.86 .

\section{DSDP Site 396 (22.90 N., $43.50^{\circ}$ W., 4,450-meter water depth)}

Site 396 is located within the southern part of the North Atlantic gyre on the eastern flank of the Mid-Atlantic Ridge just south of the Kane fracture zone. The PRISM3 mean annual SST at DSDP Site 396 was estimated to be $26.1{ }^{\circ} \mathrm{C}$ with high confidence (Dowsett and others, 2012). Chronology at this North Atlantic site was based on calcareous nannofossil and planktic foraminiferal biostratigraphy (Bukry, 1978). Several of the samples contained a mixed nannofossil assemblage precluding precise dating and raising the possibility that the foraminifer assemblages had been altered by reworking or drilling disturbances; 14 samples ranging in age from 3.59 to $2.95 \mathrm{Ma}$ that did not show obvious signs of mixing were used for SST estimation (Dowsett and Poore, 1991; PRISM Project Members, 1996). Foraminifera were abundant and well preserved in these samples (Wiggs and Dowsett, 1992). SST estimation using a transfer function performed very well with communalities $>0.9$ (Dowsett and Poore, 1991).

\section{DSDP Site $410\left(45.51^{\circ}\right.$ N., $29.48^{\circ}$ W., 2,976-meter water depth)}

Site 410 is near the northern margin of the North Atlantic gyre on the west side of the Mid-Atlantic Ridge. The mean annual SST at DSDP Site 410 in the North Atlantic was estimated to be $20.6{ }^{\circ} \mathrm{C}$ with high confidence (Dowsett and others, 2012). Sediments from Hole 410 consist of an upper Miocene through Quaternary section of nannofossil ooze containing abundant and well preserved planktic foraminifera and calcareous nannofossils (Poore and others, 1978). Chronology at this site was based on graphic correlation, showing a hiatus within the PRISM interval (Dowsett, 1989a). Twelve samples ranging in age from 3.18 to 2.58 Ma were collected for faunal analysis (Dowsett and others, 1988; PRISM Project Members, 1996). Planktic foraminifer data from Site 410 were analyzed by Poore (1978) and Dowsett and others (1988). Planktic foraminifera were abundant and well preserved (Dowsett and others, 1988). The SST estimate, found using a transfer function, was an average of oldest estimates above the hiatus and represented a conservative estimate of warming. The average communality was 0.884 (Dowsett and Poore, 1991). 


\section{DSDP Site 502 (11.49 N., $79.38^{\circ}$ W., 3,051-meter water depth)}

DSDP Site 502 is located on a silled basin in the Caribbean Sea, due north of Colon, Panama. Mean annual SST was estimated to be $27.9^{\circ} \mathrm{C}$ with very high confidence (Dowsett and others, 2012). Four holes cored at Site 502 (Holes 502, 502A, 502B, and 502C) can be combined to form a complete, relatively undisturbed late Miocene to Pleistocene sequence. The age model for this site was based on an incomplete paleomagnetic record combined with an oxygen isotope record to improve chronology (Dowsett, 1989a). All paleomagnetic reversals between the Brunhes and the bottom of the Therva event ( 4.77 Ma) were identified by Kent and Spariosu (1982). The chronology of Site 502 was based directly on the magnetobiostratigraphy developed in Dowsett (1989a). Accumulation rates at Site 502 averaged 3.0 centimeters per thousand years (cm/k.y.). Hole 502A contains well preserved, abundant planktic foraminifera and calcareous nannofossils in Pliocene sediments (Keigwin, 1982; Dowsett, 1989a). Poore and Gosnell (1990) developed quantitative paleoclimate estimates for the Pliocene from planktic foraminiferal assemblages contained in the cores. Seventy Hole 502A faunal samples ranging from 3.6 to 2.9 Ma were analyzed (PRISM Project Members, 1996). The transfer function worked well with communalities ranging from 0.53 to 0.87 , averaging 0.71 (Dowsett and Poore, 1991).

\section{DSDP Site 541 ( $15.50^{\circ}$ N., $58.73^{\circ}$ W., 4,940-meter water depth) and ODP Site $672\left(15.50^{\circ}\right.$ N., $58.50^{\circ}$ W., 4,975-meter water depth)}

Sites 541 and 672 are located about 6 kilometers $(\mathrm{km})$ east of the Barbados Ridge deformation front, north of the island of Barbados and east of the island of Dominica. Records from these two closely located sites were combined to yield a single mean annual SST estimate of $27.2^{\circ} \mathrm{C}$ with high confidence (Dowsett and others, 2012). Paleomagnetic data were weak in DSDP Hole 541 and nonexistent in ODP Hole 672A, so the age models were based on foraminiferal and calcareous nannofossil biostratigraphy (Wilson, 1984; Shipboard Scientific Party, 1988a). Foraminifera were generally abundant and well preserved (Dowsett and Polanco, 1992; Wiggs and Dowsett, 1992). The analysis used 33 DSDP Hole 541 samples ranging from 3.42 Ma to 2.33 Ma and 39 ODP Hole 672A samples ranging from 3.95 to 2.52 Ma (PRISM Project Members, 1996). Sample density was poor within the PRISM interval at each site separately but improved when combined to achieve an average temporal resolution of about 32 k.y. Transfer function communalities ranged from 0.22 to 0.87, averaging 0.65 at DSDP Site 541 (PRISM Project Members, 1996), and ranged from 0.81 to 0.96, averaging 0.90 at ODP Site 672 (Dowsett and Poore, 1991).

\section{DSDP Site 546 (33.80 N., $9.60^{\circ}$ W., 3,958-meter water depth)}

The mean annual SST at DSDP Site 546 in the North Atlantic was estimated to be $21.6{ }^{\circ} \mathrm{C}$ with high confidence (Dowsett and others, 2012). The age model at this site was based on integrated magnetobiostratigraphy (Shipboard Scientific Party, 1984). Foraminifera were abundant and well preserved in 34 samples ranging in age from 3.36 to 1.89 Ma (Dowsett and Polanco, 1992 ; PRISM Project Members, 1996). Applying the factor analytic transfer function GSF18 (Dowsett and Poore, 1990; Dowsett, 1991 ) to these samples resulted in good communalities, averaging 0.72 .

\section{DSDP Site 548 (48.85 N., $12.00^{\circ}$ W., 1,251-meter water depth)}

DSDP Site 548 is located approximately $500 \mathrm{~km}$ west of Lands End, England, on the Goban Spur region of the European continental slope. The mean annual SST at DSDP Site 548 in the northeast Atlantic was estimated to be $23.0^{\circ} \mathrm{C}$ with very high confidence (Dowsett and others, 2012). Limited paleomagnetic stratigraphy data were available for the Pliocene section, and only the top and bottom of the Olduvai normal subchron were identified with confidence (Townsend, 1985). The chronology for Site 548 had been established through graphic correlation of calcareous nannofossil, planktic foraminifer, and paleomagnetic data (Dowsett and Loubere, 1992). Estimates were conducted using 146 samples ranging from 3.55 to 1.93 Ma (PRISM Project Members, 1996). The original faunal data appear in Loubere and Moss (1986). Calcareous nannofossils and planktic foraminifera are abundant and well preserved at this site (Loubere and Jakiel, 1985; Müller, 1985; Pujol and Duprat, 1985; Snyder and Waters, 1985; Loubere and Moss, 1986). SST estimates were based on application of a transfer function to foraminiferal data initially presented in Dowsett and Poore (1991) and at higher resolution in Dowsett and Loubere (1992), and resulted in good communalities, averaging 0.77. 


\section{DSDP Site 552 ( $56.04^{\circ}$ N., $23.23^{\circ}$ W., 2,301-meter water depth)}

Site 552 is located near the margin of the Hatton-Rockall Basin, just west of Edoras Bank. The PRISM3 mean annual SST for DSDP Hole 552A, located in the central North Atlantic, was estimated to be $16.7^{\circ} \mathrm{C}$ with very high confidence (Dowsett and others, 2012). The chronology developed for Hole 552A was a combination of paleomagnetic (Zimmerman and others, 1985), isotopic (Curry and Miller, 1989), and biostratigraphic (Dowsett and Poore, 1990) data; all Pliocene magnetic reversals were recorded in sediments, and the position of a small hiatus was determined by analyzing the oxygen isotope record (Dowsett and Poore, 1990). SST was estimated at DSDP Hole 552A using multiple proxies: foraminifer transfer function (124 faunal samples ranging from 4.62 to 2.29 Ma [PRISM Project Members, 1996]), Mg/Ca (14 samples of Globigerina bulloides), and alkenone unsaturation ratios (19 samples). Dowsett and Poore (1990) developed quantitative SST estimates based on the planktic foraminifer faunas at this site. Foraminifera were abundant and well preserved, and transfer function communalities were all very high, ranging from 0.894 to 0.991 and averaging 0.958 (Dowsett and Poore, 1990, 1991). All three independent proxy estimates were in good agreement, with alkenone- and $\mathrm{Mg} / \mathrm{Ca}$-based estimates falling between transfer function-derived cold and warm season estimates (Robinson, Dowsett, and others, 2008; Dowsett, Robinson, Stoll, and others, 2010).

\section{DSDP Site 603 (35.49 N., $70.03^{\circ}$ W., 4,633-meter water depth)}

Site 603 is located at the foot of the continental rise approximately $550 \mathrm{~km}$ east of Cape Hatteras, North Carolina, just east of the mean path of the present day Gulf Stream Current. The mean annual SST at DSDP Hole 603C was estimated to be $26.4{ }^{\circ} \mathrm{C}$ with high confidence (Dowsett and others, 2012). Paleomagnetic stratigraphy and planktic foraminifer events were in close agreement and provided a reliable chronology for this site (Canninga and others, 1986). Planktic foraminifera and calcareous nannofossils from Hole 603C were originally investigated by Ma'alouleh and Moullade (1986) and Muza and others (1986), respectively. Census data on planktic foraminifera were from Poore (1991) with 53 samples ranging from 3.29 to $1.60 \mathrm{Ma}$ (PRISM Project Members, 1996). The foraminifer faunas were dissolved through much of the 3.15 to $2.85 \mathrm{Ma}$ interval, which tended to lower SST estimates. SST estimation using a transfer function performed well with an average communality of 0.74 (Dowsett and Poore, 1991).

\section{DSDP Site 606 ( $37.34^{\circ}$ N., $35.50^{\circ}$ W., 3,007-meter water depth)}

Site 606 is located on the upper western flank of the Mid-Atlantic Ridge roughly 260 nautical miles west-southwest of the Azores in the northern part of the present day subtropical gyre. The mean annual SST for DSDP Site 606, located in the central North Atlantic, was estimated to be $21.6^{\circ} \mathrm{C}$ with very high confidence (Dowsett and others, 2012). A stratigraphically continuous sequence of lower Pliocene through Quaternary nannofossil oozes was recovered from Hole 606 (Shipboard Scientific Party, 1983). Abundant, well preserved calcareous nannofossils and planktic and benthic foraminifera were present throughout the section (Backman and Pestiaux, 1986; Takayama and Sato, 1986; Weaver, 1986; Weaver and Clement, 1986; Dowsett, 1989a). Paleomagnetic study of the sediments recovered from Hole 606 showed a complete record of paleomagnetic reversals between the core-top and the bottom of the Cochiti event (Clement and Robinson, 1986). The chronology for Hole 606 was based on the magnetobiochronology developed in Dowsett (1989a). Accumulation rates for Hole 606 average $4.5 \mathrm{~cm} / \mathrm{k}$.y. SST was estimated using multiple proxies: foraminifer transfer function, $\mathrm{Mg} / \mathrm{Ca}$ (30 samples of Globigerinoides ruber), and alkenone unsaturation ratios (29 samples). Dowsett and Poore (1988) developed quantitative SST estimates based on 120 planktic foraminifer samples at this site, ranging from 4.06 to 2.21 Ma (Dowsett and others, 1988; PRISM Project Members, 1996). Transfer function communalities range from 0.36 to 0.84, averaging 0.62 (Dowsett and Poore, 1991). SST estimates from alkenones and $\mathrm{Mg} / \mathrm{Ca}$ are in agreement with transfer function estimates (Robinson, Dowsett, and others, 2008; Dowsett, Robinson, Stoll, and others, 2010).

\section{DSDP Site $607\left(41.00^{\circ}\right.$ N., $32.96^{\circ}$ W., 3,427-meter water depth)}

The mean annual SST for DSDP Site 607, located in the central North Atlantic, was estimated to be $18.9^{\circ} \mathrm{C}$ with very high confidence (Dowsett and others, 2012). In addition to a very good magnetobiochronology at this site (Baldauf and others, 1986), an age model was available from an orbitally tuned marine oxygen isotope record (Lisiecki and Raymo, 2005). SST was estimated at DSDP Site 607 using multiple proxies: foraminifer transfer function, $\mathrm{Mg} / \mathrm{Ca}$ ( 18 samples of Globigerina bulloides), and alkenone unsaturation ratios (18 samples) (Robinson, Dowsett, and others, 2008). Foraminifera were abundant and well preserved (Dowsett and West, 1992) in 31 samples ranging from 3.69 to $2.21 \mathrm{Ma}$ (PRISM Project Members, 1996). Transfer function communalities ranged from 0.63 to 0.91 , averaging 0.81 over the PRISM3 interval (Robinson, Dowsett, and others, 2008). All three independent SST proxy estimates agree well (Robinson, Dowsett, and others, 2008; Dowsett, Robinson, Stoll, and others, 2010). 


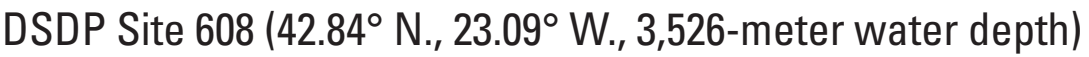

The mean annual SST at DSDP Site 608 was estimated to be $21.7^{\circ} \mathrm{C}$ with very high confidence (Dowsett and others, 2012). The age model at this North Atlantic site was based on integrated magnetobiochronology (Baldauf and others, 1986). Foraminifera were abundant with good preservation in 39 samples ranging from 3.16 to 2.84 Ma (PRISM Project Members, 1996). Application of factor analytic transfer function GSF18 (Dowsett and Poore, 1990; Dowsett, 1991) to these samples resulted in communalities ranging from 0.3 to 0.9 with an average of 0.57 in the PRISM3 interval.

\section{DSDP Site 609 ( $49.88^{\circ}$ N., $24.24^{\circ}$ W., 3,883-meter water depth)}

The mean annual SST for DSDP Site 609 , located in the central North Atlantic, was estimated to be $19.4{ }^{\circ} \mathrm{C}$ with very high confidence (Dowsett and others, 2012). The age model at this site was based on a complete paleomagnetic record across the PRISM3 interval (Baldauf and others, 1986). SST was estimated at DSDP Hole 609B using multiple proxies: foraminifer transfer function, $\mathrm{Mg} / \mathrm{Ca}$ (88 samples of Globigerina bulloides from Bartoli and others, 2005) and alkenone unsaturation ratios (22 samples) (Robinson, Dowsett, and others, 2008). Foraminifera were abundant and well preserved with 34 samples ranging from 4.05 to $2.18 \mathrm{Ma}$ (PRISM Project Members, 1996). Average transfer function communality was 0.66 and ranged from 0.30 to 0.89 (Robinson, Dowsett, and others, 2008). Faunal SSTs were much higher than alkenone- and $\mathrm{Mg} / \mathrm{Ca}$-based estimates; these may have been overestimated because of high abundances of Globorotalia puncticulata and Neogloboquadrina acostaensis (see Robinson, Dowsett, and others, 2008; Dowsett, Robinson, Stoll, and others, 2010). SST estimates from the three proxies were averaged to arrive at a mean annual SST estimate.

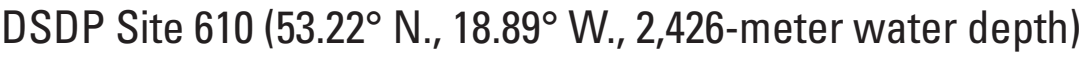

The mean annual SST estimate at DSDP Site 610 in the North Atlantic was estimated to be $19.3^{\circ} \mathrm{C}$ with very high confidence (Dowsett and others, 2012). Original chronology at this site was based on paleomagnetic stratigraphy (Baldauf and others, 1986). An updated chronology was provided by a benthic foraminiferal stable oxygen isotope record tuned to the LR04 benthic foraminiferal isotope stack (Lisiecki and Raymo, 2005) using paleomagnetic reversals as guidelines (De Schepper and others, 2013). Planktic foraminifera were abundant and well preserved in 33 DSDP Hole 610A samples falling between 4.45 and 2.22 Ma (PRISM Project Members, 1996). Applying the factor analytic transfer function GSF18 (Dowsett and Poore, 1990 ; Dowsett, 1991) to these samples resulted in an average communality of 0.88 .

\section{ODP Site 659 (18.08 ${ }^{\circ}$ N., $21.03^{\circ}$ W., 3,072-meter water depth)}

The mean annual SST at ODP Site 659 was estimated to be $25.0^{\circ} \mathrm{C}$ with very high confidence (Dowsett and others, 2012). The age model at ODP Site 659 was based on astronomically tuned chronology (Tiedemann and others, 1994). Planktic foraminifera were abundant and well preserved in 27 Hole 659A samples ranging from 3.36 to 2.90 Ma (Foley and Dowsett, 1992 ; PRISM Project Members, 1996). Applying the factor analytic transfer function GSF18 (Dowsett and Poore, 1990; Dowsett, 1991 ) to these samples resulted in communalities for the PRISM interval of $\geq 0.68$.

\section{ODP Site 661 (9.45 N., $19.39^{\circ}$ W., 4,013-meter water depth)}

The mean annual SST at DSDP Site 661 in the North Atlantic was estimated to be $26.9^{\circ} \mathrm{C}$ with very high confidence (Dowsett and others, 2012). The age model at this site was based on integrated magnetobiostratigraphy (Weaver and others, 1989). Foraminifera were abundant and well preserved in 34 Hole 661 A samples ranging from 3.18 to 2.85 Ma (Dowsett and West, 1992; PRISM Project Members, 1996). Applying the factor analytic transfer function GSF18 (Dowsett and Poore, 1990 ; Dowsett, 1991) to these samples resulted in excellent communalities, with an average of 0.83.

\section{ODP Site 667 (4.55 N., 21.9 W., 3,525-meter water depth)}

Site 667 is located in the eastern equatorial Atlantic at the base of the southeastern margin of the Sierra Leone Rise. The mean annual SST at DSDP Site 667 was estimated to be $27.0^{\circ} \mathrm{C}$ with high confidence (Dowsett and others, 2012). The paleomagnetic stratigraphy at this site was insufficient for age model use; therefore, the chronology was based on a combination of planktic foraminifer and calcareous nannofossil datums (Weaver and others, 1989). Foraminifera were abundant and well preserved in 35 Hole 667A samples ranging from 3.38 to $2.28 \mathrm{Ma}$ (Foley and Dowsett, 1992; PRISM Project Members, 1996). SST estimates were produced using a factor analytic transfer function, resulting in communalities $>0.80$ (Dowsett and Poore, 1991). 


\section{ODP Site 925 (4.20 N., $43.49^{\circ}$ W., 3,041-meter water depth)}

This site was not included in the Dowsett and others (2012) verification dataset. The mean annual SST at this site in the equatorial Atlantic Ocean was estimated to be $27.4{ }^{\circ} \mathrm{C}$ with very high confidence (table 1). The age model at this site was determined by astronomical tuning (Tiedemann and Franz, 1997). Temperature estimation was based on the modern analog technique with SCD values ranging from 0.07 to 0.32 with a mean of 0.16 over 47 planktic foraminifer samples from Holes 925B and 925C ranging from 3.34 to $2.85 \mathrm{Ma}$ (Foley and others, 2015). Foraminifer specimens were abundant and well preserved throughout the PRISM3 interval. SST was also estimated from 95 alkenone samples with concentrations $>0.9$ (Dowsett, Foley, and others, 2017). Alkenone-derived estimates fit the multiproxy model illustrated by Dowsett and Robinson (2007) and were thus included in the mean annual estimate.

\section{ODP Site 951 (32.03 ${ }^{\circ}$ N., $24.87^{\circ}$ W., 5,437-meter water depth)}

Site 951 is located along the western margin of the eastern limb of the North Atlantic subtropical gyre. The mean annual SST at ODP Site 951 was estimated to be $23.5^{\circ} \mathrm{C}$ with very high confidence (Dowsett and others, 2012). The age model at this site was constructed from a complete paleomagnetic record and eight biostratigraphic events in the PRISM3 interval (Lutz, 2011b). Planktic foraminifera from 32 Hole 951A planktic foraminifer samples ranging from 3.30 to 2.96 Ma were abundant and well preserved; assemblage data appear in Lutz (2011b). SST estimates were gained from planktic foraminifer assemblage data using the modern analog technique, $\mathrm{Mg} / \mathrm{Ca}$ (31 samples of Globigerinoides ruber), and alkenones (31 samples; Lutz, 2011a; Dowsett, Foley, and others, 2017). SCD values for samples within the PRISM interval averaged $\leq 0.2$. Mg/Ca- and alkenonederived estimates fall between faunal cold and warm estimates.

\section{ODP Site $958\left(23.99^{\circ}\right.$ N., $20.00^{\circ}$ W., 3,728-meter water depth)}

Site 958 is located in the Canary Current to the west of the African coastal upwelling zone. The mean annual SST at ODP Site 958 was estimated to be $24.0^{\circ} \mathrm{C}$ with very high confidence (Dowsett and others, 2012). The age model at this site was constructed from a complete paleomagnetic record and eight biostratigraphic events in the PRISM3 interval (Lutz, 2011b). Planktic foraminifera were abundant and well preserved in 34 Hole 958A samples ranging from 3.30 to $2.97 \mathrm{Ma}$; assemblage data appear in Lutz (2011b). SST estimates were gained from planktic foraminifer assemblage data using the modern analog technique, $\mathrm{Mg} / \mathrm{Ca}$ (33 samples of Globigerinoides ruber), and alkenones (34 samples; Lutz, 2011a; Dowsett, Foley, and others, 2017). SCD values for samples within the PRISM interval averaged $\leq 0.2 . \mathrm{Mg} / \mathrm{Ca}$ - and alkenone-derived estimates fall between faunal cold and warm estimates.

\section{ODP Site 1006 (24.44 N., $79.46^{\circ}$ W., 658-meter water depth)}

Site 1006 is located in the Florida Current segment of the Gulf Stream, between Florida and Cuba. The mean annual SST at ODP Site 1006 was estimated to be $27.9^{\circ} \mathrm{C}$ with high confidence (Dowsett and others, 2012). The age model at this site was constructed from nine biostratigraphic events in the PRISM3 interval (Lutz, 2011b), based on detailed biochronologic dating (Wright and Kroon, 2000) coupled with cyclostratigraphy (Kroon and others, 2000). Planktic foraminifera were abundant and well preserved in 34 Hole 1006A samples ranging from 3.30 to $2.97 \mathrm{Ma}$; assemblage data appear in Lutz (2011b). SST estimates were gained from planktic foraminifer assemblage data using the modern analog technique, $\mathrm{Mg} / \mathrm{Ca}$ (32 samples of Globigerinoides ruber; Lutz, 2011a,b), and alkenones (6 samples; Dowsett, Foley, and others, 2017). SCD values for samples within the PRISM3 interval averaged $\leq 0.2 . \mathrm{Mg} / \mathrm{Ca}$-derived estimates fall between faunal cold and warm estimates.

\section{ODP Site 1062 (28.25 N., $74.46^{\circ}$ W., 658-meter water depth)}

Site 1062 is located $\sim 650 \mathrm{~km}$ east of Florida along the eastern fringes of the southwestern sector of the Gulf Stream. The mean annual SST at ODP Site 1062 was estimated to be $27.2^{\circ} \mathrm{C}$ with very high confidence (Dowsett and others, 2012). The age model at this site was constructed from a complete paleomagnetic record and six biostratigraphic events in the PRISM3 interval (Lutz, 2011b). Planktic foraminifera were abundant and well preserved in 34 Hole 1062B samples ranging from 3.30 to $2.97 \mathrm{Ma}$; assemblage data appear in Lutz (2011b). SST estimates were gained from planktic foraminifer assemblage data using the modern analog technique, $\mathrm{Mg} / \mathrm{Ca}$ (from Globigerinoides ruber in 31 samples; Lutz, 2011a,b), and alkenones (83 samples; Dowsett, Foley, and others, 2017). SCD values for samples within the PRISM interval averaged $\leq 0.2 . \mathrm{Mg} / \mathrm{Ca}$-derived estimates fall between faunal cold and warm estimates. 


\section{ODP Site $1063\left(33.69^{\circ}\right.$ N., $57.61^{\circ}$ W., 4,584-meter water depth)}

Site 1063 is located at the southern margin of the northern limb of the North Atlantic subtropical gyre. The mean annual SST at ODP Site 1063 was estimated to be $23.8^{\circ} \mathrm{C}$ with very high confidence (Dowsett and others, 2012). The age model at this site was constructed from a complete paleomagnetic record and seven biostratigraphic events in the PRISM3 interval (Lutz, 2011b). Planktic foraminifera were abundant and well preserved in 31 Hole 1063A samples ranging from 3.30 to $2.97 \mathrm{Ma}$; assemblage data appear in Lutz (2011b). SST estimates were gained from planktic foraminifer assemblage data using the modern analog technique and from alkenones (23 samples; Lutz, 2011a; Dowsett, Foley, and others, 2017). SCD values for samples within the PRISM3 interval averaged $\leq 0.2$. The alkenone-derived estimate is slightly cooler than the faunal cold season estimate (Lutz, 2011a).

\section{Cayo Aqua $\left(9.15^{\circ}\right.$ N., $82.05^{\circ}$ W., 0.0-meter water depth)}

The Cayo Agua Formation records part of the Pliocene paleoceanographic history of northwestern Panama and Costa Rica. The mean annual SST at Cayo Aqua in the Caribbean Sea was estimated to be $28.8^{\circ} \mathrm{C}$ with medium confidence (Dowsett and others, 2012). The upper part of the Cayo Aqua Formation has been dated at 3.5 to 2.9 Ma by calcareous nannofossils and planktic foraminifera (Cotton and Dowsett, 1990). The age model was constructed from planktic foraminifer, calcareous nannofossil, and paleomagnetic stratigraphy using graphic correlation. Paleotemperature was estimated from an ostracod factor analytic transfer function (Cronin and Dowsett, 1990) with communalities ranging from 0.46 to 0.77 . Ostracods were abundant and well preserved in 12 samples (Cronin, 1991b).

\section{SEFlor (G-182) (25.78 N., $80.28^{\circ}$ W., 0.0-meter water depth)}

The mean annual SST at this southeast Florida site was estimated to be $25.7^{\circ} \mathrm{C}$ with medium confidence (Dowsett and others, 2012). The age model at this site was determined from planktic foraminifer and calcareous nannofossil biostratigraphy (Cronin, 1991b). Pliocene temperature was estimated from one sample containing abundant and well preserved ostracods using a factor analytic transfer function equation developed by Cronin and Dowsett (1990) using modern ostracods. The communality of the single sample was 0.46 (Cronin, 1991b).

\section{Pinecrest Beds (27.35 N., $82.43^{\circ}$ W., 0.0-meter water depth)}

The Pinecrest Formation occurs along the southeast Florida peninsula. The mean annual SST at this site was estimated to be $24.9^{\circ} \mathrm{C}$ with medium confidence (Dowsett and others, 2012). Early to middle Pliocene age was assigned to these samples based on planktic foraminifera and ostracod assemblage zones (Cronin, 1991b). Pliocene temperature was estimated from four samples containing abundant and well preserved ostracods using a factor analytic transfer function equation developed by Cronin and Dowsett (1990) using modern ostracods. Communalities ranged from 0.51 to 0.87 (Cronin, 1991b).

\section{Sarasota $\left(27.25^{\circ}\right.$ N., $82.66^{\circ}$ W., 0.0 -meter water depth)}

This is a second site along the Pinecrest Formation. The mean annual SST at this western Florida site was estimated to be $23.4{ }^{\circ} \mathrm{C}$ with high confidence (Dowsett and others, 2012). The age range of 3.5 to 3.0 Ma was determined for these samples from calcareous nannofossil and ostracod biostratigraphy, strontium ratios obtained on mollusks, and paleomagnetic records (Cronin, 1991b). Pliocene temperature was estimated from five samples containing abundant and well preserved ostracods using a factor analytic transfer function equation developed by Cronin and Dowsett (1990) using modern ostracods. Communalities ranged from 0.54 to 0.76 (Cronin, 1991b).

\section{Duplin $\left(34.00^{\circ}\right.$ N., $79.00^{\circ}$ W., $0.0-$ meter water depth)}

The Duplin Formation of southeastern and northeastern North Carolina represents the marine transgression that occupied the Orangeburg Scarp (Dowsett and Cronin, 1990). The mean annual SST at this site was estimated to be $23.9^{\circ} \mathrm{C}$ with $h i g h$ confidence (Dowsett and others, 2012). The age range of 3.5 to 3.0 Ma was determined from planktic foraminifer, ostracod, and calcareous nannofossil biostratigraphy. Pliocene temperature was estimated from nine samples containing abundant and well preserved ostracods using a factor analytic transfer function equation developed by Cronin and Dowsett (1990) using modern ostracods. Communalities ranged from 0.46 to 0.77 (Cronin, 1991b). 


\section{Lee Creek $\left(35.38^{\circ}\right.$ N., $76.75^{\circ}$ W., 0.0 -meter water depth)}

Deposits of the Yorktown Formation are exposed at Lee Creek Mine in North Carolina. The mean annual SST at this site was estimated to be $23.5^{\circ} \mathrm{C}$ with high confidence (Dowsett and others, 2012). The age range of 4.5 to 3.0 Ma was developed from planktic foraminifer, ostracod, and calcareous nannofossil biostratigraphy and paleomagnetic records. Pliocene temperature was estimated from eight samples containing abundant and well preserved ostracods using a factor analytic transfer function equation developed by Cronin and Dowsett (1990) using modern ostracods. Communalities ranged from 0.60 to 0.73 (Cronin, 1991b).

\section{Yorktown $\left(37.00^{\circ}\right.$ N., $76.50^{\circ}$ W., $0.0-$ meter water depth)}

The Yorktown Formation is an unconformity-bounded package of fine-grained sandy clays and shell marls exposed along the Atlantic Coastal Plain from Virginia to North Carolina. The mean annual SST at this site along the Virginia coast was estimated to be $21.5^{\circ} \mathrm{C}$ with high confidence (Dowsett and others, 2012). Graphic correlation using biostratigraphy and paleomagnetics and tuned to a sea level cycle determined an age range of 3.8 to 2.9 Ma for the Yorktown Formation (Cronin, 1991b). Twenty-three abundant and well preserved planktic foraminifer samples from six Yorktown Formation localities were collected (Dowsett and Wiggs, 1992). These samples were primarily from the upper part of the Morgarts Beach Member of the Yorktown formation dated at 3.4 and 3.0 Ma (see Krantz, 1991). Quantitative estimates of SST were based on a factor analytic transfer function applied to planktic foraminifer assemblages from three sites with communalities of 0.73 to 0.80 (Dowsett and Poore, 1991). The ostracod age model at this site was developed from planktic foraminifer, ostracod, and calcareous nannofossil biostratigraphy and paleomagnetic records. Pliocene temperature was estimated from eight samples containing abundant and well preserved ostracods using a factor analytic transfer function developed by Cronin and Dowsett (1990). Ostracod communalities ranged from 0.58 to 0.73 (Cronin, 1991b).

\section{South Atlantic Ocean, Gulf of Mexico, and Mediterranean Sea}

The few sites in the South Atlantic Ocean, the Gulf of Mexico, and the Mediterranean Sea are grouped together because they do not fall in any of the other geographic categories.

\section{DSDP Site 516 (30.27 $7^{\circ} ., 35.28^{\circ}$ W., 1,313-meter water depth)}

Site 516 lies on the Rio Grande Rise in the South Atlantic Ocean. The mean annual SST at DSDP Site 516 was estimated to be $23.3^{\circ} \mathrm{C}$ with high confidence (Dowsett and others, 2012). The age model at this South Atlantic site was based on graphic correlation of foraminifer, nannofossil, and paleomagnetic stratigraphic events (Dowsett, 1989a). Planktic foraminifera were abundant and well preserved in 26 Hole 516A samples ranging from 3.49 to $2.05 \mathrm{Ma}$. Applying the factor analytic transfer function GSF18 (Dowsett, 1991; Dowsett and Poore, 1990) to these samples resulted in sample communalities ranging from 0.3 to 0.9 with an average of 0.51 .

\section{DSDP Site 521 (26.07 S., $10.27^{\circ}$ W., 4,128-meter water depth)}

The mean annual SST at DSDP Site 521 was estimated to be $24.1^{\circ} \mathrm{C}$ with medium confidence (Dowsett and others, 2012). The age model at this South Atlantic site was based on graphic correlation of foraminifer, nannofossil and paleomagnetic stratigraphic events (Dowsett, 1989a). Planktic foraminifera are abundant and well preserved in 21 samples ranging from 3.23 to $2.89 \mathrm{Ma}$. SST estimates (Dowsett and others, 1996) were calculated using the modern analog technique outlined in Dowsett and Robinson (1998) using samples with SCD values $\leq 0.2$.

\section{DSDP Site 532 ( $19.74^{\circ}$ S., $10.52^{\circ}$ E., 1,331-meter water depth)}

Site 532 is located on the continental margin of Southwest Africa near the easternmost end of the Walvis Ridge and in the path of the Benguela Current. The mean annual SST at DSDP Site 532 was estimated to be $20.1{ }^{\circ} \mathrm{C}$ with medium confidence (Dowsett and others, 2012). Chronology at this southeast Atlantic site was based on graphic correlation of magnetostratigraphic and biostratigraphic events (Dowsett, 1989b) and the correlation of an oxygen isotope record to that of DSDP Site 607 (Dowsett and others, 1996). Foraminifera from 68 Pliocene samples (28 samples between 3.7 and $2.5 \mathrm{Ma}$ ) ranged from few to common, and preservation was poor to good (Dowsett, 1989b; Dowsett and Willard, 1996). SST estimates for DSDP 532 were attained by semiquantitative analysis and comparison of Pliocene and modern assemblages in the region (Dowsett and others, 1996; Dowsett and Willard, 1996). 


\section{ODP Site 704 (46.88 S., $7.42^{\circ}$ E., 2,532-meter water depth)}

The mean annual SST at ODP Site 704, located in the southeast Atlantic Ocean, was estimated to be $8.4{ }^{\circ} \mathrm{C}$ with very high confidence (Dowsett and others, 2012). The age model at this site was based on isotopic and paleomagnetic stratigraphy (Hodell and Venz, 1992). SST estimates were based on foraminiferal assemblages using the modern analog technique with good (average SCD $=0.13$ ) results (Dowsett, 1996). Foraminifera were abundant and well preserved (Dowsett and others, 1993), and 62 Hole 704A samples ranged from 3.44 to $2.73 \mathrm{Ma}$.

\section{ODP Site 625 (28.83 N., 87.17 W., 889-meter water depth)}

Site 625 is located on the west Florida continental slope in the Gulf of Mexico. The mean annual SST estimate of $25.0^{\circ} \mathrm{C}$, with high confidence, was based on alkenone paleothermometry (Dowsett and others, 2012). A nearly complete Pliocene and Quaternary record was recovered at this site with abundant and well preserved planktic foraminifera (Joyce and others, 1990). Twenty-six alkenone samples from Hole 625B range in age from 3.33 to 2.92 Ma using the age model of Joyce and others (1990) based on six biostratigraphic events (Dowsett, Foley, and others, 2017).

\section{DSDP Site 132 (40.25 N., $11.43^{\circ}$ E., 2,835-meter water depth)}

The mean annual SST at DSDP 132 in the Mediterranean Sea was estimated to be $21.0^{\circ} \mathrm{C}$ with high confidence (Dowsett and others, 2012). The age model at this site was based on chronology developed from planktic foraminifer biostratigraphy. Six samples ranging from 3.35 to 3.0 Ma contained foraminifera that were abundant and well preserved (Thunell, 1979). SST estimates from Site 132 were calculated using a factor analytic transfer function with sample communalities ranging from 0.65 to 0.78; SST estimates first appeared in Dowsett and others (1999).

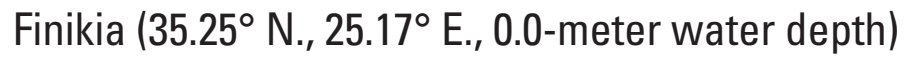

The mean annual SST at this site was estimated to be $18.0^{\circ} \mathrm{C}$ with high confidence (Dowsett and others, 2012). The age model at this site was based on indepth biostratigraphic study of Mediterranean Pliocene planktic foraminiferal zones and foraminifer assemblage data in Spaak (1983). Planktic foraminifera were abundant and well preserved. PRISM workers used these counts (57 mid-Piacenzian samples) to estimate SST from a factor analytic transfer function; these SST estimates first appeared in Dowsett and others (1999). Applying the factor analytic transfer function GSF18 (Dowsett and Poore, 1990; Dowsett, 1991) to these samples resulted in communalities averaging 0.80 .

\section{Punta di Maiata $\left(37.33^{\circ}\right.$ N., $13.50^{\circ}$ E., 0.0 -meter water depth)}

The mean annual SST at this site was estimated to be $19.4{ }^{\circ} \mathrm{C}$ with high confidence (Dowsett and others, 2012). The age model at this site was based on indepth biostratigraphic study of Mediterranean Pliocene planktic foraminiferal zones and foraminifer assemblage data in Spaak (1983). Planktic foraminifera were abundant and well preserved. PRISM workers used these counts (47 mid-Piacenzian samples) to estimate SST from a factor analytic transfer function; these SST estimates first appeared in Dowsett and others (1999). Applying the factor analytic transfer function GSF18 (Dowsett and Poore, 1990; Dowsett, 1991) to these samples resulted in communalities averaging 0.80 .

\section{Punta Piccola $\left(37.33^{\circ}\right.$ N., $13.58^{\circ}$ E., 0.0 -meter water depth)}

The mean annual SST at this site was estimated to be $21.4^{\circ} \mathrm{C}$ with high confidence (Dowsett and others, 2012). The age model at this site was based on indepth biostratigraphic study of Mediterranean Pliocene planktic foraminiferal zones and foraminifer assemblage data in Spaak (1983). Planktic foraminifera were abundant and well preserved. PRISM workers used these counts (41 mid-Piacenzian samples) to estimate SST from a factor analytic transfer function; these SST estimates first appeared in Dowsett and others (1999). Applying the factor analytic transfer function GSF18 (Dowsett and Poore, 1990; Dowsett, 1991) to these samples resulted in communalities range from 0.63 to 0.92 . The use of a single taxonomic category for Neogloboquadrina by Spaak (1983), as well as a greater influence than we find elsewhere by factors other than temperature on assemblage composition, resulted in skewed temperature interpretations for this site. 


\section{Pacific Ocean}

Unless indicated otherwise, foraminifer assemblage-based SST estimates at the Pacific Ocean sites use a variant of the modern analog technique (see Dowsett and Robinson, 1998; Dowsett, 2007).

\section{DSDP Site $36\left(40.98^{\circ}\right.$ N., $130.12^{\circ}$ W., 3,273-meter water depth)}

The mean annual SST at this site in the northeastern Pacific Ocean was estimated to be $16.8{ }^{\circ} \mathrm{C}$ with medium confidence (Dowsett and others, 2012). Chronology at Site 36 was based on two radiometrically dated ash beds and planktic foraminifer biostratigraphy (Poore, 1999). Foraminifera were abundant but strongly dissolved in 18 samples ranging from 3.2 to 2.2 Ma. Semiquantitative estimates of SST were based on comparison of assemblages to assemblages recovered at DSDP sites 173 and 310 .

\section{DSDP Site 310 (36.87 ${ }^{\circ}$., $176.90^{\circ}$ W., 3,516-meter water depth)}

DSDP Site 310 is located on the Hess Rise beneath the interface of subtropical and temperate-to-subarctic water masses (Keller, 1978). The mean annual SST at DSDP Site 310 in the central North Pacific Ocean was estimated to be $21.6^{\circ} \mathrm{C}$ with medium confidence (Dowsett and others, 2012). The age model at this site was determined from integrated foraminifer, radiolarian, and diatom magnetobiostratigraphy (Keller, 1978). Foraminifer preservation was variable, and specimens were abundant in all 136 samples ranging from 3.205 to $1.603 \mathrm{Ma}$ (original census data from 71 Pliocene to Pleistocene samples appear in Keller, 1978). MAT estimates were based upon samples with SCD values ranging from 0.24 to 0.09 .

\section{DSDP Site 445 (25.52 $2^{\circ}$., $133.20^{\circ}$ E., 3,377-meter water depth)}

Site 445 is located on the Daito Ridge in the northern Philippine Sea. The mean annual SST at ODP Site 445 in the western Pacific Ocean was estimated to be $26.2^{\circ} \mathrm{C}$ with high confidence (Dowsett and others, 2012). The age model at this site was based on graphic correlation of Dowsett (1989a,b). Planktic foraminifera were abundant in 23 samples between 3.82 and 2.56 Ma, but some samples show high fragmentation from dissolution (Dowsett and West, 1993; Dowsett and Robinson, 1998). Modern analog technique SST estimates carry SCD values ranging from 0.19 to 0.51 with a mean of 0.27 (Dowsett and Robinson, 1998). Mg/Ca analysis of Globigerinoides ruber and Globigerinoides sacculifer from these same samples yielded SST estimates in good agreement with faunal-based estimates (Dowsett, Robinson, Stoll, and others, 2010).

\section{DSDP Site $573\left(0.48^{\circ}\right.$ N., $133.3^{\circ}$ W., 4,301-meter water depth)}

Site 573 is located just north of the equator in the central Pacific Ocean. The mean annual SST at DSDP Site 573 was estimated to be $24.7^{\circ} \mathrm{C}$ with high confidence (Dowsett and others, 2012). The age model at this site was based on magnetobiochronology (Dowsett, 1989a), and SST estimates were based on a quantitative analysis of radiolarian assemblages in 18 samples ranging from 3.15 to 2.9 Ma (Hays and others, 1989). Communalities from the factor analytic transfer function exceeded 0.8 . Foraminifera were common, but dissolution may have concentrated solution resistant forms (Dowsett, 1989a). Radiolaria were abundant and well preserved (Hays and others, 1989).

\section{DSDP Site 579 ( $38.63^{\circ}$ N., $153.84^{\circ}$ E., 5,737-meter water depth)}

The mean annual SST at DSDP Site 579 in the Northwest Pacific Ocean was estimated to be $22.6{ }^{\circ} \mathrm{C}$ with very high confidence (Dowsett and others, 2012). The age model at this site was based on paleomagnetic stratigraphy and diatom biostratigraphy (Bleil, 1985; Koizumi, 1985). Quantitative SST estimates from diatom paleoclimate curves were based on cold- and warm-water taxa ratios from six samples between 3.3 and 3.0 Ma (Koizumi, 1985; Koizumi and Tanimura, 1985, reinterpreted by Barron, 1992). Diatoms in these samples ( $>50$ percent extant species) were abundant with excellent preservation (Koizumi, 1985). 


\section{DSDP Site 580 ( $41.63^{\circ}$ N., $153.98^{\circ}$ E., 5,375-meter water depth)}

The mean annual SST at DSDP Site 580 in the Northwest Pacific Ocean was estimated to be $17.7^{\circ} \mathrm{C}$ with very high confidence (Dowsett and others, 2012). Chronology was based on paleomagnetic stratigraphy and diatom biostratigraphy (Bleil, 1985; Koizumi, 1985). Quantitative SST estimates from diatom paleoclimate curves were based on cold- and warm-water taxa ratios from 47 samples ranging from 3.25 to $2.55 \mathrm{Ma}$; communalities were typically $>0.9$ (Barron, 1992, 1995). Diatoms in these samples are abundant with excellent preservation (Koizumi, 1985).

\section{DSDP Site $586\left(0.48^{\circ}\right.$ S., $158.48^{\circ}$ E., 2,207-meter water depth)}

The mean annual SST at ODP Site 586 in the western equatorial Pacific Ocean was estimated to be $29.1^{\circ} \mathrm{C}$ with medium confidence (Dowsett and others, 2012). The age model at this site was based on graphic correlation (Dowsett, 1988). A semiquantitative SST estimate was formulated from six foraminifer samples that fall within the PRISM3 interval (Jenkins, 1992a,b). Planktic foraminifera are abundant and well preserved.

\section{DSDP Site 592 (36.47º S., $165.44^{\circ}$ E., 1,088-meter water depth)}

The mean annual SST at this site in the Southwest Pacific Ocean was estimated to be $19.7^{\circ} \mathrm{C}$ with very high confidence (Dowsett and others, 2012). Chronology at DSDP 592 was based on graphic correlation of magnetostratigraphic and biostratigraphic events (Dowsett, 1988). Planktic foraminifera were abundant and well preserved in 68 samples ranging in age from 3.3 to $2.43 \mathrm{Ma}$. SST estimates were based on the modern analog technique and resulted in low $(\leq 0.16)$ SCD values (Robinson and Dowsett, 1996).

\section{ODP Site 677 (1.12 N., 83.44 W., 3,461-meter water depth)}

ODP Site 677 is located in the Panama Basin, due west of Ecuador. The mean annual SST at ODP Site 677 in the eastern equatorial Pacific Ocean was estimated to be $27.8^{\circ} \mathrm{C}$ with high confidence (Dowsett and others, 2012). The age model at this site was based on an integrated biochronology (Shipboard Scientific Party, 1988d; Jenkins and Houghton, 1989). Raw data from 14 Hole 677A faunal samples and 89 alkenone samples are found in Robinson, Caballero, and others (2008). Additional faunal samples were later analyzed. Foraminifer specimens were abundant and well preserved. SST was estimated from 27 alkenone samples ranging from 3.29 to $2.98 \mathrm{Ma}$ and 28 faunal samples ranging from 3.31 to $2.95 \mathrm{Ma}$. The modern analog technique worked well with the average SCD equal to 0.26. Modern analog and alkenone SST estimates were in good agreement (Dowsett and Robinson, 2009).

\section{ODP Site $769 B\left(8.78^{\circ}\right.$ N., $121.28^{\circ}$ E., 3,640-meter water depth)}

Site 769 is located on the southeastern flank of the Cagayan Ridge in the Sulu Sea. The mean annual SST at ODP Site 769 in the western equatorial Pacific Ocean was estimated to be $28.1^{\circ} \mathrm{C}$ with medium confidence (Dowsett and others, 2012). The age model at this site was based on incomplete paleomagnetic stratigraphy (Shipboard Scientific Party, 1990b). Twenty-six samples range in age from 5.3 to $2.3 \mathrm{Ma}$; the five samples in the PRISM interval show severely dissolved foraminifera in low abundance (Polanco and Dowsett, 1993; Dowsett and Robinson, 1998). The modern analog technique SST estimate was good with SCD $<0.26$ but showed effects of dissolution (Dowsett and Robinson, 1998).

\section{ODP Site 806 (0.32 N., $159.35^{\circ}$ E., 2,520-meter water depth)}

The mean annual SST at ODP Site 806 in the western equatorial Pacific Ocean was estimated to be $29.1^{\circ} \mathrm{C}$ with very high confidence (Dowsett and others, 2012). Site 806, located on the Ontong Java Plateau, is used to monitor conditions in the western equatorial Pacific because excellent age control is available at this site. The age model was based on biochronology orbitally tuned to an isotopic record (Berger and others, 1993; Jansen and others, 1993). Foraminifera were abundant and well preserved in 86 samples ranging from 3.30 to $3.00 \mathrm{Ma}$ (a subset of 293 samples between 3.88 and $2.53 \mathrm{Ma}$ ) that were used to estimate SST by the modern analog technique (Andersson, 1997; Dowsett, 2007). SST estimates were derived from samples with SCD values $<0.1$ (Dowsett, 2007). Thirty-six Globigerinoides sacculifer samples in the 3.30 to $3.00 \mathrm{Ma}$ age range were examined for $\mathrm{Mg} / \mathrm{Ca}$ SST estimation (Wara and others, 2005). Both proxy estimates were in good agreement (Dowsett and Robinson, 2009). 


\section{ODP Site 847 (0.18 N., $95.32^{\circ}$ W., 3,335-meter water depth)}

The mean annual SST at ODP Site 847 in the eastern equatorial Pacific Ocean was estimated to be $27.1^{\circ} \mathrm{C}$ with very high confidence (Dowsett and others, 2012). Age designations of these samples were based on magnetobiochronology and a gamma-ray attenuation porosity evaluation (GRAPE) tuned age model (Shackleton and others, 1995). Twenty-five Hole 847C foraminifer samples range from 3.31 to $2.96 \mathrm{Ma}$ (Dowsett and Caballero, 2007). Previously published alkenone data (seven samples from 3.32 to $2.90 \mathrm{Ma}$ ) from Dekens and others (2007) and $\mathrm{Mg} / \mathrm{Ca}$ data (19 samples of Globigerinoides sacculifer from 3.30 to $2.96 \mathrm{Ma}$ ) from Wara and others (2005) are incorporated into our SST estimate for this site. MAT faunal estimates were good (SCD $\leq 0.2$ ), and all three SST estimates were in excellent agreement (Dowsett and Robinson, 2009).

\section{ODP Site $852\left(5.28^{\circ}\right.$ N., $110.07^{\circ}$ W., 3,860-meter water depth)}

The mean annual SST at ODP Site 852 in the eastern equatorial Pacific Ocean was estimated to be $29.4{ }^{\circ} \mathrm{C}$ with very high confidence (Dowsett and others, 2012). The age model at was based upon magnetobiochronology and was orbitally tuned (Shackleton and others, 1995). Faunal-based SST estimates performed on 12 Hole 852B samples between 3.8 and 2.8 Ma using the modern analog technique were good with $\mathrm{SCD} \leq 0.2$ (Dowsett and Robinson, 2009). Planktic foraminifera were common but often poorly preserved.

\section{ODP Site 881 (47.10 N., 161.49 E., 5,531-meter water depth)}

The mean annual SST at ODP Site 881 in the Northwest Pacific Ocean was estimated to be $10.1{ }^{\circ} \mathrm{C}$ with very high confidence (Dowsett and others, 2012). Chronology at this site was based on correlation to magnetostratigraphy of Hole 881D (Shipboard Scientific Party, 1993a; Barron and Gladenkov, 1995). Quantitative SST estimates were derived from diatom paleoclimate ratios incorporating a mix of extinct and extant species, applied to 30 samples between 3.40 and 3.09 Ma. Diatoms were abundant with good preservation (Barron, 1995).

\section{ODP Site $883\left(51.20^{\circ}\right.$ N., $167.77^{\circ}$ E., 2,391-meter water depth)}

ODP Site 883 is located on the edge of the Detroit Seamount in the subarctic North Pacific. The mean annual SST at ODP Holes $883 \mathrm{~B}$ and $883 \mathrm{C}$ was estimated to be $9.1^{\circ} \mathrm{C}$ with high confidence (Dowsett and others, 2012). The age model at this site was based on diatom and radiolarian biostratigraphy and magnetostratigraphy (Shipboard Scientific Party, 1993b; Barron and Gladenkov, 1995). Foraminifer preservation ranged from fair to good, and foraminifera were generally abundant; diatoms were abundant with good to excellent preservation (Barron and Gladenkov, 1995). Quantitative SST estimates were derived from (1) diatom paleoclimate ratios incorporating a mix of extinct and extant species, applied to 57 samples between 3.30 and 3.09 Ma (Barron, 1995) and (2) semiquantitative comparison of foraminifera (49 samples) to Pleistocene assemblages (Dowsett and Ishman, 1995). Alkenone based SST estimates were obtained from 19 samples (Dowsett, Foley, and others, 2017).

\section{ODP Site 887 (54.37 N., $148.45^{\circ}$ W., 3,634-meter water depth)}

ODP Site 887 is located on the eastern part of the Patton-Murray Seamount group in the Gulf of Alaska. The mean annual SST at ODP Holes 887A and 887C in the Northeast Pacific Ocean was estimated to be $9.7^{\circ} \mathrm{C}$ with high confidence (Dowsett and others, 2012). Chronology at this site was based on a complete magnetostratigraphic record (Shipboard Scientific Party, 1993c) combined with diatom biostratigraphy (Barron and Gladenkov, 1995). Foraminifer preservation was good, and foraminifera were generally abundant in 63 samples between 3.8 and 2.8 Ma. SST estimates were based on a semiquantitative comparison of foraminifera to Pleistocene assemblages (Dowsett and Ishman, 1995). Alkenone SST estimates were obtained from 12 samples (Dowsett, Foley, and others, 2017).

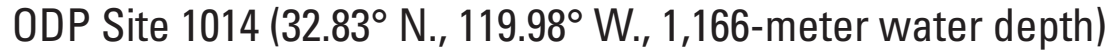

The mean annual SST at ODP Site 1014 in the eastern North Pacific Ocean was estimated to be $23.8^{\circ} \mathrm{C}$ with very high confidence (Dowsett and others, 2012). The ages of samples were determined using an oxygen isotope and magnetic susceptibility tuned age model (Ravelo and others, 2004). The alkenone-based SST estimates (Dowsett and Robinson, 2009) were from 13 samples between 3.29 and 3.04 Ma from Dekens and others (2007). 


\section{ODP Site 1018 (36.98 N., $123.28^{\circ}$ W., 2,477-meter water depth)}

This site was not included in the Dowsett and others (2012) verification dataset. The mean annual SST at this site along the California margin was estimated to be $15.3^{\circ} \mathrm{C}$ with very high confidence (table 1). The age model was determined by biostratigraphy (three nannofossil datums) from Kucera and Kennett (2000). Temperature estimation was based on 30 Hole 1018A alkenone samples ranging in age from 3.31 to $2.96 \mathrm{Ma}$ with $\mathrm{U}^{\mathrm{k}^{\prime}}{ }_{37}$ concentrations $>0.5 \mu \mathrm{g} / \mathrm{g}$ (Dowsett, Foley, and others, 2017). Faunal analysis of the same 30 samples yielded low abundance, often too low for statistical analyses, and an overwhelming dominance of Neogloboquadrina pachyderma and Neogloboquadrina atlantica (Foley and others, 2015).

\section{ODP Site 1021 (39.09 N., $127.78^{\circ}$ W., 4,213-meter water depth)}

Site 1021 lies $360 \mathrm{~km}$ west of the California coast at the seaward margin of the California Current. The mean annual SST at ODP Site1021 in the eastern North Pacific Ocean was estimated to be $20.3{ }^{\circ} \mathrm{C}$ with high confidence (Dowsett and others, 2012). The Hole $1021 \mathrm{C}$ age model was based on magnetic stratigraphy and assumed a linear accumulation rate (Dowsett and Poore, 2000). Foraminifera were abundant, but dissolution was strong throughout Core 10, skewing the foraminifer fauna toward dissolution resistant forms. Modern analog technique SST estimates from 10 foraminifer samples ranging in age from 2.73 to $2.68 \mathrm{Ma}$ were good, with minimum SCD ranging from 0.23 to 0.31 .

\section{ODP Site $1115\left(9.18^{\circ}\right.$ S., $151.57^{\circ}$ E., 1,149-meter water depth)}

Site 1115 is located in the Solomon Sea, just east of the Papuan Peninsula of Papua, New Guinea. The mean annual SST at ODP Site 1115 in the western equatorial Pacific Ocean was estimated to be $28.3{ }^{\circ} \mathrm{C}$ with very high confidence (Dowsett and others, 2012). The age model at this site was based on biochronology, magnetic stratigraphy, and radiometric dating (Siesser, 2001). Foraminifera were well preserved and abundant. Foraminifera and alkenones in 23 Hole 1115B samples ranging in age from 3.33 to $2.94 \mathrm{Ma}$ were used to estimate SST (Stoll, 2010). The modern analog technique worked very well with 21 faunal samples returning modern analogs with $\mathrm{SCD}<0.16$. SST estimates were in agreement between the two methods, though alkenone samples may be near saturation.

\section{ODP Site 1125 (42.55 S., $178.17^{\circ}$ W., 1,365-meter water depth)}

This site was not included in the Dowsett and others (2012) verification dataset. Site 1125 is located $610 \mathrm{~km}$ east of New Zealand's South Island on the Chatham Rise. The mean annual SST at this site was estimated to be $19.6^{\circ} \mathrm{C}$ with high confidence (table 1). The age model was constructed using a combination of micropaleontology and tephra-stratigraphy tied to the magnetostratigraphically well constrained and orbitally tuned sequence in nearby Site 1123 (Carter and others, 1999; Hall and others, 2001). Temperature estimation was based on the modern analog technique using planktic foraminifera with a mean dissimilarity of 0.23 over 14 samples and 29 alkenone samples in the 3.36 to 2.96 Ma interval (Dowsett, Foley, and others, 2017). Planktic foraminifer assemblage data published in Sabaa and others (2004) were reanalyzed for SST analysis in Dowsett and Robinson (2009). Specimens were abundant and well preserved in 72 planktic foraminifer samples ranging from 4.00 to 2.37 Ma.

\section{ODP Site 1236 ( $21.37^{\circ}$ S., $81.43^{\circ}$ W., 1,324-meter water depth)}

This site was not included in the Dowsett and others (2012) verification dataset. Site 1236 is located atop the Nazca Ridge near Easter Island. The mean annual SST at this site along the Peru margin was estimated to be $25.4{ }^{\circ} \mathrm{C}$ with high confidence (table 1). The age model at this site was determined using biostratigraphy of four nannofossil datums (Shipboard Scientific Party, 2003) and an orbitally tuned oxygen isotope age model (Tiedemann and others, 2007). Temperature estimation was based on the modern analog technique using planktic foraminifera with a squared chord distance cutoff of 0.32 from 10 Hole 1236A samples between 3.23 and $2.95 \mathrm{Ma}$. Specimens were abundant and well preserved.

\section{ODP Site $1237\left(16.00^{\circ}\right.$ S., $76.37^{\circ}$ W., 3,212-meter water depth)}

The mean annual SST at ODP Site 1237 in the eastern South Pacific Ocean was estimated to be $25.1{ }^{\circ} \mathrm{C}$ with very high confidence (Dowsett and others, 2012). An orbitally tuned oxygen isotope age model provided age control (Tiedemann and others, 2007). SST estimates were calculated from foraminifer data from 19 Hole $1237 \mathrm{C}$ samples ranging from 3.42 to $2.93 \mathrm{Ma}$ (Caballero and Dowsett, 2008), alkenone data from 21 samples ranging from 3.28 to $2.96 \mathrm{Ma}$ (Dekens and others, 2007), and 
$\mathrm{Mg} / \mathrm{Ca}$ data from seven samples of Globigerinoides ruber and nine samples of Globigerinoides sacculifer ranging from 3.30 to 3.02 Ma (Wara and Ravelo, 2006). Faunal modern analog, alkenone and $\mathrm{Mg} / \mathrm{Ca}$ SST estimates are in excellent agreement (Dowsett and Robinson, 2009). Planktic foraminifera are abundant with good preservation. Application of the modern analog technique (Dowsett, 2007) showed high similarity ( $S C D$ values $\leq 0.18$ ) of Pliocene planktic foraminifer assemblages to modern Pacific assemblages.

\section{ODP Site 1239 (0.67 S., $82.08^{\circ}$ W., 1,413-meter water depth)}

This site was not included in the Dowsett and others (2012) verification dataset. The mean annual SST at this site along the Peru margin was estimated to be $25.6{ }^{\circ} \mathrm{C}$ with high confidence. The age model at this site was developed using biostratigraphy and an orbitally tuned oxygen isotope age model (Tiedemann and others, 2007). Temperature estimation was based on the modern analog technique using planktic foraminifera with a squared chord distance cutoff of 0.32 from 33 Hole 1239B samples between 3.27 and $2.96 \mathrm{Ma}$. Specimens were abundant and well preserved.

\section{Yabuta $\left(37.00^{\circ}\right.$ N., $137.00^{\circ}$ E., 0.0 -meter water depth)}

The mean annual SST at this Northwest Pacific site was estimated to be $17.4{ }^{\circ} \mathrm{C}$ with medium confidence (Dowsett and others, 2012). Molluskan and ostracod assemblages from the Yabuta Formation (3.4 to 2.3 Ma) were analyzed for SST estimation. The age of the Yabuta Formation was constrained by diatom and planktic foraminiferal biostratigraphy. Quantitative estimates of paleotemperatures were obtained using the modem analog technique on 52 ostracod and 55 mollusk samples (Cronin and others, 1994). Ostracod and mollusk specimens were abundant and well preserved. SCD values indicated general similarities but exceeded 0.5 .

\section{Sasaoka $\left(39.50^{\circ}\right.$ N., $140.50^{\circ}$ E., 0.0 -meter water depth)}

The mean annual SST at this Northwest Pacific site was estimated to be $16.3{ }^{\circ} \mathrm{C}$ with medium confidence (Dowsett and others, 2012). The modern analog technique was employed to quantitatively and objectively compare fossil and modern ostracod assemblages and to estimate paleotemperature and paleodepth from three samples from the lower Sasaoka Formation (Ikeya and Cronin, 1993). The late Pliocene age of these samples was determined by calcareous microfossil biostratigraphy. Ostracod specimens were abundant and well preserved. SCD values indicated general similarities but exceeded 0.3.

\section{Rangitikei River ( $39.50^{\circ}$ S., $175.87^{\circ}$ E., 0.0-meter water depth)}

The mean annual SST at this New Zealand site was estimated to be $17.6^{\circ} \mathrm{C}$ with medium confidence (Dowsett and others, 2012). Planktic foraminifera were common to abundant and well preserved in 76 samples collected from 0 to 1538.5 meters (m) above the base section (Foley and others, 2015). Age control was provided by an integrated chronology based on radiometric ages, interbedded rhyolitic tephra, biostratigraphic data, paleomagnetic polarity measurements, and cycle correlations with the oxygen isotope timescale, establishing an astronomical chronostratigraphy (Naish and others, 1998) and an age range for these samples of 3.35 to 2.25 Ma. SST estimates based upon the modern analog technique (Dowsett and Robinson, 1998) first appeared in Dowsett and others (1999).

\section{East Kamchatka $\left(56.00^{\circ}\right.$ N., $163.00^{\circ}$ E., $0.0-$ meter water depth)}

The mean annual SST at this this Karaginsky Island site in eastern Kamchatka was estimated to be $7.5^{\circ} \mathrm{C}$ with medium confidence (Dowsett and others, 2012). Ages of outcrop beds and members were determined from a relatively complete biostratigraphic sequence from assemblages of mollusks, diatoms, benthic foraminifera, ostracods, spores and pollen, paleomagnetics, and fission track dating of volcanic ash of Karaginsky Island Pliocene deposits (Gladenkov and others, 1991). A total of 95 molluskan, 75 benthic foraminiferal, and about 35 ostracod species were identified from the Karaginsky section. An unknown number of samples $(\geq 20)$ from the east Kamchatka site, dated at 3.48 to $2.85 \mathrm{Ma}$, were assessed qualitatively for SST estimation through comparison with the temperature ranges of extant taxa. 


\section{Karaginsky (58.85 N., $164.04^{\circ}$ E., 0.0-meter water depth)}

The mean annual SST estimate at this Karaginsky Island site in eastern Kamchatka was estimated to be $8.2{ }^{\circ} \mathrm{C}$ with medium confidence (Dowsett and others, 2012). Ages of outcrop beds and members were determined from a relatively complete biostratigraphic sequence from assemblages of mollusks, diatoms, benthic foraminifera, ostracods, spores and pollen, paleomagnetics, and fission track dating of volcanic ash of Karaginsky Island Pliocene deposits (Gladenkov and others, 1991). A total of 95 molluskan, 75 benthic foraminiferal, and about 35 ostracod species were identified from the Karaginsky section. A qualitative assessment of the benthic marine assemblages in an unknown number of Karaginsky samples ( $\geq 20)$ dated at 3.48 to $2.85 \mathrm{Ma}$ provided SST estimates through comparison with temperature ranges of extant taxa.

\section{Indian Ocean}

SST estimates for these Indian Ocean Sites presented in Dowsett and others (2012) were based on the factor analytic transfer function GSF36 (Robinson and others, 2018). We have since revised those SST estimates using the modern analog technique, and the mean annual SST estimates reported below are calculated by averaging the warm and cold season estimates. The descriptions below incorporate the revised estimates, estimation method and confidence assessment, and differ slightly from what is shown in Dowsett and others (2012). The revised confidence rating follows the established metric (table 1).

\section{ODP Site 709 (3.92 ${ }^{\circ}$ S., $60.55^{\circ}$ E., 3,039-meter water depth)}

The mean annual SST at this western equatorial Indian Ocean site was estimated to be $27.6^{\circ} \mathrm{C}$ with very high confidence (table 1). ODP Site 709 in the western equatorial Indian Ocean is located about 2,200 km east of mainland Africa and sits atop a topographic high. During the winter, the site is under the influence of the eastward flowing Equatorial Countercurrent, and during the summer, a small cyclonic gyre encircles Site 709, entrapping and recirculating northward flowing water along the African coast. Hole 709C mid-Piacenzian foraminifer and nannofossil oozes were dated through a combination of oxygen isotope stratigraphy and magnetobiochronology (Shipboard Scientific Party, 1988b; Rio and others, 1990; Shackleton and Hall, 1990) and span $1.7 \mathrm{~m}$ of core. The tuned age model of Karas and others (2011) was adopted here. Temperature estimation was based on the modern analog technique with $\mathrm{SCD}$ values $\leq 0.15$. Planktic foraminifer specimens were abundant and well preserved over 21 samples ranging from 3.31 to $2.83 \mathrm{Ma}$ (Robinson and others, 2018).

\section{ODP Site $716\left(4.93^{\circ}\right.$ N., $73.28^{\circ}$ E., 544-meter water depth)}

The mean annual SST at this western equatorial Indian Ocean site was estimated to be $27.2^{\circ} \mathrm{C}$ with high confidence (table 1). ODP Site 716 is located $580 \mathrm{~km}$ southwest of the southern tip of India at the southern limit of the Arabian Sea. It is situated in a shallow depression in the center of the Maldives Ridge. A single fossiliferous lithologic unit with high carbonate content preserves continuous late Miocene through Pleistocene sediment accumulation (Shipboard Scientific Party, 1988c). Mid-Piacenzian sediments of Hole 716B were identified using magnetobiochronology of (Rio and others, 1990) and span $12 \mathrm{~m}$ of core. Temperature estimation was based on the modern analog technique with SCD values $\leq 0.27$. Planktic foraminifer specimens were abundant and moderately well preserved over 23 samples ranging from 3.33 to $2.95 \mathrm{Ma}$ (Robinson and others, 2018).

\section{ODP Site 722 ( $16.62^{\circ}$ N., $59.80^{\circ}$ E., 2,022-meter water depth)}

ODP Site 722 is located in the Arabian Sea, off the coast of Saudi Arabia, in an area of seasonal monsoonal upwelling. The mean annual SST at this Arabian Sea site was estimated to be $25.7{ }^{\circ} \mathrm{C}$ with high confidence (table 1). Miocene to Holocene sediments with abundant calcareous microfossils characterize the top $221.5 \mathrm{~m}$ of core (Shipboard Scientific Party, 1989a). Mid-Piacenzian Hole 722A sediments were identified by magnetobiochronology (Spaulding and others, 1991) and span $12 \mathrm{~m}$ of core. The age model of Herbert and others (2010) was adopted here. New temperature estimates were based on the modern analog technique with $\mathrm{SCD}$ values $\leq 0.28$. Planktic foraminifer specimens were abundant and moderately well preserved over 11 samples ranging from 3.23 to $2.79 \mathrm{Ma}$ (Robinson and others, 2018). 


\section{ODP Site 754 (30.93 S., $93.57^{\circ}$ E., 1,064-meter water depth)}

Site 754 is located in the central Indian Ocean, $2,100 \mathrm{~km}$ west-southwest of Perth, Western Australia, inside the southern subtropical gyre. The mean annual SST at this site was estimated to be $25.7^{\circ} \mathrm{C}$ with high confidence (table 1). The mid-Piacenzian interval of Hole 754A was identified using magnetobiochronology (Shipboard Scientific Party, 1989b) and spans $1.8 \mathrm{~m}$ of core. New temperature estimates were based on the modern analog technique with SCD values ranging from 0.27 to 0.53 . Planktic foraminifer specimens were abundant and well preserved over 30 samples ranging from 3.35 to $2.71 \mathrm{Ma}$ (Robinson and others, 2018).

\section{ODP Site 757 (17.02 S., 88.18 E., 1,652-meter water depth)}

This site was not included in the Dowsett and others (2012) verification dataset. ODP Site 757 is located on the Ninetyeast Ridge, in the central Indian Ocean. This location is south of the equatorial convergence zone on the northern edge of the subtropical gyre, just south of the main path of Indonesian Throughflow. The mean annual SST at this central Indian Ocean site was estimated to be $26.6^{\circ} \mathrm{C}$ with high confidence (table 1). The mid-Piacenzian interval of Hole 757B was identified using magnetobiochronology (Shipboard Scientific Party, 1989c) and spans $2.3 \mathrm{~m}$ of core. Temperature estimation was based on the modern analog technique with $S C D$ values $\leq 0.17$. Planktic foraminifer specimens were abundant and moderately well preserved over 12 samples between 3.35 and $2.91 \mathrm{Ma}$ (Robinson and others, 2018).

\section{ODP Site 758 (5.38 N., $90.37^{\circ}$ E., 2,924-meter water depth)}

ODP Site 758 is located on the northern end of the Ninetyeast Ridge at the mouth of the Bay of Bengal, between Sri Lanka and the Indonesian islands. Today, this site is influenced by the alternating summer and winter monsoon currents. The mean annual SST at this site was estimated to be $27.2^{\circ} \mathrm{C}$ with high confidence (table 1). Mid-Piacenzian sediments of Hole $758 \mathrm{~A}$ were identified through a combination of oxygen isotope stratigraphy, magnetostratigraphy (Farrell and Janecek, 1991), and magnetobiochronology (Shipboard Scientific Party, 1989d) and span $4.2 \mathrm{~m}$ of core. The age model for Site 758 was developed by converting the chronology of Farrell and others (1995) to the timescale of Berggren and others (1995). New temperature estimates were based on the modern analog technique with SCD values ranging from 0.18 to 0.55 (with an average of 0.36 ). Specimens were abundant and well preserved over 30 samples spanning 3.38 to $2.92 \mathrm{Ma}$ (Robinson and others, 2018).

\section{ODP Site $763\left(20.59^{\circ}\right.$ S., $112.21^{\circ}$ E., 1,368-meter water depth)}

ODP Site 763 is located off the western coast of Australia, on the western part of the central Exmouth Plateau, and is directly influenced by the Leeuwin Current. The Leeuwin Current transports relatively warm and less saline tropical waters from the Indonesian Throughflow region southward along the Australian coast, suppressing coastal upwelling typically found along western continental margins. The mean annual SST at this eastern tropical Indian Ocean site was estimated to be $27.2^{\circ} \mathrm{C}$ with very high confidence (table 1). The mid-Piacenzian section of the core is abundant with calcareous microfossils (Shipboard Scientific Party, 1990a). Mid-Piacenzian sediments of ODP Hole 763A were identified through a combination of paleomagnetics (Tang, 1992) and magnetobiochronology (Shipboard Scientific Party, 1990a) and span $3.8 \mathrm{~m}$ of core. The orbitally tuned age model of Karas and others (2011) was adopted here. New temperature estimates were based on the modern analog technique with squared chord distance values $<0.13$. Specimens were abundant and well preserved over 29 samples from 3.22 to $2.94 \mathrm{Ma}$ (Robinson and others, 2018).

\section{Southern Ocean}

With the exception of Site PS1448, all SST estimates in the Southern Ocean were based on fossil diatom assemblages and their relationship to modern assemblages and temperatures near the Antarctic polar front. This SST estimation method only provides summer temperatures. As described in Dowsett, Robinson, Stoll, and others (2010), PRISM mean annual SST estimates are averages of the diatom-derived summer temperatures and the interpolated August SST value in the PRISM3 global 12-month SST reconstruction. 


\section{AND-1B (77.89 S., $167.09^{\circ}$ E., 917-meter water depth)}

ANDRILL site AND-1B is located beneath the McMurdo-Ross Ice Shelf in the Ross Sea, in a flexural moat surrounding Ross Island. The mean annual SST at this Southern Ocean site was estimated to be $-0.4{ }^{\circ} \mathrm{C}$ with high confidence (Dowsett and others, 2012). The age model for AND-1B was constructed using a combination of paleomagnetic reversals, 10 biostratigraphic events, and cyclostratigraphy (Naish and others, 2009). Semiquantitative temperature estimation was based on extant diatom assemblages in 30 samples, and was supported by inferences from more abundant extinct taxa; diatoms were abundant with good to excellent preservation (Riesselman and Dunbar, 2013). Summer (January to March) temperature estimates were averaged from two discrete diatom-bearing units with ages of 3.2 and 3.0 Ma, separated by glacial diamict and multiple erosional hiatuses.

\section{E13-17 (65.68 S., $124.11^{\circ}$ W., 4,724-meter water depth)}

The mean annual SST at this Southern Ocean site was estimated to be $3.0{ }^{\circ} \mathrm{C}$ with medium confidence (Dowsett and others, 2012). The age model for R/V Eltanin core E13-17 was constructed using a combination of incomplete paleomagnetics and seven biostratigraphic events (Barron, 1996a). Temperature estimation was based on extinct diatom assemblages and their relationship to modern assemblages and temperatures near the Antarctic polar front in 11 samples between 3.23 and $3.00 \mathrm{Ma}$. Diatoms in these samples exhibited poor preservation, and reworked diatoms were fairly common in the upper part of the core. Barron (1996a) considered these quantitative data to be of lesser quality than those from other cores in the same publication.

\section{E14-8 (59.67 S., $160.29^{\circ}$ W., 3,877-meter water depth)}

The mean annual SST at this Southern Ocean site was estimated to be $4.1^{\circ} \mathrm{C}$ with medium confidence (Dowsett and others, 2012). The age model for R/V Eltanin core E14-8 was constructed using a combination of incomplete paleomagnetics and six biostratigraphic events (Barron, 1996a). Temperature estimation was based on extinct diatom assemblages and their relationship to modern assemblages and temperatures near the Antarctic polar front in 11 samples between 3.12 and 2.92 Ma. Reworked diatoms were consistently numerous (averaging 18 percent). Barron considered these quantitative data to be of lesser quality than other cores in this publication.

\section{E36-33 (57.75 S., $150.88^{\circ}$ E., 3,952-meter water depth)}

The mean annual SST at this Southern Ocean site was estimated to be $4.0^{\circ} \mathrm{C}$ with medium confidence (Dowsett and others, 2012). The age model for R/V Eltanin core 36-33 was constructed using a complete paleomagnetic record and five biostratigraphic events (Barron, 1996a). Temperature estimation was based on extinct diatom assemblages and their relationship to modern assemblages and temperatures near the Antarctic polar front. Diatoms in eight samples between 3.12 and 2.95 Ma were abundant with good to excellent preservation.

\section{E50-28 (62.90 $90^{\circ}$., $150.68^{\circ}$ E., 3,489-meter water depth)}

R/V Eltanin core 50-28 was collected in the southwest Indian Ocean. The mean annual SST at this Southern Ocean site was estimated to be $2.1{ }^{\circ} \mathrm{C}$ with medium confidence (Dowsett and others, 2012). The age model for site E50-28 was constructed using a combination of paleomagnetic reversal data and three biostratigraphic events (Ciesielski and Weaver, 1973; Barron, 1996b). Temperature estimation was based on extinct diatom assemblages and their relationship to modern assemblages and temperatures near the Antarctic polar front. Diatoms in six samples between 3.20 and 2.95 Ma were abundant with good preservation.

\section{E50-33 (61.09 S., $170.06^{\circ}$ E., 4,550-meter water depth)}

The mean annual SST at this Southern Ocean site was estimated to be $3.7^{\circ} \mathrm{C}$ with medium confidence (Dowsett and others, 2012). The age model at R/V Eltanin core 50-33 was constructed using a complete paleomagnetic record and six biostratigraphic events (Barron, 1996a). Temperature estimation was based on extinct diatom assemblages and their relationship to modern assemblages and temperatures near the Antarctic polar front in 11 samples between 3.19 and 2.83 Ma. Diatoms in the lower part of the core exhibited poor preservation. 


\section{PS1448 (58.64 ${ }^{\circ}$., $7.92^{\circ}$ E., 4,970-meter water depth)}

The mean annual SST at this Southern Ocean site was estimated to be $1.9^{\circ} \mathrm{C}$ with medium confidence (Dowsett and others, 2012). Age control at R/V Polarstern site PS1448 was provided by an unpublished paleomagnetic record that identified all events within the Gauss normal (base of chron C2An.3n through top of C2An.1n), as presented in Westall and Fenner (1990). Paleotemperature was estimated from a reconstruction of Antarctic polar front position, based on the clay-biosiliceouscalcareous lithofacies succession across a three-site transect (Westall and Fenner, 1990; Barron, 1996b). Lithologic data from 21 samples within the Gauss normal (Westall and Fenner, 1990), combined with unpublished preliminary diatom observations, indicated that site PS1448 lay south of the polar frontal zone throughout the PRISM3 interval (Barron, 1996b). The mean annual SST estimate was derived from modern summer and winter SST at the appropriate distance from the Antarctic polar front (Dowsett and others, 1996).

\section{DSDP Site 266 ( $56.40^{\circ}$ S., $110.11^{\circ}$ E., 4,167-meter water depth)}

Site 266 is located on the south flank of the Southeast Indian Ridge. The mean annual SST at this Southern Ocean site was estimated to be $3.5^{\circ} \mathrm{C}$ with medium confidence (Dowsett and others, 2012). The age model for Site 266 was constructed using six biostratigraphic datums (Chen, 1975; Barron, 1996b). Temperature estimation was based on extinct diatom assemblages and their relationship to modern assemblages and temperatures near the Antarctic polar front. Diatoms in five samples between 3.2 and 2.8 Ma are abundant with good preservation (Barron, 1996b).

\section{DSDP Site 274 (68.99 S., $173.43^{\circ}$ E., 3,305-meter water depth)}

The mean annual SST at this Southern Ocean site was estimated to be $1.4{ }^{\circ} \mathrm{C}$ with medium confidence (Dowsett and others, 2012). The age model at Site 274 was constructed using four biostratigraphic events (Barron, 1996a). Temperature estimation was based on both extinct and extant diatom assemblages and their relationship to modern assemblages and temperatures near the Antarctic polar front. Diatoms in 11 samples between 3.17 and 2.96 Ma were abundant with good to excellent preservation (Barron, 1996a; Fleming and Barron, 1996).

\section{DSDP Site $323\left(63.68^{\circ}\right.$ S., $97.99^{\circ}$ W., 5,004-meter water depth)}

The mean annual SST at this Southern Ocean site was estimated to be $3.6^{\circ} \mathrm{C}$ with medium confidence (Dowsett and others, 2012). The age model at Site 323 was constructed using four biostratigraphic datums (Barron, 1996a). Temperature estimation was based on extinct diatom assemblages and their relationship to modern assemblages and temperatures near the Antarctic polar front. Diatoms in three samples between 3.06 and 3.00 Ma were abundant with good to excellent preservation.

\section{ODP Site 690 (65.16 S., $1.21^{\circ}$ E., 2,914-meter water depth)}

The mean annual SST at this Southern Ocean site was estimated to be $2.0^{\circ} \mathrm{C}$ with medium confidence (Dowsett and others, 2012). The age model at Site 690 was constructed using a combination of incomplete paleomagnetics and four biostratigraphic events (Barron, 1996a). The upper part of the core was characterized by a hiatus. Temperature estimation was based on extinct diatom assemblages and their relationship to modern assemblages and temperatures near the Antarctic polar front. Diatoms in nine samples between 3.19 and 3.09 Ma were abundant with good to excellent preservation.

\section{ODP Site 693 (70.83 S., $14.57^{\circ}$ W., 2,359-meter water depth)}

The mean annual SST at this Southern Ocean site was estimated to be $1.2{ }^{\circ} \mathrm{C}$ with medium confidence (Dowsett and others, 2012). The age model at Site 693 was developed through biostratigraphy alone using five events (Barron, 1996a). Temperature estimation was based on extinct diatom assemblages and their relationship to modern assemblages and temperatures near the Antarctic polar front. Diatoms were abundant in 13 samples between 3.20 and 2.82 Ma and exhibited poor preservation. 


\section{ODP Site 695 (62.39 S., $43.45^{\circ}$ W., 1,300-meter water depth)}

The mean annual SST at this Southern Ocean site was estimated to be $2.0^{\circ} \mathrm{C}$ with medium confidence (Dowsett and others, 2012). The age model at Site 695 was constructed using a complete paleomagnetic record combined with four biostratigraphic events (Barron, 1996a). Temperature estimation was based on both extinct and extant diatom assemblages and their relationship to modern assemblages and temperatures near the Antarctic polar front. Diatoms in 14 samples between 3.17 and 2.67 Ma were abundant with good to excellent preservation.

\section{ODP Site 699 (51.54ํ S., $30.68^{\circ}$ W., 3,706-meter water depth)}

Site 699 lies in the Georgia Basin near the Falkland Plateau. The mean annual SST at this Southern Ocean site was estimated to be $4.6^{\circ} \mathrm{C}$ with medium confidence (Dowsett and others, 2012). The age model at Site 699 was constructed using a combination of incomplete paleomagnetics and six biostratigraphic events (Hailwood and Clement, 1991; Barron, 1996b). Temperature estimation was based on extinct diatom assemblages and their relationship to modern assemblages and temperatures near the Antarctic polar front. Diatoms in 18 samples between 3.12 and $2.72 \mathrm{Ma}$ were abundant with good preservation (Barron, 1996b).

\section{ODP Site $736\left(49.40^{\circ}\right.$ S., $71.66^{\circ}$ E., 629 -meter water depth)}

The mean annual SST at this Southern Ocean site was estimated to be $5.8^{\circ} \mathrm{C}$ with medium confidence (Dowsett and others, 2012). The PRISM3 interval at Site 736 was identified using diatom biostratigraphy (Baldauf and Barron, 1991; Cody and others, 2008). Temperature estimation was based on extinct diatom assemblages and their relationship to modern assemblages and temperatures near the Antarctic polar front. Diatoms in 10 samples within the PRISM3 interval were abundant with good preservation (Baldauf and Barron, 1991).

\section{ODP Site $745\left(59.60^{\circ}\right.$ S., $85.86^{\circ}$ E., 4,083-meter water depth)}

The mean annual SST at this Southern Ocean site was estimated to be $2.5^{\circ} \mathrm{C}$ with medium confidence (Dowsett and others, 2012). The PRISM3 interval at Site 745 was identified using a combination of paleomagnetic reversals and diatom biostratigraphy (Baldauf and Barron, 1991; Cody and others, 2008). Temperature estimation was based on extinct diatom assemblages and their relationship to modern assemblages and temperatures near the Antarctic polar front. Diatoms in 16 samples within the PRISM3 interval were common with good preservation (Baldauf and Barron, 1991).

\section{ODP Site 747 ( $54.81^{\circ}$ S., $76.79^{\circ}$ E., 1,696-meter water depth)}

Site 747 is located in the Indian Ocean sector of the Southern Ocean on the middle part of the Kerguelen Plateau, about $500 \mathrm{~km}$ south of the Antarctic polar front. This high-latitude location is south of the modern Antarctic Convergence and in the main flow of the modern Antarctic Circumpolar Current. The mean annual SST at this Southern Ocean site was estimated to be $3.2^{\circ} \mathrm{C}$ with medium confidence (Dowsett and others, 2012). The age model for this site was constructed using integrated magnetobiostratigraphy (Harwood and others, 1992). Temperature estimation was based on extinct diatom assemblages and their relationship to modern assemblages and temperatures near the Antarctic polar front. Diatoms in 12 Hole 747A samples between 3.12 and 2.72 Ma were abundant with good preservation (Harwood and Maruyama, 1992; Barron, 1996b). Although conditions in the Southern Ocean generally do not favor carbonate-producing organisms, sediment accumulation and carbonate preservation are enhanced on the shallow plateau, allowing for foraminiferal studies. Planktic foraminifera were abundant, well preserved, and dominated by Neogloboquadrina pachyderma (sinistral) throughout the mid-Piacenzian in 34 samples ranging from 3.38 to $2.73 \mathrm{Ma}$ (Foley and others, 2015).

\section{ODP Site 748 ( $58.44^{\circ}$ S., $78.98^{\circ}$ E., 1,290-meter water depth)}

The mean annual SST at this Southern Ocean site was estimated to be $2.4{ }^{\circ} \mathrm{C}$ with medium confidence (Dowsett and others, 2012). The PRISM3 interval at Site 748 was identified using a combination of paleomagnetic reversals and diatom biostratigraphy (Harwood and others, 1992; Cody and others, 2008). Temperature estimation was based on extinct diatom assemblages and their relationship to modern assemblages and temperatures near the Antarctic polar front. Diatoms in seven samples within the PRISM3 interval were abundant with excellent preservation (Harwood and Maruyama, 1992). 


\section{ODP Site 751 (57.73ㅇ․, $79.81^{\circ}$ E., 1,634-meter water depth)}

Site 751 is located on the southern part of the Kerguelen Plateau. The mean annual SST at this Southern Ocean site was estimated to be $2.7^{\circ} \mathrm{C}$ with medium confidence (Dowsett and others, 2012). The age model for this site was constructed using integrated magnetobiostratigraphy (Harwood and others, 1992; Barron, 1996b). Temperature estimation was based on extinct diatom assemblages and their relationship to modern assemblages and temperatures near the Antarctic polar front. Diatoms from six samples between 3.08 and 2.86 Ma were abundant with excellent preservation (Barron, 1996b). Planktic foraminifera were abundant, well preserved, and dominated by Neogloboquadrina pachyderma (sinistral) throughout the mid-Piacenzian in 26 samples ranging from 3.29 to $2.95 \mathrm{Ma}$ (Foley and others, 2015).

\section{Northern High Latitudes}

Estimates of SST for ODP Sites 907 and 909 reflect summer temperatures. As described in Dowsett, Robinson, Stoll, and others (2010), mean annual SST estimates are averages of these summer temperature estimates and the interpolated February SST value in the PRISM3 global 12-month SST reconstruction.

\section{ODP Site 907 (69.25 N., $12.70^{\circ}$ W., 1,801-meter water depth)}

Site 907 is located in the southwestern part of the Norwegian-Greenland Sea on the Iceland Plateau. The mean annual SST at this site was estimated to be $11.7^{\circ} \mathrm{C}$ with high confidence (Dowsett and others, 2012). A nearly complete magnetic stratigraphy exists throughout the Gauss geomagnetic polarity chron at Hole 907A (Channell and others, 1999), and an age model based on Argon isotope $\left({ }^{40} \mathrm{Ar} /{ }^{39} \mathrm{Ar}\right.$ ) ages (Lacasse and van den Bogaard, 2002) yielded a sedimentation rate of $6.1 \mathrm{~cm} / \mathrm{k} . \mathrm{y}$. The summer SST estimate was the mean of three Mg/Ca samples between 3.3 and 3.0 Ma (Robinson, 2009). Neogloboquadrina pachyderma (sinistral) was used in $\mathrm{Mg} / \mathrm{Ca}$ estimates; in the three samples analyzed, the specimens were abundant and exhibited good preservation (Robinson, 2009). Most samples were barren of foraminifera, and none produced an alkenone estimate.

\section{ODP Site 909 ( $78.58^{\circ}$ N., $3.07^{\circ}$ E., 2,519-meter water depth)}

Site 909 is located in the Fram Strait between the Norwegian-Greenland Sea and the Arctic Ocean. The mean annual SST at this site was estimated to be $10.2{ }^{\circ} \mathrm{C}$ with medium confidence (Dowsett and others, 2012). At Hole 909C, an age model based on magnetozone boundaries (Myhre and others, 1995) yielded a sedimentation rate of 6.4 to $6.8 \mathrm{~cm} / \mathrm{k} . \mathrm{y}$. The reported summer SST estimate was from a single $\mathrm{Mg} / \mathrm{Ca}$ sample at 3.3 Ma (Robinson, 2009); most samples ranging from 3.3 to $3.0 \mathrm{Ma}$ (47 of 48 ) were barren, and few (9 of 48) produced an alkenone estimate with an unacceptable average total abundance of $\mathrm{U}^{\mathrm{k}^{\prime}}<0.3 \mu \mathrm{g} / \mathrm{g}$. Neogloboquadrina pachyderma (sinistral) was used to estimate $\mathrm{Mg} / \mathrm{Ca}$; in the sample analyzed, the specimens were common and exhibited good preservation (Robinson, 2009).

\section{North Sea $\left(52.16^{\circ}\right.$ N.,1.53 ${ }^{\circ}$ E., 0.0 -meter water depth)}

The Coralline Crag Formation is exposed along the North Sea shore at Suffolk, England. This updated North Sea site replaces the original North Sea site with SST estimates based on ostracod assemblages (Wood and others, 1993) from samples that are now known to predate the PRISM3 interval (discussed in the next section). The new mean annual SST estimate at this site was $13.6{ }^{\circ} \mathrm{C}$ with medium confidence and was based on mollusks (Dowsett and others, 2012). Age determination for these Coralline Crag Formation samples was determined from calcareous nannofossils, planktic foraminifera, and dinoflagellates, suggesting that the youngest Coralline Crag deposits extend into the Mammoth subchron (Williams and others, 2009). Estimates of SST from this youngest section were derived from 52 oxygen isotopic measurements of 2 well preserved mollusks (Johnson and others, 2009; Williams and others, 2009).

\section{Colvillian $\left(70.29^{\circ}\right.$ N., $150.42^{\circ}$ W., $0.0-$ meter water depth)}

The mean annual SST estimate at this site in the northern Alaska Arctic coastal plain was estimated to be $1.2{ }^{\circ} \mathrm{C}$ with high confidence (Dowsett and others, 2012). The Colvillian Formation age of 3.2 to $2.5 \mathrm{Ma}$ was determined from paleomagnetic and biostratigraphic data. (Brigham-Grette and Carter, 1992). Paleotemperature estimates were based on modern ecological limits of ostracod species and genera from 23 samples and, because most exposures represent interglacial deposits, represented interglacial conditions (Cronin and others, 1993). Ostracod data were presented in Brouwers (1994). Ostracods were abundant with good preservation. 


\section{Meighen Island $\left(79.00^{\circ}\right.$ N., $99.00^{\circ}$ W., $0.0-$ meter water depth)}

The mean annual SST estimate at Meighen Island in the Canadian Arctic was estimated to be $1.7^{\circ} \mathrm{C}$ with medium confidence (Dowsett and others, 2012). Beaufort Formation ages were determined from paleomagnetic and (or) biostratigraphic data, dated to 3.9 to $3.1 \mathrm{Ma}$ to within approximately 200 to $500 \mathrm{k}$.y. (Brigham-Grette and Carter, 1992). Paleotemperature estimates were based on modern ecological limits of ostracod species and from three samples representing interglacial conditions (Cronin and others, 1993). Ostracods were common and generally well preserved.

\section{Sites Removed From the PRISM Sea Surface Temperature Dataset}

Over the last 30 years, the PRISM interval has been revised toward a more refined and well-defined period. At the same time, continuous improvements in the development of age models have redefined the chronologies of existing sediment cores. Samples from the six sites listed below, once included in the PRISM SST dataset, do not fall inside the PRISM3 interval and have been removed.

\section{DSDP Site $183\left(54.58^{\circ}\right.$ N., $161.21^{\circ}$ W., 4,708-meter water depth)}

This site from the central North Pacific was initially included in the PRISM3 mean annual SST reconstruction (Dowsett, Robinson, Stoll, and others, 2010). Samples for which SST had been estimated using diatom-based paleoclimate equations (see Barron, 1995) were later found to be outside the PRISM3 interval after a reevaluation of the original age model.

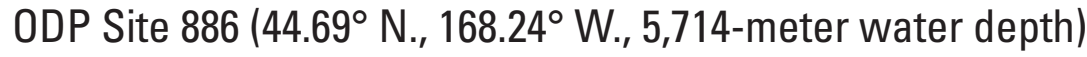

This site from the central North Pacific was initially included in the PRISM3 mean annual SST reconstruction (Dowsett, Robinson, Stoll, and others, 2010). The original chronology was based on paleomagnetic stratigraphy and radiolarian biochronology, and SST estimates were based on diatom paleoclimate ratios (see Barron, 1995). A reevaluation of the age model placed these samples outside the PRISM3 interval.

\section{ODP Site 646 (58.25 N., $48.33^{\circ}$ W., 3,440-meter water depth)}

Site 646 is located in the southeastern part of the Labrador Sea, southwest of Greenland and west of the Eirik Ridge. This site was initially included in the PRISM3 mean annual SST reconstruction (Dowsett, Robinson, Stoll, and others, 2010). Our age model for this site was based on a combination of biostratigraphic and magnetostratigraphic datums (Baldauf and others, 1989), both of which were limited by the variable core recovery and high-latitude, low-diversity nature of the fossil assemblages. This chronology indicated that cores 27 through 29 represent the PRISM3 interval. No sediments were recovered in core 27, and only a few tens of centimeters of disturbed material were recovered in core 28. Sediments from core 29 yielded sparse numbers of planktic foraminifera with sample sizes generally too small to be analyzed with transfer function techniques (Dowsett and Poore, 1991). However, the few planktic foraminifera recovered were Neogloboquadrina atlantica, which along with the presence of ice rafted detritus suggest conditions similar to those today near the polar front (Dowsett and Poore, 1991). An improved age model indicates that our 72 samples from Hole 646B (Dowsett and others, 1988; PRISM Project Members, 1996) range from 5.13 to $3.36 \mathrm{Ma}$, placing these samples fully outside the PRISM3 interval.

\section{ODP Site 911 (80.47 N., 8.23 E., 902-meter water depth)}

Site 911 is located on the shallow southern part of the Yermak Plateau in the Arctic Ocean. Paleomagnetics of younger sediments (Myhre and others, 1995) and nannofossil datums (Sato and Kameo, 1996) were available to construct an age model for Hole 911A which yielded a sedimentation rate of $12.5 \mathrm{~cm} / \mathrm{k}$.y. and a mean annual SST estimate of $12.2{ }^{\circ} \mathrm{C}$ with medium confidence (Dowsett and others, 2012). This interpolation assumed a constant sedimentation rate through the study interval owing to lack of data indicating otherwise (Robinson, 2009), though more recent paleomagnetic research (Mattingsdal and others, 2014) indicates an age of 3.6 Ma for these samples, which places them fully outside the PRISM3 interval. The SST estimate was the mean of four alkenone samples in which the average total abundance of $\mathrm{U}^{\mathrm{k}^{\prime}}{ }_{37}$ in the samples was $0.33 \mu \mathrm{g} / \mathrm{g}$; most samples (43 of 47) did not produce an alkenone estimate (Robinson, 2009). 


\section{North Sea $\left(52.50^{\circ}\right.$ N., $1.50^{\circ}$ E., 0.0 -meter water depth)}

The Coralline Crag Formation is exposed along the North Sea shore at Suffolk, England. Age determination for the Coralline Crag Formation was determined from planktic algal cyst (3.6 to $3.4 \mathrm{Ma}$ ) and planktic foraminifer biostratigraphy (4.2 to 2.4 Ma; Wood and others, 1993). SST estimates were developed from a quantitative method of comparing ostracod assemblages to modern analogs (Wood and others, 1993) from 15 abundant and well preserved ostracod samples with dissimilarity values meeting the study-specific cutoff. It has since been determined, however, that these samples more likely predate the PRISM3 interval (Williams and others, 2009).

\section{Tjörnes $\left(66.16^{\circ}\right.$ N., $17.25^{\circ}$ W., 0.0 -meter water depth)}

On the northern coast of Iceland, along the Tjörnes Peninsula, a well exposed sequence of richly fossiliferous Pliocene and Pleistocene sediments intercalated with basalts provides a climate record between 1.0 and about 5.0 Ma. At Tjörnes, Iceland, paleotemperatures (mean annual SST of $9.5^{\circ} \mathrm{C}$ ) were estimated from three methods analyzing 45 ostracod samples: a factor analytic transfer function resulting in communalities of 0.21 to 0.74 , temperature range and abundance observations, and examination of peak abundances of warm water genera, all in relative agreement (Cronin, 1991a; Dowsett and Poore, 1991). The original age model was based on an incomplete record of paleomagnetic reversals, potassium-argon (K/Ar) dating, and mollusk and ostracod biostratigraphy (Einarsson and Albertsson, 1988; Eiríksson and others, 1990; Cronin, 1991a). The new age model places the PRISM3 interval inside lava flows and places the existing ostracod data before 4.1 Ma and after 2.9 Ma (Verhoeven and others, 2011).

\section{Summary and Conclusions}

The PRISM SST dataset is the keystone of mid-Piacenzian paleoclimate studies. Research using this dataset has led to a better understanding of Earth system dynamics in warmer-than-modern climates both past and future. This report chronicles the evolution of the PRISM interval, the details of the SST dataset, the assessment of confidence in the SST estimates, and the application of a measure of stratigraphic fidelity. It represents 30 years of research by many PRISM scientists and collaborators beginning in 1988 with Tom Cronin, Dick Poore, and John Barron. The value of the PRISM paleoenvironmental reconstruction is apparent in the multitude of publications in which PRISM data have been used and cited.

We present the final SST verification dataset for the PRISM3 interval. Measures of stratigraphic fidelity in the record and confidence in the SST estimate at each site contained in this dataset assist in paleoclimate interpretations and in making comparisons with model output more insightful. An extensive analysis of a paleoenvironmental estimate's fundamental quantifiable attributes, supported by a qualitative assessment of uncertainty related to the complexity of the record, provides the most honest and useful measure of confidence. We have discussed each PRISM SST record in terms of age control, sample resolution and quality, and type and performance of temperature proxy, detailing the intricacies of each record and temperature estimate. Ratings of stratigraphic fidelity and confidence enable users of these data to determine which data series are appropriate for individual research efforts and paleoclimate experiments.

\section{Acknowledgments}

The data described herein constitute over three decades of focused paleoenvironmental research conducted by many scientists and science support staff at the U.S. Geological Survey. We acknowledge their time and efforts and are grateful for their dedication to Pliocene climate research. This work is a product of the Pliocene Research, Interpretation and Synoptic Mapping project (PRISM) and the Pliocene Model Intercomparison Project 2 (PlioMIP2). PRISM is funded by the U.S. Geological Survey Land Change Science Research and Development Program. This research used samples and (or) data provided by the International Ocean Discovery Program (IODP). 


\section{References Cited}

Andersson, Carin, 1997, Transfer function vs. modern analog technique for estimating Pliocene sea-surface temperatures based on planktic foraminiferal data, western equatorial Pacific Ocean: Journal of Foraminiferal Research, v. 27, no. 2, p. $123-132$. [Also available at https://doi.org/10.2113/gsjfr.27.2.123.]

Backman, Jan, and Pestiaux, Pierre, 1986, Pliocene discoaster abundance variations, Deep Sea Drilling Project site 606-Biochronology and paleoenvironmental implications, chap. 26 of Volume XCIV, Part 1 covering Leg 94 of the cruises of the drilling vessel Glomar Challenger, Norfolk, Virginia, to St. John's, Newfoundland, June-August 1983: Initial Reports of the Deep Sea Drilling Project, v. 94, p. 903-910. [Also available at https://doi.org/10.2973/dsdp.proc.94.126.1987.]

Baldauf, J.G., and Barron, J.A., 1991, Diatom biostratigraphy-Kerguelen Plateau and Prydz Bay regions of the Southern Ocean, chap. 29 of Barron, John, Anderson, John, Baldauf, J.G., and Larsen, Birger, eds., Kerguelen Plateau-Prydz Bay * * * sites 736-746* * *: Proceedings of the Ocean Drilling Program, Scientific Results, v. 119, p. 547-598. [Also available at https://doi.org/10.2973/odp.proc.sr.119.135.1991.]

Baldauf, J.G., Clement, Bradford, Aksu, A.E., de Vernal, Anne, Firth, John, Hall, Frank, Head, M.J., Jarrard, Richard, Kaminski, M.A., Lazarus, Dave, Monjanel, A.-L., Berggren, W.A., Gradstein, Felix, Knuttel, Stephen, Mudie, Peta, and Russell, M.D., Jr., 1989, Magnetostratigraphic and biostratigraphic synthesis of Ocean Drilling Program Leg 105-Labrador Sea and Baffin Bay, chap. 50 of Baffin Bay and Labrador Sea $* * *$ sites 645-647***: Proceedings of the Ocean Drilling Program, Scientific Results, v. 105, p. 935-956. [Also available at https://doi.org/10.2973/odp.proc.sr.105.165.1989.]

Baldauf, J.G., Thomas, E., Clement, B., Takayama, T., Weaver, P.P.E., Backman, J., Jenkins, G., Mudie, P.J., and WestbergSmith, M.J., 1986, Magnetostratigraphic and biostratigraphic synthesis, Deep Sea Drilling Project Leg 94, chap. 46 of Volume XCIV, Part 1 covering Leg 94 of the cruises of the drilling vessel Glomar Challenger, Norfolk, Virginia, to St. John's, Newfoundland, June-August 1983: Initial Reports of the Deep Sea Drilling Project, v. 94, p. 1159-1205. [Also available at https://doi.org/10.2973/dsdp.proc.94.146.1987.]

Ballantyne, A.P., Greenwood, D.R., Sinninghe Damsté, J.S., Csank, A.Z., Eberle, J.J., and Rybczynski, N., 2010, Significantly warmer Arctic surface temperatures during the Pliocene indicated by multiple independent proxies: Geology, v. 38, no. 7 , p. 603-606. [Also available at https://doi.org/10.1130/G30815.1.]

Barron, J.A., 1992, Pliocene paleoclimatic interpretation of DSDP site 580 (NW Pacific) using diatoms: Marine Micropaleontology, v. 20, no. 1, p. 23-44. [Also available at https://doi.org/10.1016/0377-8398(92)90007-7.]

Barron, J.A., 1995, High-resolution diatom paleoclimatology of the middle part of the Pliocene of the northwest Pacific, chap. 3 of Rea, D.K., Basov, I.A., Scholl, D.W., and Allan, J.F., eds., North Pacific transect * * * sites 881-887 * * *: Proceedings of the Ocean Drilling Program, Scientific Results, v. 145, p. 43-53. [Also available at https://doi.org/10.2973/ odp.proc.sr.145.102.1995.]

Barron, J.A., 1996a, Diatom constraints on sea surface temperatures and sea ice distribution during the middle part of the Pliocene: U.S. Geological Survey Open-File Report 96-713, 45 p. [Also available at https://doi.org/10.3133/ofr96713.]

Barron, J.A., 1996b, Diatom constraints on the position of the Antarctic Polar Front in the middle part of the Pliocene: Marine Micropaleontology, v. 27, nos. 1-4, p. 195-213. [Also available at https://doi.org/10.1016/0377-8398(95)00060-7.]

Barron, J.A., and Gladenkov, A.Y., 1995, Early Miocene to Pleistocene diatom stratigraphy of Leg 145, chap. 1 of Rea, D.K., Basov, I.A., Scholl, D.W., and Allan, J.F., eds., North Pacific transect * * * sites 881-887***: Proceedings of the Ocean Drilling Program, Scientific Results, v. 145, p. 3-19. [Also available at https://doi.org/10.2973/odp.proc.sr.145.101.1995.]

Bartoli, G., Sarnthein, M., Weinelt, M., Erlenkeuser, H., Garbe-Schönberg, D., and Lea, D.W., 2005, Final closure of Panama and the onset of Northern Hemisphere glaciation: Earth and Planetary Science Letters, v. 237, nos. 1-2, p. 33-44. [Also available at https://doi.org/10.1016/j.epsl.2005.06.020.]

Berger, W.H., Bickert, T., Schmidt, H., and Wefer, G., 1993, Quaternary oxygen isotope record of pelagic foraminifersSite 806, Ontong Java Plateau, chap. 22 of Berger, W.H., Kroenke, L.W., Janecek, T.R., and Sliter, W.V., eds., Ontong Java Plateau * * * sites 803-807***: Proceedings of the Ocean Drilling Program, Scientific Results, v. 130, p. 381-395. [Also available at https://doi.org/10.2973/odp.proc.sr.130.023.1993.] 
Berggren, W.A., 1972, Cenozoic biostratigraphy and paleobiogeography of the North Atlantic, chap. 14 of Volume XII covering Leg 12 of the cruises of the drilling vessel Glomar Challenger, Boston, Massachusetts, to Lisbon, Portugal, June-August 1970: Initial Reports of the Deep Sea Drilling Project, v. 12, p. 965-1001. [Also available at http://doi.org/10.2973/dsdp.proc.12.114.1972.]

Berggren, W.A., Kent, D.V., Swisher, C.C., III, and Aubry, M.-P., 1995, A revised Cenozoic geochronology and chronostratigraphy, in Berggren, W.A., Kent, D.V., Aubry, M.-P., and Hardenbol, Jan, eds., Geochronology, time scales and global stratigraphic correlation: SEPM Special Publication, v. 54, p. 129-212. [Also available at http://rci.rutgers.edu/ dvk/dvk_ REPRINTS/Berggren+1995.pdf.]

Berggren, W.A., Kent, D.V., and van Couvering, J.A., 1985, The Neogene-Part 2, Neogene geochronology and chronostratigraphy, in Snelling, N.J., ed., The chronology of the geological record: Geological Society of London Memoir, v. 10, p. 211-260. [Published by Blackwell Scientific Publications.] [Also available at https://doi.org/10.1144/GSL. MEM.1985.010.01.18.]

Bleil, Ulrich, 1985, The magnetostratigraphy of northwest Pacific sediments, Deep Sea Drilling Project Leg 86, chap. 17 of Volume LXXXVI covering Leg 86 of the cruises of the drilling vessel Glomar Challenger, Honolulu, Hawaii, to Yokohama, Japan, May-June 1982: Initial Reports of the Deep Sea Drilling Project, v. 86, p. 441-458. [Also available at https://doi.org/10.2973/dsdp.proc.86.117.1985.]

Brigham-Grette, J., and Carter, L.D., 1992, Pliocene marine transgressions of northern Alaska - Circumarctic correlations and paleoclimatic interpretations: Arctic, v. 45, no. 1, p. 74-89. [Also available at http://doi.org/10.14430/arctic1375.]

Brouwers, E.M., 1994, Late Pliocene paleoecologic reconstructions based on ostracod assemblages from the Sagavanirktok and Gubik Formations, Alaskan North Slope: Arctic, v. 47, no. 1, p. 16-33. [Also available at https://doi.org/10.14430/arctic1268.]

Bukry, David, 1978, Neogene coccolith stratigraphy, Mid-Atlantic Ridge, Deep Sea Drilling Project Leg 45, chap. 9 of Volume XLV covering Leg 45 of the cruises of the drilling vessel Glomar Challenger, San Juan, Puerto Rico, to San Juan, Puerto Rico, November 1975-January 1976: Initial Reports of the Deep Sea Drilling Project, v. 45, p. 307-312. [Also available at https://doi.org/10.2973/dsdp.proc.45.109.1979.]

Caballero, Rocio, and Dowsett, Harry, 2008, Mid-Pliocene planktic foraminifer census data from Ocean Drilling Program Hole 1237C: U.S. Geological Survey Data Series 336, accessed March 20, 2008, at http://pubs.usgs.gov/ds/336.

Canninga, G., Zijderveld, J.D.A., and van Hinte, J.E., 1986, Late Cenozoic magnetostratigraphy of Deep Sea Drilling Project hole 603C, Leg 93, on the North American continental rise off Cape Hatteras, chap. 30 of Volume XCIII, Part 1 covering Leg 93 of the cruises of the drilling vessel Glomar Challenger, Norfolk, Virginia, to Norfolk, Virginia, May-June 1983: Initial Reports of the Deep Sea Drilling Project, v. 93, p. 839-848. [Also available at https://doi.org/10.2973/ dsdp.proc.93.130.1987.]

Carter, R.M., McCave, I.N., Richter, Carl, Carter, Lionel, Aita, Yoshiaki, Buret, Christophe, Di Stefano, Agata, Fenner, Juliane, Fothergill, Patrick, Gradstein, Felix, Hall, Ian, Handwerger, David, Harris, Sara, Hayward, Bruce, Hu, Shouyun, Leah, Joseph, Khim, B.K., Lee, Y.-D., Millwood, Lynn, Rinna, Joachim, Smith, Gerald, Suzuki, Atsushi, Weedon, Graham, Wei, K.-Y., Wilson, Gary, and Winkler, Amelie, 1999, Southwest Pacific Gateways * * * sites 1119-1125***: Proceedings of the Ocean Drilling Program, Initial Reports, v. 181. [Also available at https://doi.org/10.2973/odp.proc.ir.181.2000.]

Čepek, P., Johnson, D., Krasheninnikov, V., and Pflaumann, U., 1978, Synthesis of the Leg 41 biostratigraphy and paleontology, Deep Sea Drilling Project, chap. 49 of Volume XLI covering Leg 41 of the cruises of the drilling vessel Glomar Challenger, Abidjan, Ivory Coast, to Malaga, Spain, February-April 1975: Initial Reports of the Deep Sea Drilling Project, v. 41, p. 1181-1198. [Also available at https://doi.org/10.2973/dsdp.proc.41.149.1978.]

Chandler, Mark, Rind, David, and Thompson, Robert, 1994, Joint investigations of the middle Pliocene climate IIGISS GCM Northern Hemisphere results: Global and Planetary Change, v. 9, nos. 3-4, p. 197-219. [Also available at https://doi.org/10.1016/0921-8181(94)90016-7.]

Channell, J.E.T., Amigo, A.E., Fronval, T., Rack, F., and Lehman, B., 1999, Magnetic stratigraphy at sites 907 and 985 in the Norwegian-Greenland Sea and a revision of the site 907 composite section, chap. 9 of Raymo, M.E., Jansen, Eystein, Blum, Peter, and Herbert, Timothy, eds., North Atlantic-Arctic gateways II * * * sites 980-987***: Proceedings of the Ocean Drilling Program, Scientific Results, v. 162, p. 131-148. [Also available at https://doi.org/10.2973/odp.proc.sr.162.036.1999.] 
Chen, P.-H., 1975, Antarctic radiolaria, chap. 11 of Volume XXVIII covering Leg 28 of the cruises of the drilling vessel Glomar Challenger, Freemantle, Australia, to Christchurch, New Zealand, December 1972-February 1973: Initial Reports of the Deep Sea Drilling Project, v. 28, p. 437-513. [Also available at https://doi.org/10.2973/dsdp.proc.28.111.1975.]

Ciesielski, P.F., and Weaver, F.M., 1973, Southern Ocean Pliocene paleotemperature based on silicoflagellate from deep sea cores: Antarctic Journal of the United States, v. 8, no. 5, p. 295-297. [Also available at https://s3.amazonaws.com/Antarctica/ AJUS/AJUSvVIIIn5/AJUSvVIIIn5p295.pdf.]

Clement, B.M., and Robinson, Frank, 1986, The magnetostratigraphy of Leg 94 sediments, chap. 12 of Volume XCIV, Part 1 covering Leg 94 of the cruises of the drilling vessel Glomar Challenger, Norfolk, Virginia, to St. John's, Newfoundland, June-August 1983: Initial Reports of the Deep Sea Drilling Project, v. 94, p. 635-650. [Also available at https://doi.org/10.2973/dsdp.proc.94.112.1987.]

Cody, R.D., Levy, R.H., Harwood, D.M., and Sadler, P.M., 2008, Thinking outside the zone-High-resolution quantitative diatom biochronology for the Antarctic Neogene: Palaeogeography, Palaeoclimatology, Palaeoecology, v. 260, nos. 1-2, p. 92-121. [Also available at https://doi.org/10.1016/j.palaeo.2007.08.020.]

Cotton, M.A., and Dowsett, H.J., 1990, Neogene planktic foraminiferal biostratigraphy from the Pacific and Caribbean sides of the lower Central American Isthmus [abs.]: Geological Society of America Annual Meeting, Abstracts with Programs, v. 22, no. 7 , p. A200.

Cronin, T.M., 1991a, Late Neogene marine ostracoda from Tjörnes, Iceland: Journal of Paleontology, v. 65, no. 5, p. 767-794. [Also available at http://www.jstor.org/stable/1305806.]

Cronin, T.M., 1991b, Pliocene shallow water paleoceanography of the North Atlantic Ocean based on marine ostracods: Quaternary Science Reviews, v. 10, nos. 2-3, p. 175-188. [Also available at https://doi.org/10.1016/0277-3791(91)90017-O.]

Cronin, T.M., and Dowsett, H.J., 1990, A quantitative micropaleontologic method for shallow marine paleoclimatologyApplication to Pliocene deposits of the western North Atlantic Ocean: Marine Micropaleontology, v. 16, nos. 1-2, p. 117-148. [Also available at https://doi.org/10.1016/0377-8398(90)90032-H.]

Cronin, T.M., Kitamura, Akihisa, Ikeya, Noriyuki, Watanabe, Mahito, and Kamiya, Takahiro, 1994, Late Pliocene climate change 3.4-2.3 Ma-Paleoceanographic record from the Yabuta Formation, Sea of Japan: Palaeogeography, Palaeoclimatology, Palaeoecology, v. 108, nos. 3-4, p. 437-455. [Also available at https://doi.org/10.1016/0031-0182(94)90245-3.]

Cronin, T.M., Whatley, Robin, Wood, Adrian, Tsukagoshi, Akira, Ikeya, Noriyuki, Brouwers, E.M., and Briggs, W.M., Jr., 1993, Microfaunal evidence for elevated mid-Pliocene temperatures in the Arctic Ocean: Paleoceanography, v. 8, no. 2, p. 161-173. [Also available at https://doi.org/10.1029/93PA00060.]

Curry, W.B., and Miller, K.G., 1989, Oxygen and carbon isotopic variation in Pliocene benthic foraminifers of the equatorial Atlantic, chap. 11 of Baldauf, Jack, Heath, G.R., Ruddiman, W.F., and Sarnthein, Michael, eds., Eastern tropical Atlantic $* * *$ sites 657-668 * * *: Proceedings of the Ocean Drilling Program, Scientific Results, v. 108, p. 157-166. [Also available at https://doi.org/10.2973/odp.proc.sr.108.134.1989.]

De Schepper, Stijn, Groeneveld, Jeroen, Naafs, B.D.A., Van Renterghem, Cédéric, Hennissen, Jan, Head, M.J., Louwye, Stephen, and Fabian, Karl, 2013, Northern Hemisphere glaciation during the globally warm early late Pliocene: PLoS One, v. 8, no. 12, article e81508, 15 p. [Also available at https://doi.org/10.1371/journal.pone.0081508.]

Dekens, P.S., Ravelo, A.C., and McCarthy, M.D., 2007, Warm upwelling regions in the Pliocene warm period: Paleoceanography, v. 22, no. 3, article PA3211, 12 p. [Also available at https://doi.org/10.1029/2006PA001394.]

Dowsett, Harry, 2007, Faunal re-evaluation of Mid-Pliocene conditions in the western equatorial Pacific: Micropaleontology, v. 53, no. 6, p. 447-456. [Also available at https://doi.org/10.2113/gsmicropal.53.6.447.]

Dowsett, Harry, Barron, John, and Poore, Richard, 1996, Middle Pliocene sea surface temperatures-A global reconstruction: Marine Micropaleontology, v. 27, nos. 1-4, p. 13-25. [Also available at https://doi.org/10.1016/0377-8398(95)00050-X.]

Dowsett, Harry, and Caballero, Rocío, 2007, Mid-Pliocene planktic foraminifer census data from Ocean Drilling Program hole 847C: U.S. Geological Survey Data Series 295, accessed September 14, 2007, at https://pubs.usgs.gov/ds/295. 
Dowsett, Harry, Robinson, Marci, Dwyer, Gary, Chandler, Mark, and Cronin, Thomas, 2006, PRISM 3 DOT1 Atlantic Basin reconstruction: U.S. Geological Survey Data Series 189, accessed November 28, 2016, at https:/pubs.usgs.gov/ds/2006/189/.

Dowsett, Harry, Robinson, Marci, and Foley, Kevin, 2015, A global planktic foraminifer census dataset for the Pliocene ocean: Scientific Data, v. 2, article 150076, 6 p. [Also available at https://doi.org/10.1038/sdata.2015.76.]

Dowsett, Harry, Robinson, Marci, Haywood, Alan, Salzmann, Ulrich, Hill, Daniel, Sohl, Linda, Chandler, Mark, Williams, Mark, Foley, Kevin, and Stoll, Danielle, 2010, The PRISM3D paleoenvironmental reconstruction: Stratigraphy, v. 7, nos. 2-3, p. 123-140. [Also available at http://www.micropress.org/microaccess/stratigraphy/issue-268/article-1692.]

Dowsett, Harry, Thompson, Robert, Barron, John, Cronin, Thomas, Fleming, Farley, Ishman, Scott, Poore, Richard, Willard, Debra, and Holtz, Thomas, Jr., 1994, Joint investigations of the middle Pliocene climate I-PRISM paleoenvironmental reconstructions: Global and Planetary Change, v. 9, nos. 3-4, p. 169-195. [Also available at https://doi.org/10.1016/ 0921-8181(94)90015-9.]

Dowsett, Harry, and West, Stephanie, 1993, Pliocene planktic foraminifer census data from Deep Sea Drilling Project hole 445: U.S. Geological Survey Open-File Report 93-307, 5 p. [Also available at https://doi.org/10.3133/ofr93307.]

Dowsett, Harry, and Willard, Debra, 1996, Southeast Atlantic marine and terrestrial response to middle Pliocene climate change: Marine Micropaleontology, v. 27, nos. 1-4, p. 181-193. [Also available at https://doi.org/10.1016/0377-8398(95)00059-3.]

Dowsett, H.J., 1988, Diachrony of late Neogene microfossils in the southwest Pacific Ocean-Application of the graphic correlation method: Paleoceanography, v. 3, no. 2, p. 209-222. [Also available at http://doi.org/10.1029/PA003i002p00209.]

Dowsett, H.J., 1989a, Application of the graphic correlation method to Pliocene marine sequences: Marine Micropaleontology, v. 14, nos. 1-3, p. 3-32. [Also available at https://doi.org/10.1016/0377-8398(89)90030-3.]

Dowsett, H.J., 1989b, Improved dating of the Pliocene of the eastern South Atlantic using graphic correlation—Implications for paleobiogeography and paleoceanography: Micropaleontology, v. 35, no. 3, p. 279-292. [Also available at https://doi.org/10.2307/1485684.]

Dowsett, H.J., 1991, The development of a long-range foraminifer transfer function and application to late Pleistocene North Atlantic climatic extremes: Paleoceanography, v. 6, no. 2, p. 259-273. [Also available at https://doi.org/10.1029/90PA02541.]

Dowsett, H.J., 1996, Mid-Pliocene planktonic foraminiferal assemblages from ODP site 704-Palaeoceanographical implications, in Moguilevsky, Alicia, and Whatley, Robin, eds., Microfossils and oceanic environments: University of Wales, Aberystwyth-Press, p. 177-186.

Dowsett, H.J., Barron, J.A., Poore, R.Z., Thompson, R.S., Cronin, T.M., Ishman, S.E., and Willard, D.A., 1999, Middle Pliocene paleoenvironmental reconstruction-PRISM2: U.S. Geological Survey Open-File Report 99-535, 33 p. [Also available at https://pubs.usgs.gov/of/1999/of99-535.]

Dowsett, H.J., and Cronin, T.M., 1990, High eustatic sea level during the middle Pliocene-Evidence from the southeastern U.S. Atlantic Coastal Plain: Geology, v. 18, no. 5, p. 435-438. [Also available at https://doi.org/10.1130/00917613(1990)018<0435:HESLDT>2.3.CO;2.]

Dowsett, H.J., Cronin, T.M., Poore, R.Z., Thompson, R.S., Whatley, R.C., and Wood, A.M., 1992, Micropaleontological evidence for increased meridional heat transport in the North Atlantic Ocean during the Pliocene: Science, v. 258, no. 5085, p. 1133-1135. [Also available at https://doi.org/10.1126/science.258.5085.1133.]

Dowsett, H.J., Foley, K.M., Robinson, M.M., and Herbert, T.D., 2017, PRISM late Pliocene (Piacenzian) alkenone - derived SST data: U.S. Geological Survey data release, accessed June 9, 2017, at https://doi.org/10.5066/F7959G1S.

Dowsett, H.J., Foley, K.M., Stoll, D.K., Chandler, M.A., Sohl, L.E., Bentsen, Mats, Otto-Bliesner, B.L., Bragg, F.J., Chan, W.-L., Contoux, Camille, Dolan, A.M., Haywood, A.M., Jonas, J.A., Jost, Anne, Kamae, Youichi, Lohmann, Gerrit, Lunt, D.J., Nisancioglu, K.H., Abe-Ouchi, Ayako, Ramstein, Gilles, Riesselman, C.R., Robinson, M.M., Rosenbloom, N.A., Salzmann, Ulrich, Stepanek, Christian, Strother, S.L., Ueda, Hiroaki, Yan, Qing, and Zhang, Zhongshi, 2013, Sea surface temperature of the mid-Piacenzian ocean-A data-model comparison: Scientific Reports, v. 3. [Also available at https://doi.org/10.1038/srep02013.] 
Dowsett, H.J., Gosnell, L.B., and Poore, R.Z., 1988, Pliocene planktic foraminifer census data from Deep Sea Drilling Project holes 366A, 410, 606, and 646B: U.S. Geological Survey Open-File Report 88-654, 14 p. [Also available at https://doi.org/10.3133/ofr88654.]

Dowsett, H.J., Haywood, A.M., Valdes, P.J., Robinson, M.M., Lunt, D.J., Hill, D.J., Stoll, D.K., and Foley, K.M., 2011, Sea surface temperatures of the mid-Piacenzian warm period - A comparison of PRISM3 and HadCM3: Palaeogeography, Palaeoclimatology, Palaeoecology, v. 309, nos. 1-2, p. 83-91. [Also available at https://doi.org/10.1016/j.palaeo.2011.03.016.]

Dowsett, H.J., and Ishman, S.E., 1995, Middle Pliocene planktonic and benthic foraminifers from the subarctic North PacificSites 883 and 887, chap. 8 of Rea, D.K., Basov, I.A., Scholl, D.W., and Allan, J.F., eds., North Pacific transect * * * sites 881-887* * *: Proceedings of the Ocean Drilling Program, Scientific Results, v. 145, p. 141-156. [Also available at https://doi.org/10.2973/odp.proc.sr.145.150.1995.]

Dowsett, H.J., Ishman, S.E., Verardo, Stacey, and Polanco, E.F., 1993, Pliocene planktic foraminifer census data from Ocean Drilling Program Hole 704A: U.S. Geological Survey Open-File Report 93-304, 7 p.

Dowsett, H.J., and Loubere, Paul, 1992, High resolution late Pliocene sea-surface temperature record from the northeast Atlantic Ocean: Marine Micropaleontology, v. 20, no. 2, p. 91-105. [Also available at https://doi.org/10.1016/0377-8398(92)90001-Z.]

Dowsett, H.J., and Polanco, E.F., 1992, Pliocene planktic foraminifer census data from Deep Sea Drilling Project holes 541 and 546: U.S. Geological Survey Open-File Report 92-418, 4 p. [Also available at https://doi.org/10.3133/ofr92418.]

Dowsett, H.J., and Poore, R.Z., 1988, Quantitative estimates of Pliocene sea-surface temperature-Transfer functions and modern analogs [abs.]: Geological Society of America Abstracts with Programs, v. 20, A254.

Dowsett, H.J., and Poore, R.Z., 1990, A new planktic foraminifer transfer function for estimating Pliocene-Holocene paleoceanographic conditions in the North Atlantic: Marine Micropaleontology, v. 16, nos. 1-2, p. 1-23. [Also available at https://doi.org/10.1016/0377-8398(90)90026-I.]

Dowsett, H.J., and Poore, R.Z., 1991, Pliocene sea surface temperatures of the North Atlantic Ocean at 3.0 Ma: Quaternary Science Reviews, v. 10, nos. 2-3, p. 189-204. [Also available at https://doi.org/10.1016/0277-3791(91)90018-P.]

Dowsett, H.J., and Poore, R.Z., 2000, Data report—Pliocene planktonic foraminifers from the California margin-Site 1021, chap. 5 of Lyle, Mitch, Koizumi, Itaru, Richter, Carl, and Moore, T.C., Jr., eds., California Margin * * * sites 1010-1022 * * *: Proceedings of the Ocean Drilling Program, Scientific Results, v. 167, p. 115-117. [Also available at https://doi.org/10.2973/odp.proc.sr.167.228.2000.]

Dowsett, H.J., and Robinson, M.M., 1998, Application of the modern analogue technique (MAT) of sea surface temperature estimation to middle Pliocene North Pacific planktonic foraminifer assemblages: Palaeontologia Electronica, v. 1, no. 1, article 1.1.3A, 2 p. [Also available at http://palaeo-electronica.org/content/1-1-application-of-modern-analog.]

Dowsett, H.J., and Robinson, M.M., 2007, Mid-Pliocene planktic foraminifer assemblage of the North Atlantic Ocean: Micropaleontology, v. 53, nos. 1-2, p. 105-126. [Also available at https://doi.org/10.2113/gsmicropal.53.1-2.105.]

Dowsett, H.J., and Robinson, M.M., 2009, Mid-Pliocene equatorial Pacific sea surface temperature reconstruction-A multiproxy perspective: Philosophical Transactions of the Royal Society A, v. 367, no. 1886, p. 109-125. [Also available at https://doi.org/10.1098/rsta.2008.0206.]

Dowsett, H.J., Robinson, M.M., and Foley, K.M., 2009, Pliocene three-dimensional global ocean temperature reconstruction: Climate of the Past, v. 5, p. 769-783. [Also available at https://doi.org/10.5194/cp-5-769-2009.]

Dowsett, H.J., Robinson, M.M., and Foley, K.M., 2017, A simple rubric for stratigraphic fidelity $(\beta)$ of Pliocene paleoenvironmental time-series: Stratigraphy, v. 13, no. 4, p. 303-305. [Also available at http://www.micropress.org/microaccess/ stratigraphy/issue-329/article-1999.]

Dowsett, H.J., Robinson, M.M., Haywood, A.M., Hill, D.J., Dolan, A.M., Stoll, D.K., Chan, W.-L., Abe-Ouchi, Ayako, Chandler, M.A., Rosenbloom, N.A., Otto-Bliesner, B.L., Bragg, F.J., Lunt, D.J., Foley, K.M., and Riesselman, C.R., 2012 , Assessing confidence in Pliocene sea surface temperatures to evaluate predictive models: Nature Climate Change, v. 2, p. 365-371. [Also available at https://www.nature.com/articles/nclimate1455.pdfhttps://doi.org/10.1038/NCLIMATE1455.] 
Dowsett, H.J., Robinson, M.M., Stoll, D.K., and Foley, K.M., 2010, Mid-Piacenzian mean annual sea surface temperature analysis for data-model comparisons: Stratigraphy, v. 7, nos. 2-3, p. 189-198. [Also available at http://www.micropress.org/ microaccess/stratigraphy/issue-268/article-1696.]

Dowsett, H.J., Robinson, M.M., Stoll, D.K., Foley, K.M., Johnson, A.L.A., Williams, M., and Riesselman, C.R., 2013, The PRISM (Pliocene palaeoclimate) reconstruction - Time for a paradigm shift: Philosophical Transactions of the Royal Society A, v. 371, no. 2001, 24 p. [Also available at https://doi.org/10.1098/rsta.2012.0524.]

Dowsett, H.J., and West, S.M., 1992, Pliocene planktic foraminifer census data from Deep Sea Drilling Project hole 607 and Ocean Drilling Program hole 661A: U.S. Geological Survey Open-File Report 92-413, 4 p. [Also available at https://doi.org/10.3133/ofr92413.]

Dowsett, H.J., and Wiggs, L.B., 1992, Planktonic foraminiferal assemblage of the Yorktown Formation, Virginia, USA: Micropaleontology, v. 38, no. 1, p. 75-86. [Also available at https://doi.org/10.2307/1485844.]

Einarsson, T., and Albertsson, K.J., 1988, The glacial history of Iceland during the past three million years: Philosophical Transactions of the Royal Society of London B, v. 318, no. 1191, p. 637-644. [Also available at https://doi.org/10.1098/ rstb.1988.0027.]

Eiríksson, Jón, Gudmundsson, A.I., Kristjánsson, Leó, and Gunnarsson, Karl, 1990, Palaeomagnetism of Pliocene-Pleistocene sediments and lava flows on Tjörnes and Flatey, North Iceland: Boreas, v. 19, no. 1, p. 39-55. [Also available at https://doi.org/10.1111/j.1502-3885.1990.tb00420.x.]

Farrell, J.W., Clemens, S.C., and Gromet, L.P., 1995, Improved chronostratigraphic reference curve of late Neogene seawater ${ }^{87} \mathrm{Sr} /{ }^{86} \mathrm{Sr}$ : Geology, v. 23, no. 5, p. 403-406. [Also available at https://doi.org/10.1130/0091-7613(1995)023<0403:ICRCOL $>2$ .3.CO;2.]

Farrell, J.W., and Janecek, T.R., 1991, Late Neogene paleoceanography and paleoclimatology of the northeast Indian Ocean (site 758), chap. 15 of Weissel, Jeffrey, Alt, Jeffrey, Peirce, John, and Taylor, Elliott, eds., Broken Ridge and Ninetyeast Ridge $* * *$ sites $752-758 * * *$ : Proceedings of the Ocean Drilling Program, Scientific Results, v. 121, p. 297-355. [Also available at https://doi.org/10.2973/odp.proc.sr.121.124.1991.]

Fleming, R.F., and Barron, J.A., 1996, Evidence of Pliocene Nothofagus in Antarctica from Pliocene marine sedimentary deposits (DSDP Site 274): Marine Micropaleontology, v. 27, nos. 1-4, p. 227-236. [Also available at https://doi.org/10.1016/03778398(95)00062-3.]

Foley, K.M., and Dowsett, H.J., 1992, Pliocene planktic foraminifer census data from Ocean Drilling Program holes 667 and 659A: U.S. Geological Survey Open-File Report 92-434, 8 p. [Also available at https://doi.org/10.3133/ofr92434.]

Foley, K., Robinson, M., Dowsett, H.J., Poore, R.Z., Stoll, D., Polanco, E., Wiggs, L., Caballero, R., Verardo, S., Strother, S., West, S., Lutz, B., and Brown, S., 2015, A global planktic foraminifer census data set for the Pliocene ocean: National Climatic Data Center, Paleoclimatology Data web page. [Also available at https://www.ncdc.noaa.gov/paleo-search/ study/19281.]

Gladenkov, Y.B., Barinov, K.B., Basilian, A.E., and Cronin, T.M., 1991, Stratigraphy and paleoceanography of Pliocene deposits of Karaginsky Island, eastern Kamchatka, U.S.S.R.: Quaternary Science Reviews, v. 10, nos. 2-3, p. 239-245. [Also available at https://doi.org/10.1016/0277-3791(91)90022-M.]

Hailwood, E.A., and Clement, B.M., 1991, Magnetostratigraphy of sites 699 and 700, East Georgia Basin, chap. 19 of Ciesielski, P.F., Kristoffersen, Yngve, Clement, Bradford, and Moore, T.C., eds., Subantarctic South Atlantic * * * sites 698-704***: Proceedings Ocean Drilling Program, Scientific Results, v. 114, p. 331-357. [Also available at https://doi.org/10.2973/odp.proc.sr.114.155.1991.]

Hall, I.R., McCave, I.N., Shackleton, N.J., Weedon, G.P., and Harris, S.E., 2001, Intensified deep Pacific inflow and ventilation in Pleistocene glacial times: Nature, v. 412, p. 809-812. [Also available at https://doi.org/10.1038/35090552.]

Harwood, D.M., Lazarus, D.B., Abelmann, A., Aubry, M.-P., Berggren, W.A., Heider, F., Inokuchi, H., Maruyama, T., McCartney, K., Wei, W., and Wise, S.W., Jr., 1992, Neogene integrated magnetobiostratigraphy of the central Kerguelen Plateau, Leg 120, chap. 57 of Wise, S.W., Jr., Palmer Julson, A.A., Schlich, Roland, and Thomas, Ellen, eds., Central Kerguelen Plateau * * * sites 747-751***: Proceedings Ocean Drilling Program, Scientific Results, v. 120, p. 1031-1052. [Also available at https://doi.org/10.2973/odp.proc.sr.120.185.1992.] 
Harwood, D.M., and Maruyama, Toshiaki, 1992, Middle Eocene to Pleistocene diatom biostratigraphy of Southern Ocean sediments from the Kerguelen Plateau, Leg 120, chap. 38 of Wise, S.W., Jr., Palmer Julson, A.A., Schlich, Roland, and Thomas, Ellen, eds., Central Kerguelen Plateau * * * sites 747-751***: Proceedings Ocean Drilling Program, Scientific Results, v. 120, p. 683-733. [Also available at https://doi.org/10.2973/odp.proc.sr.120.160.1992.]

Hay, W.W., 1972, Probabilistic stratigraphy: Eclogae Geologicae Helvetiae, v. 65, no. 2, p. 255-266. [Also available at https://doi.org/10.5169/seals-164090.]

Hays, P.E., Pisias, N.G., and Roelofs, A.K., 1989, Paleoceanography of the eastern equatorial Pacific during the PlioceneA high-resolution radiolarian study: Paleoceanography, v. 4, no. 1, p. 57-73. [Also available at https://doi.org/10.1029/ PA004i001p00057.]

Haywood, A.M., Chandler, M.A., Valdes, P.J., Salzmann, Ulrich, Lunt, D.J., and Dowsett, H.J., 2009, Comparison of midPliocene climate predictions produced by the HadAM3 and GCMAM3 general circulation models: Global and Planetary Change, v. 66, nos. 3-4, p. 208-224. [Also available at https://doi.org/10.1016/j.gloplacha.2008.12.014.]

Haywood, A.M., Dowsett, H.J., Otto-Bliesner, B., Chandler, M.A., Dolan, A.M., Hill, D.J., Lunt, D.J., Robinson, M.M., Rosenbloom, N., Salzmann, U., and Sohl, L.E., 2010, Pliocene Model Intercomparison Project (PlioMIP)—Experimental design and boundary conditions (Experiment 1): Geoscientific Model Development, v. 3, p. 227-242. [Also available at https://doi.org/10.5194/gmd-3-227-2010.]

Haywood, A.M., Dowsett, H.J., Robinson, M.M., Stoll, D.K., Dolan, A.M., Lunt, D.J., Otto-Bliesner, B., and Chandler, M.A., 2011, Pliocene Model Intercomparison Project (PlioMIP) - Experimental design and boundary conditions (Experiment 2): Geoscientific Model Development, v. 4, p. 571-577. [Also available at https://doi.org/10.5194/gmd-4-571-2011.]

Haywood, A.M., Hill, D.J., Dolan, A.M., Otto-Bliesner, B.L., Bragg, F., Chan, W.-L., Chandler, M.A., Contoux, C., Dowsett, H.J., Jost, A., Kamae, Y., Lohmann, G., Lunt, D.J., Abe-Ouchi, A., Pickering, S.J., Ramstein, G., Rosenbloom, N.A., Salzmann, U., Sohl, L., Stepanek, C., Ueda, H., Yan, Q., and Zhang, Z., 2013, Large-scale features of Pliocene climateResults from the Pliocene Model Intercomparison Project: Climate of the Past, v. 9, no. 1, p. 191-209. [Also available at http://doi.org/10.5194/cpd-8-2969-2012.]

Haywood, A.M., and Valdes, P.J., 2004, Modeling Pliocene warmth - Contribution of atmosphere, oceans and cryosphere: Earth and Planetary Science Letters, v. 218, nos. 3-4, p. 363-377. [Also available at https://doi.org/10.1016/S0012-821X(03)00685$\mathrm{X}$.

Herbert, Timothy, Dowsett, H.J., and Caballero-Gill, R.P., 2015, A new model of orbital pacing for Pliocene glaciations [abs.]: American Geophysical Union, 2015 Fall Meeting, San Francisco, Calif., December 14-18, 2015, abstract PP52A-07. [Also available at http://abstractsearch.agu.org/meetings/2015/FM/PP52A-07.html.]

Herbert, T.D., Peterson, L.C., Lawrence, K.T., and Liu, Zhonghui, 2010, Tropical ocean temperatures over the past 3.5 million years: Science, v. 328, no. 5985, p. 1530-1534. [Also available at https://doi.org/10.1126/science.1185435.]

Hodell, D.A., and Ciesielski, P.F., 1991, Stable isotopic and carbonate stratigraphy of the late Pliocene and Pleistocene of hole 704A-Eastern subantarctic South Atlantic, chap. 23 of Ciesielski, P.F., Kristoffersen, Yngve, Clement, Bradford, and Moore, T.C., eds., Subantarctic South Atlantic *** Sites 698-704***: Proceedings Ocean Drilling Program, Scientific Results, v. 114, p. 409-435. [Also available at https://doi.org/10.2973/odp.proc.sr.114.150.1991.]

Hodell, D.A., and Venz, Kathryn, 1992, Toward a high-resolution stable isotopic record of the Southern Ocean during the Pliocene-Pleistocene (4.8-0.8 Ma), in Kennett, J.P., and Warkne, D.A., eds., The Antarctic paleoenvironment-A perspective on global change-Part one: Antarctic Research Series, v. 56, p. 265-310. [Also available at https://doi.org/10.1029/AR056.]

Hutson, W.H., 1980, The Agulhas Current during the late Pleistocene-Analysis of modern faunal analogs: Science, v. 207, no. 4426, p. 64-66. [Also available at https://doi.org/10.1126/science.207.4426.64.]

Ikeya, Noriyuki, and Cronin, T.M., 1993, Quantitative analysis of ostracoda and water masses around Japan-Application to Pliocene and Pleistocene paleoceanography: Micropaleontology, v. 39, no. 3, p. 263-281. [Also available at https://doi.org/10.2307/1485900.] 
Jansen, Eystein, Mayer, L.A., Backman, Jan, Leckie, R.M., and Takayama, Toshiaki, 1993, Evolution of Pliocene climate cyclicity at hole 806B (5-2 Ma) - Oxygen isotope record, chap. 20 of Berger, W.H., Kroenke, L.W., Janecek, T.R., and Sliter, W.V., eds., Ontong Java Plateau * * * sites 803-807***: Proceedings Ocean Drilling Program, Scientific Results, v. 130, p. 349-362. [Also available at https://doi.org/10.2973/odp.proc.sr.130.028.1993.]

Jenkins, D.G., 1992a, Predicting extinctions of some extant planktic foraminifera: Marine Micropaleontology, v. 19, no. 3 , p. 239-243. [Also available at https://doi.org/10.1016/0377-8398(92)90030-N.]

Jenkins, D.G., 1992b, The paleogeography, evolution and extinction of late Miocene-Pleistocene planktonic foraminifera from the southwest Pacific, in Ishizaki, Kunihiro, and Saito, Tsunemasa, eds., Centenary of Japanese micropaleontologyContributed papers in honor of Professor Yokichi Takayanagi: Tokyo, Japan, Terra Scientific Publishing Company, p. 27-35. [Also available at http://www.terrapub.co.jp/e-library/cjm/.]

Jenkins, D.G., and Houghton, S.D., 1989, Late Miocene to Pleistocene planktonic foraminifers from Ocean Drilling Program site 677, Panama Basin, chap. 24 of Becker, Keir, Merrill, R.B., Sakai, Hitoshi, and Sancetta, C.B., eds., Costa Rica Rift $* * *$ sites 504, 677, and $768 * * *$ : Proceedings Ocean Drilling Program, Scientific Results, v. 111, p. 289-293. [Also available at https://doi.org/10.2973/odp.proc.sr.111.147.1989.]

Johnson, A.L.A., Hickson, J.A., Bird, Annemarie, Schöne, B.R., Balson, P.S., Heaton, T.H.E., and Williams, Mark, 2009, Comparative sclerochronology of modern and mid-Pliocene (c. 3.5 Ma) Aequipecten opercularis (Mollusca, Bivalvia) - An insight into past and future climate change in the north-east Atlantic region: Palaeogeography, Palaeoclimatology, Palaeoecology, v. 284, nos. 3-4, p. 164-179. [Also available at https://doi.org/10.1016/j.palaeo.2009.09.022.]

Joyce, J.E., Tjalsma, L.R.C., and Prutzman, J.M., 1990, High-resolution planktic stable isotope record and spectral analysis for the last 5.35 M.Y.-Ocean Drilling Program site 625, northeast Gulf of Mexico: Paleoceanography, v. 5, no. 4, p. 507-529. [Also available at http://doi.org/10.1029/PA005i004p00507.]

Karas, Cyrus, Nürnberg, Dirk, Tiedemann, Ralf, and Garbe-Schönberg, Dieter, 2011, Pliocene Indonesian Throughflow and Leeuwin Current dynamics-Implications for Indian Ocean polar heat flux: Paleoceanography, v. 26, no. 2, article PA2217, 9 p. [Also available at https://doi.org/10.1029/2010PA001949.]

Keigwin, L.D., Jr., 1982, Neogene planktonic foraminifers from Deep Sea Drilling Project sites 502 and 503, chap. 5 of Volume LXVIII covering Leg 68 of the cruises of the drilling vessel Glomar Challenger, Willemstad Curaçao, to Guayaquil, Ecuador, August-September, 1979: Initial Reports of the Deep Sea Drilling Project, v. 68, p. 269-288. [Also available at https://doi.org/10.2973/dsdp.proc.68.105.1982.]

Keller, Gerta, 1978, Late Neogene biostratigraphy and paleoceanography of DSDP site 310 central North Pacific and correlation with the Southwest Pacific: Marine Micropaleontology, v. 3, no. 2, p. 97-119. [Also available at https://doi.org/10.1016/03778398(78)90001-4.]

Kent, D.V., and Spariosu, D.J., 1982, Magnetostratigraphy of Caribbean site 502 hydraulic piston cores, chap. 16 of Volume LXVIII covering Leg 68 of the cruises of the drilling vessel Glomar Challenger, Willemstad, Curaçao, to Guayaquil, Ecuador, August-September, 1979: Initial Reports of the Deep Sea Drilling Project, v. 68, p. 419-433. [Also available at https://doi.org/10.2973/dsdp.proc.68.116.1982.]

Koizumi, Itaru, 1985, Diatom biochronology for the late Cenozoic northwest Pacific: Journal of the Geologic Society of Japan, v. 91, no. 3, p. 195-211. [Also available at https://doi.org/10.5575/geosoc.91.195.]

Koizumi, Itaru, and Tanimura, Yoshihiro, 1985, Neogene diatom biostratigraphy of the middle latitude western North Pacific, Deep Sea Drilling Project Leg 86, chap. 9 of Volume LXXXVI covering Leg 86 of the cruises of the drilling vessel Glomar Challenger, Honolulu, Hawaii, to Yokohama, Japan, May-June 1982: Initial Reports of the Deep Sea Drilling Project, v. 86, p. 269-300. [Also available at https://doi.org/10.2973/dsdp.proc.86.109.1985.]

Krantz, D.E., 1991, A chronology of Pliocene sea-level fluctuations-The U.S. Middle Atlantic Coastal Plain record: Quaternary Science Reviews, v. 10, p. 163-174. [Also available at https://doi.org/10.1016/0277-3791(91)90016-N.] 
Kroon, D., Williams, T., Pirmez, C., Spezzaferri, S., Sato, T., and Wright, J.D., 2000, Coupled early Pliocene-middle Miocene bio-cyclostratigraphy of site 1006 reveals orbitally induced cyclicity patterns of Great Bahama Bank carbonate production, chap. 15 of Swart, P.K., Eberli, G.P., Malone, M.J., and Sarg, J.F., eds., Bahamas transect * * * sites 1003-1009* * *: Proceedings of the Ocean Drilling Program, Scientific Results, v. 166, p. 155-166. [Also available at https://doi.org/10.2973/ odp.proc.sr.166.127.2000.]

Kucera, M., and Kennett, J.P., 2000, Biochronology and evolutionary implications of Late Neogene California margin planktic foraminiferal events: Marine Micropaleontology, v. 40, nos. 1-2, p. 67-81. [Also available at https://doi.org/10.1016/S03778398(00)00029-3.]

Lacasse, Christian, and van den Bogaard, Paul, 2002, Enhanced airborne dispersal of silicic tephras during the onset of Northern Hemisphere glaciations, from 6 to 0 Ma records of explosive volcanism and climate change in the subpolar North Atlantic: Geology, v. 30, no. 7 p. 623-626. [Also available at https://doi.org/10.1130/0091-7613(2002)030<0623:EADOST>2.0.CO;2.]

Lisiecki, L.E., and Raymo, M.E., 2005, A Pliocene-Pleistocene stack of 57 globally distributed benthic $\delta^{18} \mathrm{O}$ records: Paleoceanography, v. 20, no. 1, p. 1-17. [Also available at https://doi.org/10.1029/2004PA001071.]

Loubere, Paul, and Jakiel, Richard, 1985, A sedimentological, faunal, and isotopic record of the middle-to-late Pliocene transition in the northeastern Atlantic, Deep Sea Drilling Project site 548, chap. 11 of Volume LXXX, Part 1 covering Leg 80 of the cruises of the drilling vessel Glomar Challenger, Brest, France, to Southampton, United Kingdom, June-July, 1981: Initial Reports of the Deep Sea Drilling Project, v. 80, p, 473-488. [Also available at https://doi.org/10.2973/dsdp.proc.80.111.1985.]

Loubere, Paul, and Moss, Kevin, 1986, Late Pliocene climatic change and the onset of Northern Hemisphere glaciation as recorded in the northeast Atlantic Ocean: Geological Society of America Bulletin, v. 97, p. 818-828. [Also available at https://doi.org/10.1130/0016-7606(1986)97<818:LPCCAT>2.0.CO;2.]

Lunt, D.J., Haywood, A.M., Schmidt, G.A., Salzmann, Ulrich, Valdes, P.J., and Dowsett, H.J., 2010, Earth system sensitivity inferred from Pliocene modelling and data: Nature Geoscience, v. 3, p. 60-64. [Also available at https://doi.org/10.1038/ ngeo706.]

Lutz, B.P., 2011a, Late Neogene paleoceanography of the low-latitude Northern Hemisphere-Implications for climate and ocean circulation in a warmer world: Carbondale, Southern Illinois University, Ph.D. dissertation, 201 p.

Lutz, B.P., 2011b, Shifts in North Atlantic planktic foraminifer biogeography and subtropical gyre circulation during the midPiacenzian warm period: Marine Micropaleontology, v. 80, nos. 3-4, p. 125-149. [Also available at https://doi.org/10.1016/ j.marmicro.2011.06.006.]

Ma'alouleh, Kayed, and Moullade, Michel, 1986, Biostratigraphic and paleoenvironmental study of Neogene and Quaternary planktonic foraminifers from the lower continental rise of the New Jersey margin (western North Atlantic), Deep Sea Drilling Project Leg 93, site 603, chap. 7 of Volume XCIII, Part 1 covering Leg 93 of the cruises of the drilling vessel Glomar Challenger, Norfolk, Virginia, to Norfolk, Virginia, May-June, 1983: Initial Reports of the Deep Sea Drilling Project, v. 93, p. 481-491. [Also available at https://doi.org/10.2973/dsdp.proc.93.107.1987.]

Masson-Delmotte, Valérie, Schulz, Michael, Abe-Ouchi, Ayako, Beer, Jürg, Ganopolski, Andrey, González Rouco, J.F., Jansen, Eystein, Lambeck, Kurt, Luterbacher, Jürg, Naish, Tim, Osborn, Timothy, Otto-Bliesner, Bette, Quinn, Terrence, Ramesh, Rengaswamy, Rojas, Maisa, Shao, XueMei, and Timmermann, Axel, 2013, Information from paleoclimate archives, chap. 5 of Stocker, T.F., Qin, Dahe, Plattner, G.-K., Tignor, M.M.B., Allen, S.K., Boschung, Judith, Nauels, Alexander, Xia, Yu, Bex, Vincent, and Midgley, P.M., eds., Climate change 2013-The physical science basis, Contribution of Working Group I to the Fifth Assessment Report of the Intergovernmental Panel on Climate Change: Cambridge, United Kingdom, Cambridge University Press, p. 383-464. [Also available at http://www.ipcc.ch/report/ar5/wg1/.]

Mastrandrea, M.D., Field, C.B., Stocker, T.F., Edenhofer, Ottmar, Ebi, K.L., Frame, D.J., Held, Hermann, Kriegler, Elmar, Mach, K.J., Matschoss, P.R., Plattner, G.-K., Yohe, G.W., and Zwiers, F.W., 2010, Guidance note for lead authors of the IPCC Fifth Assessment Report on consistent treatment of uncertainties: Intergovernmental Panel on Climate Change, 4 p. [Also available at https://www.ipcc.ch/pdf/supporting-material/uncertainty-guidance-note.pdf.]

Matthews, J.V., Jr., and Ovenden, L.E., 1990, Late Tertiary plant macrofossils from localities in Arctic/Subarctic North America-A review of the data: Arctic, v. 43, no. 4, p. 364-392. [Also available at http://www.jstor.org/stable/40510961.] 
Mattingsdal, Rune, Knies, Jochen, Andreassen, Karin, Fabian, Karl, Husum, Katrine, Grøsfjeld, Kari, and De Schepper, Stijn, 2014, A new 6 Myr stratigraphic framework for the Atlantic-Arctic Gateway: Quaternary Science Reviews, v. 92, p. 170-178. [Also available at https://doi.org/10.1016/j.quascirev.2013.08.022.]

Miller, K.G., Wright, J.D., Browning, J.V., Kulpecz, Andrew, Kominz, Michelle, Naish, T.R., Cramer, B.S., Rosenthal, Yair, Peltier, W.R., and Sosdian, Sindia, 2012, The high tide of the warm Pliocene-Implications of global sea level for Antarctic deglaciation: Geology, v. 40, no. 5, p. 407-410. [Also available at https://doi.org/10.1130/G32869.1.]

Müller, Carla, 1985, Biostratigraphic and paleoenvironmental interpretation of the Goban Spur region based on a study of calcareous nannoplankton, chap. 17 of Volume LXXX, Part 1 covering Leg 80 of the cruises of the drilling vessel Glomar Challenger, Brest, France, to Southampton, United Kingdom, June-July, 1981: Initial Reports of the Deep Sea Drilling Project, v. 80, p. 573-599. [Also available at https://doi.org/10.2973/dsdp.proc.80.117.1985.]

Muza, J.P., Wise, S.W., Jr., and Covington, J.M., 1986, Neogene calcareous nannofossils from Deep Sea Drilling Project site 603, lower continental rise, western North Atlantic - Biostratigraphy and correlations with magnetic and seismic stratigraphy, chap. 15 of Volume XCIII, Part 1 covering Leg 93 of the cruises of the drilling vessel Glomar Challenger, Norfolk, Virginia, to Norfolk, Virginia, May-June, 1983: Initial Reports of the Deep Sea Drilling Project, v. 93, p. 593-616. [Also available at https://doi.org/10.2973/dsdp.proc.93.115.1987.]

Myhre, A.M., Thiede, J., Firth, J.V., Ahagon, Naokazu, Black, K.S., Bloemendal, Jan, Brass, G.W., Bristow, J.F., Chow, Nancy, Cremer, Michel, Davis, Linda, Flower, Benjamin, Fronval, Torben, Hood, Julie, Hull, Donna, Koç, Nalan, Larsen, Birger, Lyle, M.W., McManus, Jerry, O’Connell, Suzanne, Osterman, Lisa Ellen, Rack, F.R., Sato, Tokiyuki, Scherer, R.P., Spiegler, Dorothee, Stein, Ruediger, Tadross, Mark, Wells, Stephen, Williamson, David, Witte, Bill, and Wolf-Welling, Thomas, 1995, North Atlantic-Arctic Gateways * * * sites 907-913***: Proceedings of the Ocean Drilling Program, Initial Reports, v. 151. [Also available at https://doi.org/10.2973/odp.proc.ir.151.1995.]

Naish, T.R., Abbott, S.T., Alloway, B.V., Beu, A.G., Carter, R.M., Edwards, A.R., Journeaux, T.D., Kampa, P.J.J., Pillans, B.J., Saul, Gordon, and Woolfe, K.J., 1998, Astronomical calibration of a Southern Hemisphere Plio-Pleistocene reference section, Wanganui Basin, New Zealand: Quaternary Science Reviews, v. 17, no. 8, p. 695-710. [Also available at https://doi.org/10.1016/S0277-3791(97)00075-9.]

Naish, T., Powell, R., Levy, R., Wilson, G., Scherer, R., Talarico, F., Krissek, L., Niessen, F., Pompilio, M., Wilson, T., Carter, L., DeConto, R., Huybers, P., McKay, R., Pollard, D., Ross, J., Winter, D., Barrett, P., Browne, G., Cody, R., Cowan, E., Crampton, J., Dunbar, G., Dunbar, N., Florindo, F., Gebhardt, C., Graham, I., Hannah, M., Hansaraj, D., Harwood, D., Helling, D., Henrys, S., Hinnov, L., Kuhn, G., Kyle, P., Läufer, A., Maffioli, P., Magens, D., Mandernack, K., McIntosh, W., Millan, C., Morin, R., Ohneiser, C., Paulsen, T., Persico, D., Raine, I., Reed, J., Riesselman, C., Sagnotti, L., Schmitt, D., Sjunneskog, C., Strong, P., Taviani, M., Vogel, S., Wilch, T., and Williams, T., 2009, Obliquity-paced Pliocene West Antarctic ice sheet oscillations: Nature, v. 458, p. 322-328. [Also available at https://doi.org/10.1038/nature07867.]

Polanco, Emerson, and Dowsett, Harry, 1993, Pliocene planktic foraminifer census data from Deep Sea Drilling Project hole 463 and Ocean Drilling Program hole 769B: U.S. Geological Survey Open-File Report 93-308, 6 p. [Also available at https://doi.org/10.3133/ofr93308.]

Poore, R.Z., 1978, Oligocene through Quaternary planktonic foraminiferal biostratigraphy of the North Atlantic —DSDP Leg 49, chap. 15 of Volume XLIX covering Leg 49 of the cruises of the drilling vessel Glomar Challenger, Aberdeen, Scotland, to Funchal, Madeira, July-September 1976: Initial Reports of the Deep Sea Drilling Project, v. 49, p. 447-517. [Also available at https://doi.org/10.2973/dsdp.proc.49.115.1979.]

Poore, R.Z., 1991, Pliocene planktic foraminifer census data from Deep Sea Drilling Project hole 603C: U.S. Geological Survey Open-File Report 91-309, 7 p. [Also available at https://doi.org/10.3133/ofr91309.]

Poore, R.Z., 1999, Mid-Pliocene planktic foraminifers and environmental estimates from northeastern Pacific Deep Sea Drilling Project site 36, in Wrenn, J.H., Suc, J.-P., and Leroy, S.A.G., eds., The Pliocene-Time of change: Dallas, Tex., American Association of Stratigraphic Palynologists Foundation, p. 199-208.

Poore, R.Z., and Gosnell, L.B., 1990, Quantitative planktic foraminifer record from Caribbean DSDP Site 502-3 to 2 Ma: Eos Transactions American Geophysical Union, v. 71, no. 43, p. 1383. 
Poore, R.Z., Steinmetz, J.C., and Schrader, H.-J., 1978, Biostratigraphic summary of DSDP Leg 49, chap. 39 of Volume XLIX covering Leg 49 of the cruises of the drilling vessel Glomar Challenger, Aberdeen, Scotland, to Funchal, Madeira, July-September 1976: Initial Reports of the Deep Sea Drilling Project, v. 49, p. 851-858. [Also available at https://doi.org/ 10.2973/dsdp.proc.49.139.1979.]

PRISM Project Members, 1996, Pliocene planktic foraminiferal census data from 19 core sites in the North Atlantic region: U.S. Geological Survey Open-File Report 96-669, 8 p. [Also available at https://pubs.usgs.gov/of/1996/of96-669/.]

Pujol, Claude, and Duprat, Josette, 1985, Quaternary and Pliocene planktonic foraminifers of the northeastern Atlantic (Goban Spur), Deep Sea Drilling Project Leg 80, chap. 25 of Volume LXXX, Part 1 covering Leg 80 of the cruises of the drilling vessel Glomar Challenger, Brest, France, to Southampton, United Kingdom, June-July, 1981: Initial Reports of the Deep Sea Drilling Project, v. 80, p. 683-723. [Also available at https://doi.org/10.2973/dsdp.proc.80.125.1985.]

Ravelo, A.C., Andreasen, D.H., Lyle, Mitchell, Olivarez Lyle, Annette, and Wara, M.W., 2004, Regional climate shifts caused by gradual global cooling in the Pliocene epoch: Nature, v. 429, no. 6989, p. 263-267. [Also available at http://doi.org/10.1038/ nature02567.]

Raymo, M.E., Hearty, P., DeConto, R., O’Leary, M., Dowsett, H.J., Robinson, M.M., and Mitrovica, J.X., 2009, PLIOMAXPliocene maximum sea level project: PAGES News, v. 17, no. 2, p. 58-59. [Also available at http://www.pages-igbp.org/ download/docs/newsletter/2009-2/Special_section/science_highlights/Maureen_2009-2(58-59).pdf.]

Raymo, M.E., Ruddiman, W.F., Backman, J., Clement, B.M., and Martinson, D.G., 1989, Late Pliocene variation in Northern Hemisphere ice sheets and North Atlantic deep water circulation: Paleoceanography, v. 4, no. 4, p. 413-446. [Also available at https://doi.org/10.1029/PA004i004p00413.]

Riesselman, C.R., and Dunbar, R.B., 2013, Diatom evidence for the onset of Pliocene cooling from AND-1B, McMurdo Sound, Antarctica: Palaeogeography, Palaeoclimatology, Palaeoecology, v. 369, p. 136-153. [Also available at https://doi.org/10.1016/j.palaeo.2012.10.014.]

Rio, Domenico, Fornaciari, Eliana, and Raffi, Isabella, 1990, Late Oligocene through early Pleistocene calcareous nannofossils from western equatorial Indian Ocean (Leg 115), chap. 15 of Duncan, R.A., Backman, Jan, Dunbar, R.B., and Peterson, L.C., eds., Mascarene Plateau $* * *$ sites $705-716 * * *$ : Proceedings of the Ocean Drilling Program, Scientific Results, v. 115, p. 175-235. [Also available at https://doi.org/10.2973/odp.proc.sr.115.152.1990.]

Robinson, Marci, Caballero, Rocio, Pohlman, Emily, Herbert, Timothy, Peck, Victoria, and Dowsett, Harry, 2008, Mid-Pliocene planktic foraminifer census data and alkenone unsaturation indices from Ocean Drilling Program hole 677A: U.S. Geological Survey Data Series 353, accessed June 12, 2008, at https://pubs.usgs.gov/ds/353/.

Robinson, M.M., 2009, New quantitative evidence of extreme warmth in the Pliocene Arctic: Stratigraphy, v. 6, no. 4, p. 265-275. [Also available at http://www.micropress.org/micropen2/articles/1/6/30832_articles_article_file_1651.pdf.]

Robinson, M.M., and Dowsett, H.J., 1996, Pliocene planktic foraminifer census data from DSDP site 592, southwest Pacific Ocean: U.S. Geological Survey Open-File Report 96-544, 6 p. [Also available at https://doi.org/10.3133/ofr96544.]

Robinson, M.M., Dowsett, H.J., Dwyer, G.S., and Lawrence, K.T., 2008, Reevaluation of mid-Pliocene North Atlantic sea surface temperatures: Paleoceanography, v. 23, no. 3, article PA3213, 9 p. [Also available at https://doi.org/ 10.1029/2008PA001608.]

Robinson, M.M., Dowsett, H.J., and Stoll, D.K., 2018, Sea surface temperature estimates for the mid-Piacenzian Indian OceanOcean Drilling Program sites 709, 716, 722, 754, 757, 758 and 763: U.S. Geological Survey Open-File Report 2017-1158, 14 p., accessed January 30, 2018, at https://doi.org/10.3133/ofr20171158.

Robinson, M.M., Valdes, P.J., Haywood, A.M., Dowsett, H.J., Hill, D.J., and Jones, S.M., 2011, Bathymetric controls on Pliocene North Atlantic and Arctic sea surface temperature and deepwater production: Palaeogeography, Palaeoclimatology, Palaeoecology, v. 309, nos. 1-2, p. 92-97. [Also available at https://doi.org/10.1016/j.palaeo.2011.01.004.]

Sabaa, A.T., Sikes, E.L., Hayward, B.W., and Howard, W.R., 2004, Pliocene sea surface temperature changes in ODP site 1125, Chatham Rise, east of New Zealand: Marine Geology, v. 205, nos. 1-4, p. 113-125. [Also available at https://doi.org/10.1016/ S0025-3227(04)00020-9.] 
Sancetta, Constance, and Silvestri, ShayMaria, 1986, Pliocene-Pleistocene evolution of the North Pacific Ocean-Atmosphere system, interpreted from fossil diatoms: Paleoceanography, v. 1, no. 2, p. 163-180. [Also available at https://doi.org/10.1029/ PA001i002p00163.]

Sato, Tokiyuki, and Kameo, Koji, 1996, Pliocene to Quaternary calcareous nannofossil biostratigraphy of the Arctic Ocean, with reference to late Pliocene glaciation, chap. 3 of Thiede, Jörn, Myhre, A.M., Firth, J.V., Johnson, G.L., and Ruddiman, W.F., eds., North Atlantic-Arctic Gateways * * * sites 907-913***: Proceedings of the Ocean Drilling Program, Scientific Results, v. 151, p. 39-59. [Also available at https://doi.org/10.2973/odp.proc.sr.151.112.1996.]

Shackleton, N.J., Crowhurst, S., Hagelberg, T., Pisias, N.G., and Schneider, D.A., 1995, A new late Neogene time scaleApplication to Leg 138 sites, chap. 43 of Mayer, L.A., Pisias, N.G., Palmer-Julson, Amanda, and van Andel, T.H., eds., Eastern equatorial Pacific *** sites 844-854***: Proceedings of the Ocean Drilling Program, Scientific Results, v. 138, p. 73-101. [Also available at https://doi.org/10.2973/odp.proc.sr.138.106.1995.]

Shackleton, N.J., and Hall, M.A., 1990, Pliocene oxygen isotope stratigraphy of hole 709C, chap. 28 of Duncan, R.A., Backman, Jan, Dunbar, R.B., and Peterson, L.C., eds., Mascarene Plateau * * * sites 705-716***: Proceedings of the Ocean Drilling Program, Scientific Results, v. 115, p. 529-538. [Also available at https://doi.org/10.2973/odp.proc.sr.115.174.1990.]

Shipboard Scientific Party, 1972, Site 111, chap. 3 of Volume XII covering Leg 12 of the cruises of the drilling vessel Glomar Challenger, Boston, Massachusetts, to Lisbon, Portugal, June-August 1970: Initial Reports of the Deep Sea Drilling Project, v. 12, p. 33-159. [Also available at https://doi.org/10.2973/dsdp.proc.12.103.1972.]

Shipboard Scientific Party, 1983, Site 606, chap. 2 of Volume XCIV, Part 1 covering Leg 94 of the cruises of the drilling vessel Glomar Challenger, Norfolk, Virginia, to St. John's, Newfoundland, June-August 1983: Initial Reports of the Deep Sea Drilling Project, v. 94, p. 763-793. [Also available at https://doi.org/10.2973/dsdp.proc.94.102.1987.]

Shipboard Scientific Party, 1984, Site 546, chap. 4 of Volume LXXIX covering Leg 79 of the cruises of the drilling vessel Glomar Challenger, Las Palmas, Grand Canary Island, to Brest, France, April-May 1981: Initial Reports of the Deep Sea Drilling Project, v. 79, p. 179-221. [Also available at https://doi.org/10.2973/dsdp.proc.79.104.1984.]

Shipboard Scientific Party, 1988a, Site 672, chap. 5 of Barbados Ridge * * * sites 671-676* * * Proceedings of the Ocean Drilling Program, Initial Reports (Pt. A), v. 110, p. 205-310. [Also available at https://doi.org/10.2973/odp.proc. ir.110.106.1988.]

Shipboard Scientific Party, 1988b, Site 709, chap. 7 of Mascarene Plateau $* * *$ sites 705-716* * *: Proceedings of the Ocean Drilling Program, Initial Reports, v. 115, p. 459-588. [Also available at https://doi.org/10.2973/odp.proc.ir.115.108.1988.]

Shipboard Scientific Party, 1988c, Site 716, chap. 13 of Mascarene Plateau * * * sites 705-716* * *: Proceedings of the Ocean Drilling Program, Initial Reports, v. 115, p. 1005-1073. [Also available at https://doi.org/10.2973/odp.proc. ir.115.114.1988.]

Shipboard Scientific Party, 1988d, Sites 677 and 678, chap. 4 of Costa Rica Rift * * * sites 504, 677, $678 * * *$ * Proceedings of the Ocean Drilling Program, Initial Reports (Pt. A), v. 111, p. 253-346. [Also available at https://doi.org/10.2973/odp.proc. ir.111.104.1988.]

Shipboard Scientific Party, 1989a, Site 722, chap. 10 of Oman Margin/Neogene package * * * sites 720-731 * * *: Proceedings of the Ocean Drilling Program, Initial Reports, v. 117, p. 255-317. [Also available at https://doi.org/10.2973/odp.proc. ir.117.107.1989.]

Shipboard Scientific Party, 1989b, Site 754, chap. 8 of Broken Ridge and Ninetyeast Ridge * * * sites 752-758***: Proceedings of the Ocean Drilling Program, Initial Reports, v. 121, p. 191-236. [Also available at https://doi.org/10.2973/odp. proc.ir.121.108.1989.]

Shipboard Scientific Party, 1989c, Site 757, chap. 11 of Broken Ridge and Ninetyeast Ridge * * * sites 752-758***: Proceedings of the Ocean Drilling Program, Initial Reports, v. 121, p. 305-358. [Also available at https://doi.org/10.2973/odp. proc.ir.121.111.1989.]

Shipboard Scientific Party, 1989d, Site 758, chap. 12 of Broken Ridge and Ninetyeast Ridge * * * sites 752-758* **: Proceedings of the Ocean Drilling Program, Initial Reports, v. 121, p. 359-453. [Also available at https://doi.org/10.2973/odp. proc.ir.121.112.1989.] 
Shipboard Scientific Party, 1990a, Site 763, chap. 9 of Exmouth Plateau $* * *$ sites 759-764 * * * Proceedings of the Ocean Drilling Program, Initial Reports, v. 122, p. 289-352. [Also available at https://doi.org/10.2973/odp.proc.ir.122.109.1990.]

Shipboard Scientific Party, 1990b, Site 769, chap. 12 of Celebes and Sulu Seas * * * sites 767-771***: Proceedings of the Ocean Drilling Program, Initial Reports, v. 124, p. 299-342. [Also available at https://doi.org/10.2973/odp.proc. ir.124.112.1990.]

Shipboard Scientific Party, 1993a, Site 881, chap. 3 of North Pacific transect $* * *$ sites $881-887 * * *$ : Proceedings of the Ocean Drilling Program, Initial Reports, v. 145, p. 37-83. [Also available at https://doi.org/10.2973/odp.proc. ir.145.105.1993.]

Shipboard Scientific Party, 1993b, Site 883, chap. 5 of North Pacific transect $* * *$ sites $881-887 * * *$ : Proceedings of the Ocean Drilling Program, Initial Reports, v. 145, p. 121-208. [Also available at https://doi.org/10.2973/odp.proc. ir.145.107.1993.]

Shipboard Scientific Party, 1993c, Site 887, chap. 8 of North Pacific transect $* * *$ sites $881-887 * * *$ : Proceedings of the Ocean Drilling Program, Initial Reports, v. 145, p. 335-391. [Also available at http://doi.org/10.2973/odp.proc. ir.145.110.1993.]

Shipboard Scientific Party, 2003, Site 1236, chap. 7 of Southeast Pacific paleoceanographic transects * * * sites 1232-1242 * * *: Proceedings of the Ocean Drilling Program, Initial Reports, v. 202. [Also available at https://doi.org/10.2973/odp.proc. ir.202.107.2003.]

Siesser, W.G., 2001, Pliocene paleoclimatology at ODP site 1115, Solomon Sea (southwestern Pacific Ocean), based on calcareous nannofossils, chap. 11 of Huchon, Philippe, Taylor, Brian, and Klaus, Adam, eds., Active continental extension in the Western Woodlark Basin, Papua New Guinea $* * *$ sites 1108-1118****: Proceedings of the Ocean Drilling Program, Scientific Results, v. 180, p. 1-15. [Also available at https://doi.org/10.2973/odp.proc.sr.180.154.2001.]

Snyder, S.W., and Waters, V.J., 1985, Cenozoic planktonic foraminiferal biostratigraphy of the Goban Spur region, Deep Sea Drilling Project Leg 80, chap. 10 of Volume LXXX, Part 1 covering Leg 80 of the cruises of the drilling vessel Glomar Challenger, Brest, France, to Southampton, United Kingdom, June-July, 1981: Initial Reports of the Deep Sea Drilling Project, v. 80, p. 439-472. [Also available at https://doi.org/10.2973/dsdp.proc.80.110.1985.]

Spaak, P., 1983, Accuracy in correlation and ecological aspects of the planktonic foraminiferal zonation of the Mediterranean Pliocene: Utrecht Micropaleontological Bulletin, v. 28, 159 p. [Also available at https://dspace.library.uu.nl/ handle/1874/205886.]

Spaulding, S.A., Bloemendal, J., Hayashida, A., Hermelin, J.O.R., Kameo, K., Kroon, D., Nigrini, C.A., Sato, T., Steens, T.N.F., Takayama, T., and Troelstra, S.R., 1991, Magnetostratigraphic and biostratigraphic synthesis, Leg 117, Arabian Sea, chap. 5 of Emeis, Kay-C., Meyers, P.A., Niitsuma, Nobuaki, and Prell, W.L., eds., Oman Margin/Neogene Package * ** sites 720-731***: Proceedings of the Ocean Drilling Program, Scientific Results, v. 117, p. 127-145. [Also available at http://doi.org/10.2973/odp.proc.sr.117.186.1991.]

Stoll, Danielle, 2010, Mid-Piacenzian sea surface temperature record from ODP site 1115 in the western equatorial Pacific: Stratigraphy, v. 7, no. 1, p. 1-6. [Also available at http://www.micropress.org/micropen2/articles/1/6/96953_articles_article_ file_1675.pdf.]

Takayama, Toshiaki, and Sato, Tokiyuki, 1986, Coccolith biostratigraphy of the North Atlantic Ocean, Deep Sea Drilling Project Leg 94, chap. 13 of Volume XCIV, Part 1 covering Leg 94 of cruises of the drilling vessel Glomar Challenger, Norfolk, Virginia, to St. John's, Newfoundland, June-August 1983: Initial Reports of the Deep Sea Drilling Project, v. 94, p. 651-702. [Also available at https://doi.org/10.2973/dsdp.proc.94.113.1987.]

Tang, Cheng, 1992, Paleomagnetism of Cenozoic sediments in holes 762B and 763A, central Exmouth Plateau, northwest Australia, chap. 43 of von Rad, Ulrich, Ul Haq, Bilal, Kidd, R.B., and O'Connell, Suzanne, eds., Exmouth Plateau * * * sites 759-764* * *: Proceedings of the Ocean Drilling Program, Scientific Results, v. 122, p. 717-733. [Also available at https://doi.org/10.2973/odp.proc.sr.122.153.1992.]

Thunell, R.C., 1979, Climatic evolution of the Mediterranean Sea during the last 5.0 million years: Sedimentary Geology, v. 23, nos. 1-4, p. 67-79. [Also available at https://doi.org/10.1016/0037-0738(79)90006-X.] 
Tiedemann, R., and Franz, S.O., 1997, Deep-water circulation, chemistry, and terrigenous sediment supply in the equatorial Atlantic during the Pliocene, 3.3-2.6 Ma and 5-4.5 Ma, chap. 20 of Shackleton, N.J., Curry, W.B., Richter, Carl, and Bralower, T.J., eds., Ceara Rise * * * sites 925-929***: Proceedings of the Ocean Drilling Program, Scientific Results, v. 154, p. 299-318. [Also available at https://doi.org/10.2973/odp.proc.sr.154.120.1997.]

Tiedemann, Ralf, Sarnthein, Michael, and Shackleton, N.J., 1994, Astronomic timescale for the Pliocene Atlantic $\delta^{18} \mathrm{O}$ and dust flux records of Ocean Drilling Program site 659: Paleoceanography, v. 9, no. 4, p. 619-638. [Also available at https://doi.org/10.1029/94PA00208.]

Tiedemann, Ralf, Sturm, Arne, Steph, Silke, Lund, S.P., and Stoner, J.S., 2007, Astronomically calibrated timescales from 6 to 2.5 Ma and benthic isotope stratigraphies, sites 1236, 1237, 1239, and 1241, chap. 4 of Tiedemann, Ralf, Mix, A.C., Richter, Carl, and Ruddiman, Bill, eds., Southeast Pacific paleoceanographic transects * * * sites 1232-1242* * *: Proceedings of the Ocean Drilling Program, Scientific Results, v. 202, p. 1-69. [Also available at https://doi.org/10.2973/odp.proc. sr.202.210.2007.]

Townsend, H.A., 1985, The paleomagnetism of sediments acquired from the Goban Spur on Deep Sea Drilling Project Leg 80, chap. 7 of Volume LXXX, Part 1 covering Leg 80 of the cruises of the drilling vessel Glomar Challenger, Brest, France, to Southampton, United Kingdom, June-July, 1981: Initial Reports of the Deep Sea Drilling Project, v. 80, p. 389-414. [Also available at https://doi.org/10.2973/dsdp.proc.80.107.1985.]

Verhoeven, Koen, Louwye, Stephen, Eiríksson, Jón, and De Schepper, Stijn, 2011, A new age model for the PliocenePleistocene Tjörnes section of Iceland - Its implication for the timing of North Atlantic-Pacific palaeoceanographic pathways: Palaeogeography, Palaeoclimatology, Palaeoecology, v. 309, nos. 1-2, p. 33-52. [Also available at https://doi.org/10.1016/ j.palaeo.2011.04.001.]

Wade, B.S., Pearson, P.N., Berggren, W.A., and Pälike, Heiko, 2011, Review and revision of Cenozoic tropical planktonic foraminiferal biostratigraphy and calibration to the geomagnetic polarity and astronomical time scale: Earth Science Reviews, v. 104, nos. 1-3, p. 111-142. [Also available at https://doi.org/10.1016/j.earscirev.2010.09.003.]

Waelbroeck, C., Labeyrie, L., Duplessy, J.-C., Guiot, J., Labracherie, M., Leclaire, H., and Duprat, J., 1998, Improving past sea surface temperature estimates based on planktonic fossil faunas: Paleoceanography, v. 13, no. 3, p. 272-283. [Also available at https://doi.org/10.1029/98PA00071.]

Wara, M.W., and Ravelo, A.C., 2006, Data report $-\mathrm{Mg} / \mathrm{Ca}, \mathrm{Sr} / \mathrm{Ca}, \mathrm{Mn} / \mathrm{Ca}$, and oxygen and carbon isotope records of PliocenePleistocene foraminifers from ODP Leg 202 site 1237, chap. 11 of Tiedemann, Ralf, Mix, A.C., Richter, Carl, and Ruddiman, Bill, eds., Southeast Pacific paleoceanographic transects * * * sites 1232-1242***: Proceedings of the Ocean Drilling Program, Scientific Results, v. 202, p. 1-19. [Also available at https://doi.org/10.2973/odp.proc.sr.202.206.2006.]

Wara, M.W., Ravelo, A.C., and Delaney, M.L., 2005, Permanent El Niño-like conditions during the Pliocene warm period: Science, v. 309, no. 5735, p. 758-761. [Also available at https://doi.org/10.1126/science.1112596.]

Weaver, P.P.E., 1986, Late Miocene to recent planktonic foraminifers from the North Atlantic—Deep Sea Drilling Project Leg 94, chap. 14 of Volume XCIV, Part 1 covering Leg 94 of the cruises of the drilling vessel Glomar Challenger, Norfolk, Virginia, to St. John's, Newfoundland, June-August 1983: Initial Reports of the Deep Sea Drilling Project, v. 94, p. $703-727$. [Also available at https://doi.org/10.2973/dsdp.proc.94.114.1987.]

Weaver, P.P.E., Backman, J., Baldauf, J.G., Bloemendal, J., Manivit, H., Miller, K.G., Pokras, E.M., Raymo, M.E., Tauxe, L., Valet, J.-P., Chepstow-Lusty, A., and Olafsson, G., 1989, Biostratigraphic synthesis-Leg 108, eastern equatorial Atlantic, chap. 28 of Baldauf, Jack, Heath, G.R., Ruddiman, W.F., and Sarnthein, Michael, eds., Eastern tropical Atlantic * * * sites 657-668***: Proceedings of the Ocean Drilling Program, Scientific Results, v. 108, p. 455-462. [Also available at https://doi.org/10.2973/odp.proc.sr.108.171.1989.]

Weaver, P.P.E., and Clement, B.M., 1986, Magnetobiostratigraphy of planktonic foraminiferal datums—Deep Sea Drilling Project Leg 94, North Atlantic, chap. 20 of Volume XCIV, Part 1 covering Leg 94 of the cruises of the drilling vessel Glomar Challenger, Norfolk, Virginia, to St. John's, Newfoundland, June-August 1983: Initial Reports of the Deep Sea Drilling Project, v. 94, p. 815-829. [Also available at https://doi.org/10.2973/dsdp.proc.94.120.1987.]

Webb, P.-N., and Harwood, D.M., 1991, Late Cenozoic glacial history of the Ross Embayment, Antarctica: Quaternary Science Reviews, v. 10, nos. 2-3, p. 215-223. [Also available at https://doi.org/10.1016/0277-3791(91)90020-U.] 
Westall, F., and Fenner, J., 1990, Polar front fluctuations and the upper Gauss to Brunhes paleoceanographic record in the southeast Atlantic Ocean, in Bleil, Ulrich, and Thiede, Jörn, eds., Geological history of the polar oceans - Arctic versus Antarctic: Dordrecht, Netherlands, Kluwer Academic Publishers, p. 761-782. [NATO ASI (North Atlantic Treaty Organization, Advanced Science Institute) Series C, v. 308. Also available at https://doi.org/10.1007/978-94-009-2029-3.]

Wiggs, L.B., and Dowsett, H.J., 1992, Pliocene planktic foraminifer census data from Deep Sea Drilling Project hole 396 and Ocean Drilling Program hole 672: U.S. Geological Survey Open-File Report 92-414, 5 p. [Also available at https://doi.org/10.3133/ofr92414.]

Williams, Mark, Haywood, A.M., Harper, E.M., Johnson, A.L.A., Knowles, Tanya, Leng, M.J., Lunt, D.J., Okamura, Beth, Taylor, P.D., and Zalasiewicz, Jan, 2009, Pliocene climate and seasonality in North Atlantic shelf seas: Philosophical Transactions of the Royal Society A, v. 367, no. 1886, p. 85-108. [Also available at https://doi.org/10.1098/rsta.2008.0224.]

Wilson, D.S., 1984, Paleomagnetic results from Deep Sea Drilling Project Leg 78A, chap. 31 of Volume LXXVIIIA covering Leg 78A of the cruises of the drilling vessel Glomar Challenger, San Juan, Puerto Rico, to San Juan, Puerto Rico, February-March, 1981: Initial Reports of the Deep Sea Drilling Project, v. 78, p. 583-591. [Also available at https://doi.org/ 10.2973/dsdp.proc.78a.131.1984.]

Wood, A.M., Whatley, R.C., Cronin, T.M., and Holtz, T., 1993, Pliocene palaeotemperature reconstruction for the southern North Sea based on ostracoda: Quaternary Science Reviews, v. 12, no. 9, p. 747-767. [Also available at https://doi.org/10.1016/0277-3791(93)90015-E.]

Wright, J.D., and Kroon, Dick, 2000, Planktonic foraminiferal biostratigraphy of Leg 166, chap. 1 of Swart, P.K., Eberli, G.P., Malone, M.J., and Sarg, J.F., eds., Bahamas transect $* * *$ sites 1003-1009***: Proceedings of the Ocean Drilling Program, Scientific Results, v. 166, p. 3-12. [Also available at https://doi.org/10.2973/odp.proc.sr.166.101.2000.]

Zimmerman, H.B., Shackleton, N.J., Backman, J., Kent, D.V., Baldauf, J.G., Kaltenback, A.J., and Morton, A.C., 1985, History of Plio-Pleistocene climate in the northeastern Atlantic, Deep Sea Drilling Project hole 552A, chap. 37 of Volume LXXXI covering Leg 81 of the cruises of the drilling vessel Glomar Challenger, Southampton, United Kingdom, to Ponta Delgada, Azores Islands, July-September, 1981: Initial Reports of the Deep Sea Drilling Project, v. 81, p. 861-875. [Also available at https://doi.org/10.2973/dsdp.proc.81.137.1984.] 


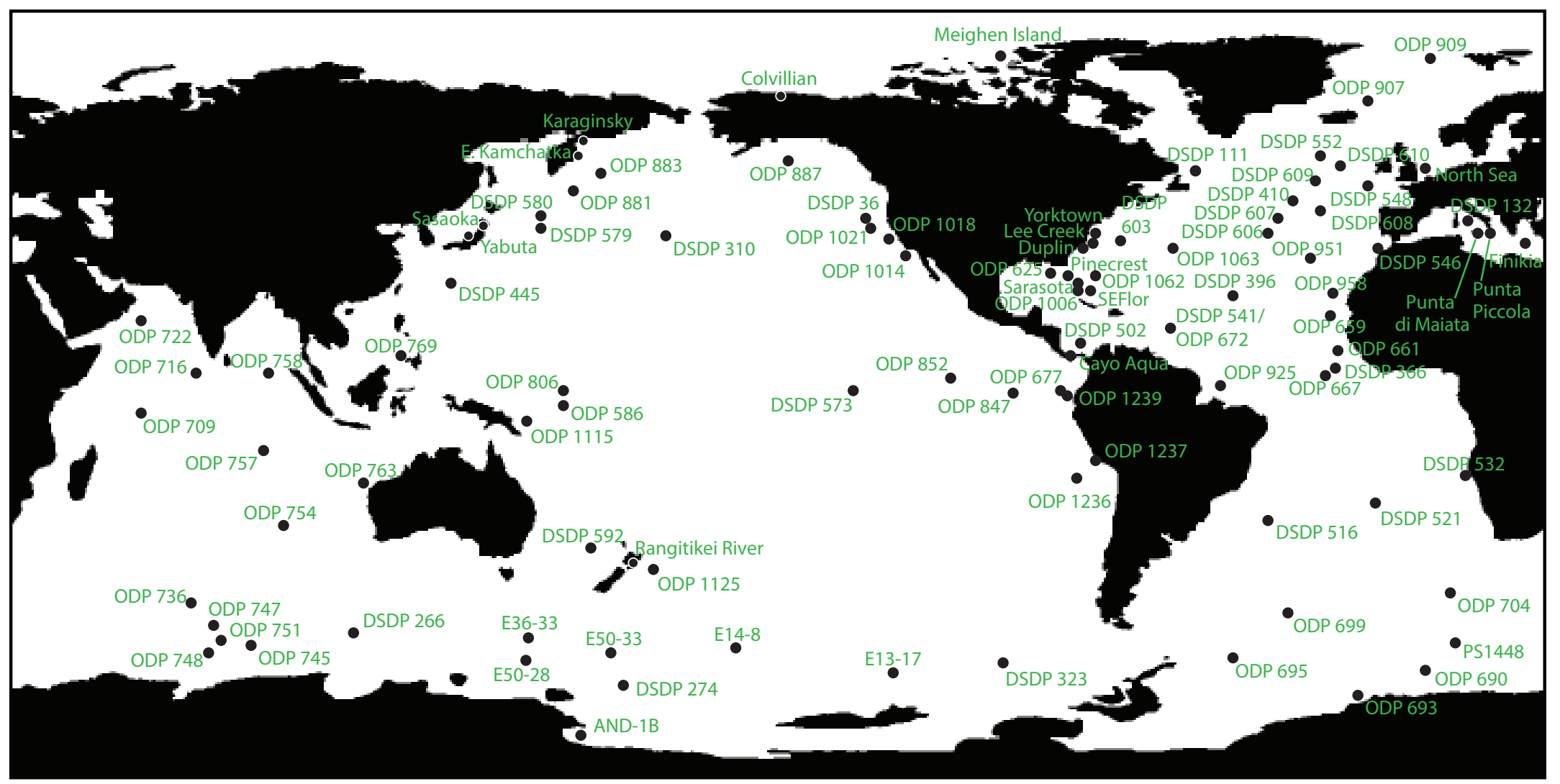

Figure 1A. Map showing locations of sites in the PRISM verification dataset, which are discussed in this report and listed in table 1. 

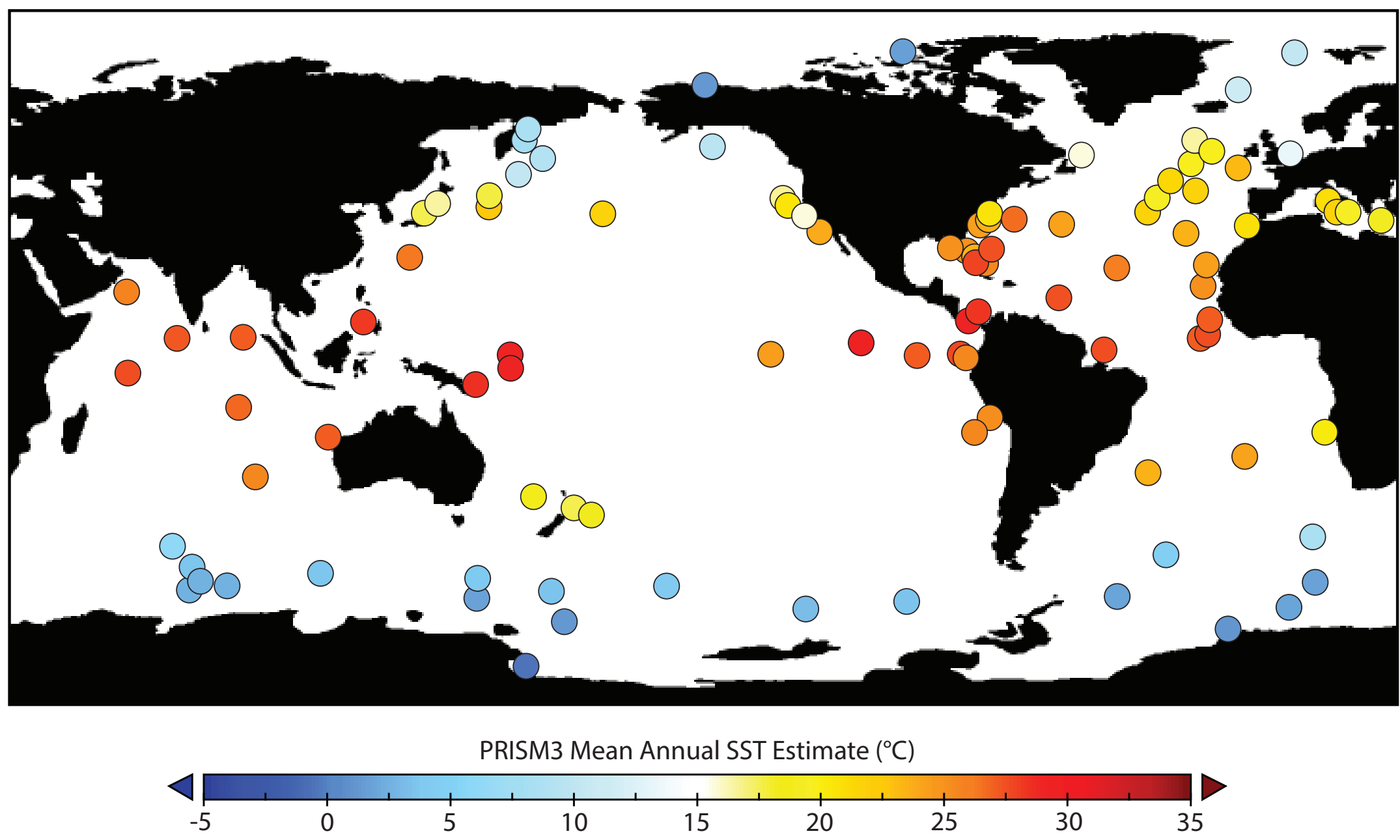

Figure 1B. Map showing sea surface temperature estimates for the PRISM3 interval at sites in the PRISM verification dataset, which are discussed in this report and listed in table 1. 


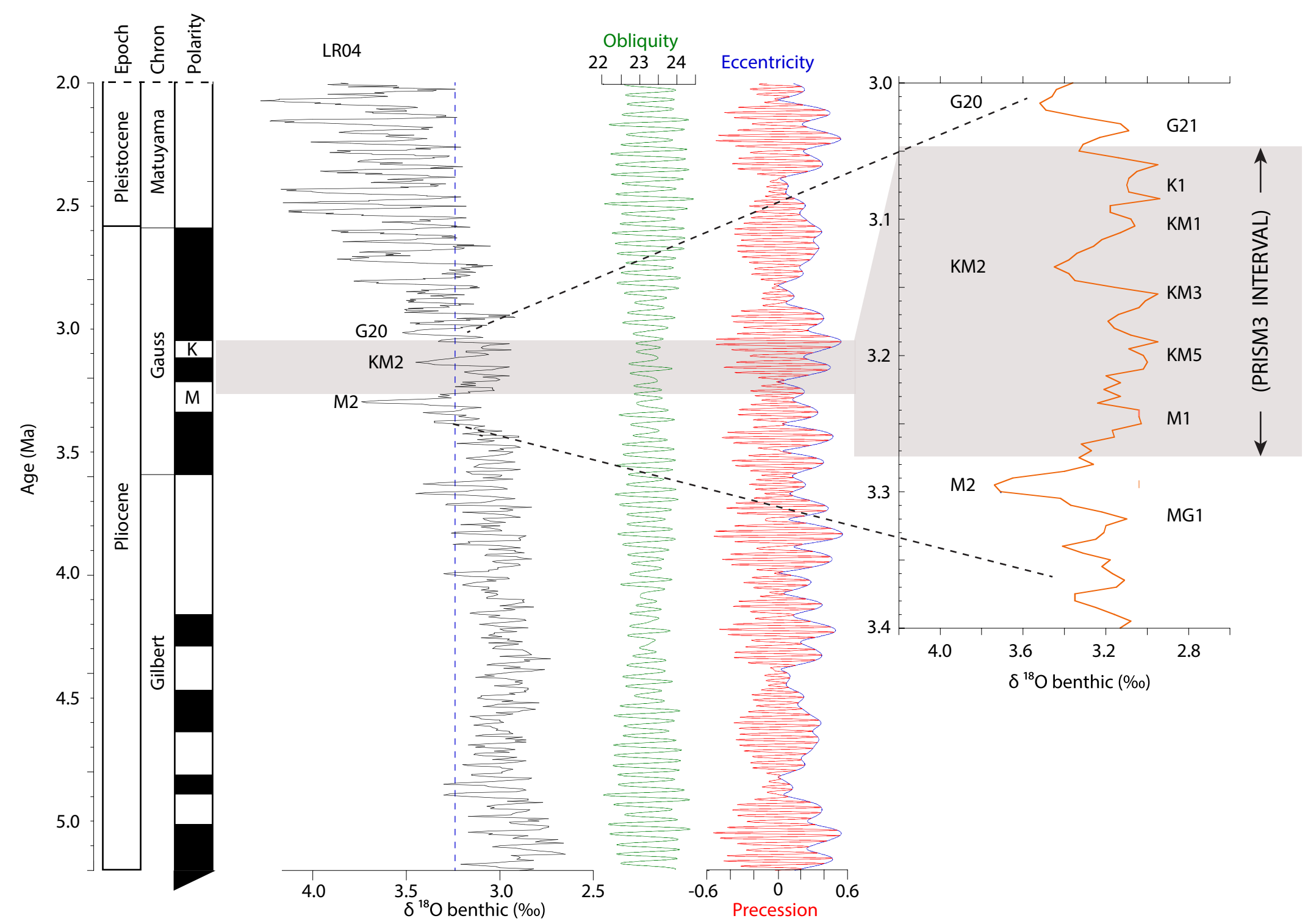

Figure 2. Diagram showing the chronology of the PRISM interval. LR04 benthic oxygen isotope data are plotted from Lisiecki and Raymo (2005) and include locations of main isotope stages of this period. Kaena (K) and Mammoth (M) reversed polarities within the Gauss Normal Polarity Chron are shown. 


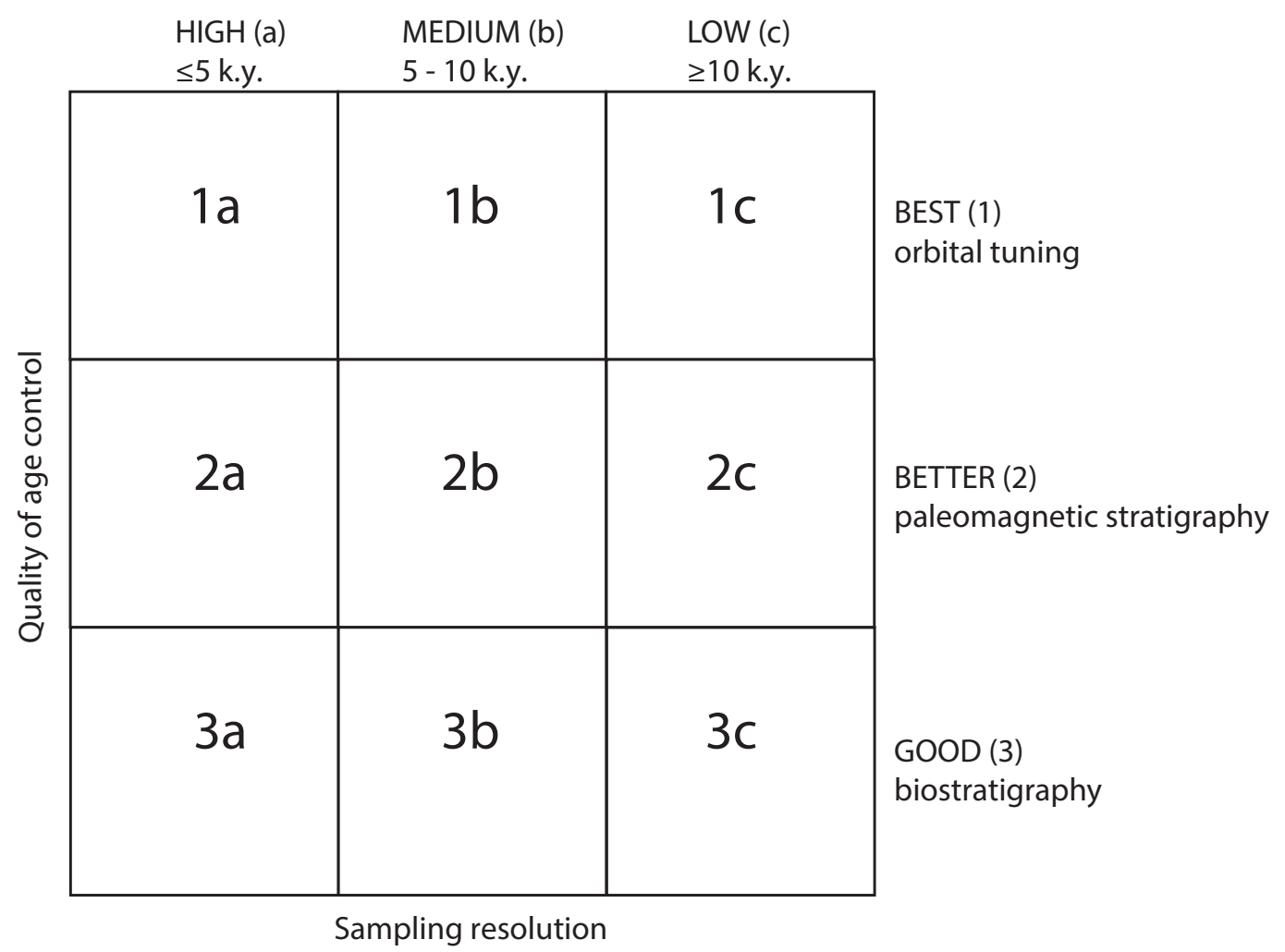

Figure 3. Stratigraphic fidelity rubric showing rating by quality of age control $(1,2$, or 3$)$ and sampling resolution ( $a, b$, or $c)$, shown as intervals in thousand years (k.y.), to scale the utility of individual records in model experiments requiring specific criteria (from Dowsett, Robinson, and Foley, 2017).

Figure 4. (facing page) Scoring rubric for estimates of confidence in the sea surface temperature estimates for the mid-Piacenzian interval (modified from Dowsett and others, 2012). The total confidence is the sum of the scores for the individual confidence attributes $\left(b_{1}-b_{5}\right)$ for a given estimate and is broken into four categories based on value: $\operatorname{low}(5-8)$, medium (9-12), high (13-15), and very high (16-18). Gray shaded boxes indicate that this score is not applicable for the given confidence attribute. Small shaded circles relating to proxy performance denote scores equal to or less than zero. 


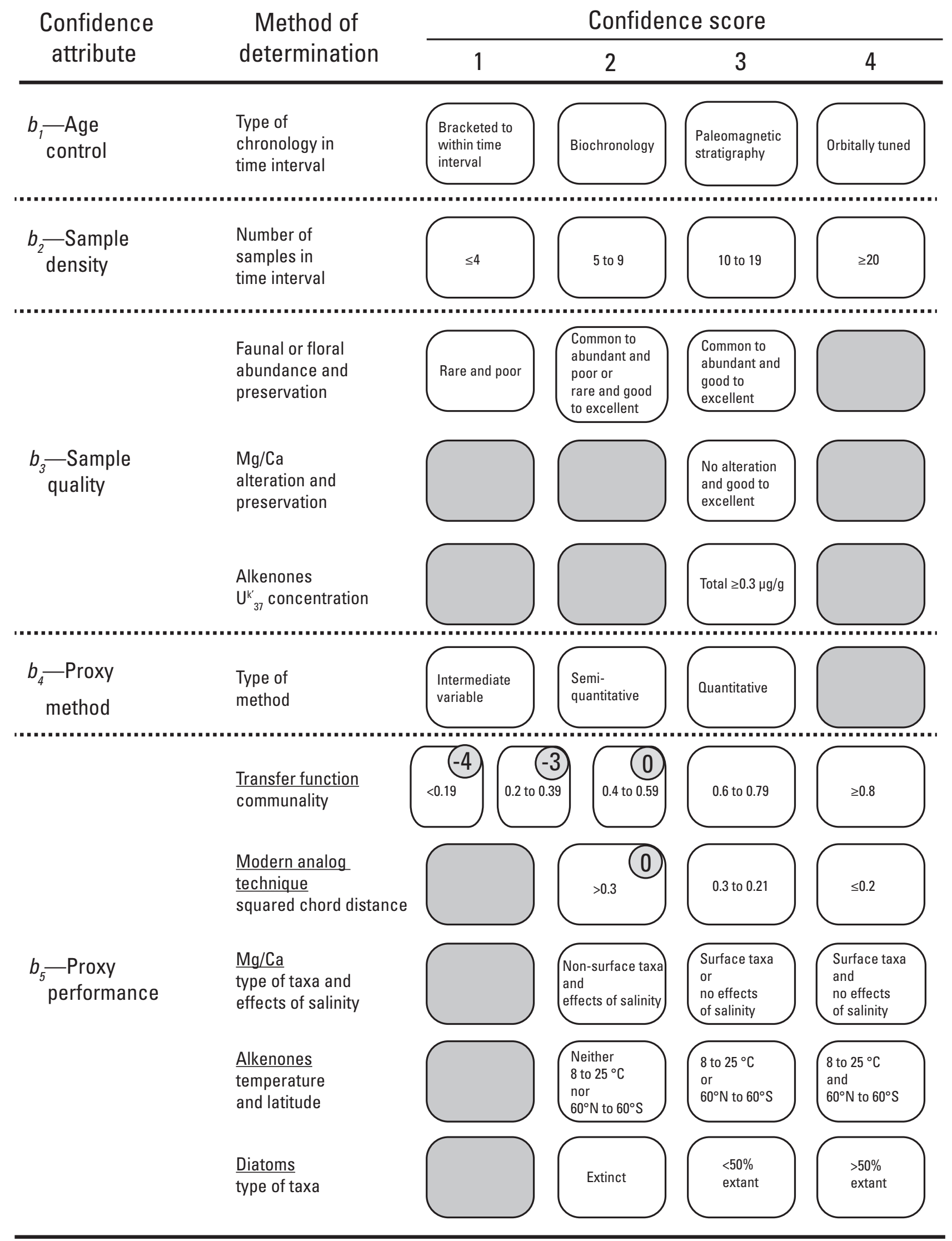


Table 1. Mean annual sea surface temperature estimates for the mid-Piacenzian PRISM interval, measures of the confidence of the estimates, and stratigraphic fidelity for the sites in the PRISM verification dataset.

[New or revised data are in italics. PRISM, Pliocene Research, Interpretation and Synoptic Mapping; SST, sea surface temperature; ${ }^{\circ} \mathrm{C}$, degree Celsius; $b_{1}$, age control; $b_{2}$, sample density; $b_{3}$, sample quality; $b_{4}$, proxy method; $b_{5}$, proxy performance; $\lambda$, confidence score; DSDP, Deep Sea Drilling Project; ODP, Ocean Drilling Program; $\mathrm{Mg} / \mathrm{Ca}$, magnesium to calcium ratio; $\mathrm{n} / \mathrm{a}$, cannot be rated using the stratigraphic fidelity rubric]

\begin{tabular}{|c|c|c|c|c|c|c|c|c|c|c|}
\hline \multirow{2}{*}{ Site } & \multirow{2}{*}{$\begin{array}{c}\text { Mean } \\
\text { annual } \\
\text { SST }\left({ }^{\circ} \mathrm{C}\right)\end{array}$} & \multirow{2}{*}{ Proxy } & \multicolumn{5}{|c|}{ Confidence attribute score } & \multicolumn{2}{|c|}{ Total confidence } & \multirow{2}{*}{$\begin{array}{c}\text { Stratigraphic } \\
\text { fidelity }\end{array}$} \\
\hline & & & $b_{1}$ & $b_{2}$ & $b_{3}$ & $\boldsymbol{b}_{4}$ & $b_{5}$ & $\lambda$ & Category & \\
\hline \multicolumn{11}{|c|}{ North Atlantic Ocean } \\
\hline$D S D P 111$ & 15.2 & Foraminifera & 2 & 2 & 3 & 3 & 4 & 14 & high & $3 c$ \\
\hline DSDP 366 & 27.5 & Foraminifera & 2 & 3 & 3 & 3 & 4 & 15 & high & $3 c$ \\
\hline DSDP 396 & 26.1 & Foraminifera & 2 & 3 & 3 & 3 & 4 & 15 & high & $3 c$ \\
\hline DSDP 410 & 20.6 & Foraminifera & 2 & 3 & 3 & 3 & 4 & 15 & high & $3 c$ \\
\hline DSDP 502 & 27.9 & Foraminifera & 3 & 4 & 3 & 3 & 3 & 16 & very high & $2 c$ \\
\hline DSDP $541^{1}$ & 27.2 & Foraminifera & 2 & 3 & 3 & 3 & 3 & 14 & high & $3 c$ \\
\hline ODP $672^{1}$ & 27.2 & Foraminifera & 2 & 3 & 3 & 3 & 3 & 14 & high & $3 c$ \\
\hline DSDP 546 & 21.6 & Foraminifera & 3 & 2 & 3 & 3 & 3 & 14 & high & $2 c$ \\
\hline DSDP 548 & 23.0 & Foraminifera & 3 & 4 & 3 & 3 & 3 & 16 & very high & $2 c$ \\
\hline DSDP 552 & 16.7 & $\begin{array}{l}\text { Foraminifera } \\
\mathrm{Mg} / \mathrm{Ca} \\
\text { Alkenones }\end{array}$ & $\begin{array}{l}3 \\
3 \\
3\end{array}$ & $\begin{array}{l}4 \\
4 \\
3\end{array}$ & $\begin{array}{l}3 \\
3 \\
3\end{array}$ & $\begin{array}{l}3 \\
3 \\
3\end{array}$ & $\begin{array}{l}4 \\
3 \\
4\end{array}$ & $\begin{array}{l}17 \\
16 \\
16\end{array}$ & very high & $2 c$ \\
\hline DSDP 603 & 26.4 & Foraminifera & 3 & 3 & 2 & 3 & 3 & 14 & high & $2 c$ \\
\hline DSDP 606 & 21.6 & $\begin{array}{l}\text { Foraminifera } \\
\mathrm{Mg} / \mathrm{Ca} \\
\text { Alkenones }\end{array}$ & $\begin{array}{l}3 \\
3 \\
3\end{array}$ & $\begin{array}{l}4 \\
4 \\
4\end{array}$ & $\begin{array}{l}3 \\
3 \\
3\end{array}$ & $\begin{array}{l}3 \\
3 \\
3\end{array}$ & $\begin{array}{l}3 \\
4 \\
4\end{array}$ & $\begin{array}{l}16 \\
17 \\
17\end{array}$ & very high & $2 c$ \\
\hline DSDP 607 & 18.9 & $\begin{array}{l}\text { Foraminifera } \\
\mathrm{Mg} / \mathrm{Ca} \\
\text { Alkenones }\end{array}$ & $\begin{array}{l}4 \\
4 \\
4\end{array}$ & $\begin{array}{l}3 \\
3 \\
3\end{array}$ & $\begin{array}{l}3 \\
3 \\
3\end{array}$ & $\begin{array}{l}3 \\
3 \\
3\end{array}$ & $\begin{array}{l}4 \\
3 \\
3\end{array}$ & $\begin{array}{l}17 \\
16 \\
17\end{array}$ & very high & $1 c$ \\
\hline DSDP 608 & 21.7 & Foraminifera & 3 & 4 & 3 & 3 & 3 & 16 & very high & $2 b$ \\
\hline DSDP 609 & 19.4 & $\begin{array}{l}\text { Foraminifera } \\
\mathrm{Mg} / \mathrm{Ca} \\
\text { Alkenones }\end{array}$ & $\begin{array}{l}3 \\
3 \\
3\end{array}$ & $\begin{array}{l}4 \\
4 \\
4\end{array}$ & $\begin{array}{l}3 \\
3 \\
3\end{array}$ & $\begin{array}{l}3 \\
3 \\
3\end{array}$ & $\begin{array}{l}3 \\
3 \\
4\end{array}$ & $\begin{array}{l}16 \\
16 \\
17\end{array}$ & very high & $2 c$ \\
\hline DSDP 610 & 19.3 & Foraminifera & 3 & 4 & 3 & 3 & 4 & 17 & very high & $2 c$ \\
\hline ODP 659 & 25.0 & Foraminifera & 4 & 3 & 3 & 3 & 3 & 16 & very high & $1 c$ \\
\hline ODP 661 & 26.9 & Foraminifera & 3 & 4 & 3 & 3 & 4 & 17 & very high & $2 b$ \\
\hline ODP 667 & 27.0 & Foraminifera & 2 & 3 & 3 & 3 & 4 & 15 & high & $3 c$ \\
\hline$O D P 925$ & 27.4 & $\begin{array}{l}\text { Foraminifera } \\
\text { Alkenones }\end{array}$ & $\begin{array}{l}4 \\
4\end{array}$ & $\begin{array}{l}4 \\
4\end{array}$ & $\begin{array}{l}3 \\
3\end{array}$ & $\begin{array}{l}3 \\
3\end{array}$ & $\begin{array}{l}4 \\
3\end{array}$ & $\begin{array}{l}18 \\
17\end{array}$ & very high & $1 c$ \\
\hline ODP 951 & 23.5 & $\begin{array}{l}\text { Foraminifera } \\
\mathrm{Mg} / \mathrm{Ca} \\
\text { Alkenones }\end{array}$ & $\begin{array}{l}3 \\
3 \\
3\end{array}$ & $\begin{array}{l}4 \\
4 \\
4\end{array}$ & $\begin{array}{l}3 \\
3 \\
3\end{array}$ & $\begin{array}{l}3 \\
3 \\
3\end{array}$ & $\begin{array}{l}3 \\
4 \\
4\end{array}$ & $\begin{array}{l}16 \\
17 \\
17\end{array}$ & very high & $2 c$ \\
\hline ODP 958 & 24.0 & $\begin{array}{l}\text { Foraminifera } \\
\mathrm{Mg} / \mathrm{Ca} \\
\text { Alkenones }\end{array}$ & $\begin{array}{l}3 \\
3 \\
3\end{array}$ & $\begin{array}{l}4 \\
4 \\
4\end{array}$ & $\begin{array}{l}3 \\
3 \\
3\end{array}$ & $\begin{array}{l}3 \\
3 \\
3\end{array}$ & $\begin{array}{l}0 \\
4 \\
4\end{array}$ & $\begin{array}{l}13 \\
17 \\
17\end{array}$ & very high & $2 b$ \\
\hline ODP 1006 & 27.9 & $\begin{array}{l}\text { Foraminifera } \\
\mathrm{Mg} / \mathrm{Ca} \\
\text { Alkenones }\end{array}$ & $\begin{array}{l}2 \\
2 \\
2\end{array}$ & $\begin{array}{l}4 \\
4 \\
2\end{array}$ & $\begin{array}{l}3 \\
3 \\
3\end{array}$ & $\begin{array}{l}3 \\
3 \\
3\end{array}$ & $\begin{array}{l}0 \\
3 \\
3\end{array}$ & $\begin{array}{l}12 \\
15 \\
13\end{array}$ & high & $3 b$ \\
\hline ODP 1062 & 27.2 & $\begin{array}{l}\text { Foraminifera } \\
\mathrm{Mg} / \mathrm{Ca} \\
\text { Alkenones }\end{array}$ & $\begin{array}{l}3 \\
3 \\
3\end{array}$ & $\begin{array}{l}4 \\
4 \\
4\end{array}$ & $\begin{array}{l}3 \\
3 \\
3\end{array}$ & $\begin{array}{l}3 \\
3 \\
3\end{array}$ & $\begin{array}{l}4 \\
3 \\
3\end{array}$ & $\begin{array}{l}17 \\
16 \\
16\end{array}$ & very high & $2 b$ \\
\hline
\end{tabular}


Table 1. Mean annual sea surface temperature estimates for the mid-Piacenzian PRISM interval, measures of the confidence of the estimates, and stratigraphic fidelity for the sites in the PRISM verification dataset.-Continued

[New or revised data are in italics. PRISM, Pliocene Research, Interpretation and Synoptic Mapping; SST, sea surface temperature; ${ }^{\circ} \mathrm{C}$, degree Celsius; $b_{1}$, age control; $b_{2}$, sample density; $b_{3}$, sample quality; $b_{4}$, proxy method; $b_{5}$, proxy performance; $\lambda$, confidence score; DSDP, Deep Sea Drilling Project; ODP, Ocean Drilling Program; $\mathrm{Mg} / \mathrm{Ca}$, magnesium to calcium ratio; $\mathrm{n} / \mathrm{a}$, cannot be rated using the stratigraphic fidelity rubric]

\begin{tabular}{|c|c|c|c|c|c|c|c|c|c|c|}
\hline \multirow{2}{*}{ Site } & \multirow{2}{*}{$\begin{array}{c}\text { Mean } \\
\text { annual } \\
\text { SST }\left({ }^{\circ} \mathrm{C}\right)\end{array}$} & \multirow{2}{*}{ Proxy } & \multicolumn{5}{|c|}{ Confidence attribute score } & \multicolumn{2}{|c|}{ Total confidence } & \multirow{2}{*}{$\begin{array}{c}\text { Stratigraphic } \\
\text { fidelity }\end{array}$} \\
\hline & & & $b_{1}$ & $b_{2}$ & $b_{3}$ & $b_{4}$ & $b_{5}$ & $\lambda$ & Category & \\
\hline \multicolumn{11}{|c|}{ North Atlantic Ocean-Continued } \\
\hline ODP 1063 & 23.8 & $\begin{array}{l}\text { Foraminifera } \\
\text { Alkenones }\end{array}$ & $\begin{array}{l}3 \\
3\end{array}$ & $\begin{array}{l}4 \\
4\end{array}$ & $\begin{array}{l}3 \\
3\end{array}$ & $\begin{array}{l}3 \\
3\end{array}$ & $\begin{array}{l}4 \\
4\end{array}$ & $\begin{array}{l}17 \\
17\end{array}$ & very high & $2 c$ \\
\hline Cayo Aqua & 28.8 & Ostracods & 3 & 3 & 3 & 3 & 0 & 12 & medium & $2 c$ \\
\hline SEFlor & 25.7 & Ostracods & 2 & 1 & 3 & 3 & 0 & 9 & medium & $3 c$ \\
\hline Pinecrest Beds & 24.9 & Ostracods & 2 & 1 & 3 & 3 & 3 & 12 & medium & $3 c$ \\
\hline Sarasota & 23.4 & Ostracods & 3 & 2 & 3 & 3 & 3 & 14 & high & $2 c$ \\
\hline Duplin & 23.9 & Ostracods & 2 & 2 & 3 & 3 & 3 & 13 & high & $3 c$ \\
\hline Lee Creek & 23.5 & Ostracods & 3 & 2 & 3 & 3 & 3 & 14 & high & $2 c$ \\
\hline Yorktown & 21.5 & $\begin{array}{l}\text { Ostracods } \\
\text { Foraminifera }\end{array}$ & $\begin{array}{l}2 \\
1\end{array}$ & $\begin{array}{l}2 \\
4\end{array}$ & $\begin{array}{l}3 \\
3\end{array}$ & $\begin{array}{l}3 \\
3\end{array}$ & $\begin{array}{l}3 \\
4\end{array}$ & $\begin{array}{l}13 \\
15\end{array}$ & high & $3 c$ \\
\hline \multicolumn{11}{|c|}{ South Atlantic Ocean, Gulf of Mexico, Mediterranean Sea } \\
\hline DSDP 516 & 23.3 & Foraminifera & 3 & 4 & 3 & 3 & 0 & 13 & high & $2 c$ \\
\hline DSDP 521 & 24.1 & Foraminifera & 3 & 3 & 3 & 3 & 0 & 12 & medium & $2 c$ \\
\hline DSDP 532 & 20.1 & Foraminifera & 3 & 2 & 2 & 2 & 0 & 9 & medium & $2 c$ \\
\hline ODP 704 & 8.4 & Foraminifera & 3 & 4 & 3 & 3 & 4 & 17 & very high & $2 c$ \\
\hline ODP 625 & 25.0 & Alkenones & 2 & 4 & 3 & 3 & 3 & 15 & high & $3 c$ \\
\hline DSDP 132 & 21.0 & Foraminifera & 2 & 2 & 3 & 3 & 3 & 13 & high & $3 c$ \\
\hline Finikia & 18.0 & Foraminifera & 2 & 4 & 2 & 3 & 3 & 14 & high & $3 b$ \\
\hline Punta di Maiata & 19.4 & Foraminifera & 2 & 4 & 2 & 3 & 3 & 14 & high & $3 b$ \\
\hline Punta Piccola & 21.4 & Foraminifera & 2 & 4 & 2 & 3 & 3 & 14 & high & $3 b$ \\
\hline \multicolumn{11}{|c|}{ Pacific Ocean } \\
\hline DSDP 36 & 16.8 & Foraminifera & 3 & 3 & 2 & 2 & 0 & 10 & medium & $2 c$ \\
\hline DSDP 310 & 21.6 & Foraminifera & 2 & 3 & 3 & 3 & 0 & 11 & medium & $3 c$ \\
\hline DSDP 445 & 26.2 & $\begin{array}{l}\text { Foraminifera } \\
\mathrm{Mg} / \mathrm{Ca}\end{array}$ & $\begin{array}{l}2 \\
2\end{array}$ & $\begin{array}{l}3 \\
3\end{array}$ & $\begin{array}{l}2 \\
2\end{array}$ & $\begin{array}{l}3 \\
3\end{array}$ & $\begin{array}{l}3 \\
4\end{array}$ & $\begin{array}{l}13 \\
14\end{array}$ & high & $3 c$ \\
\hline DSDP 573 & 24.7 & Radiolaria & 3 & 3 & 2 & 3 & 3 & 14 & high & $2 c$ \\
\hline DSDP 579 & 22.6 & Diatoms & 3 & 3 & 3 & 3 & 4 & 16 & very high & $2 c$ \\
\hline DSDP 580 & 17.7 & Diatoms & 3 & 4 & 3 & 3 & 4 & 17 & very high & $2 c$ \\
\hline DSDP 586 & 29.1 & Foraminifera & 2 & 3 & 3 & 1 & 0 & 9 & medium & $3 c$ \\
\hline DSDP 592 & 19.7 & Foraminifera & 3 & 4 & 3 & 3 & 3 & 16 & very high & $2 c$ \\
\hline ODP 677A & 27.8 & $\begin{array}{l}\text { Foraminifera } \\
\text { Alkenones }\end{array}$ & $\begin{array}{l}2 \\
2\end{array}$ & $\begin{array}{l}3 \\
4\end{array}$ & $\begin{array}{l}3 \\
3\end{array}$ & $\begin{array}{l}3 \\
3\end{array}$ & $\begin{array}{l}3 \\
3\end{array}$ & $\begin{array}{l}14 \\
15\end{array}$ & high & $3 c$ \\
\hline ODP 769B & 28.1 & Foraminifera & 3 & 2 & 1 & 3 & 3 & 12 & medium & $2 c$ \\
\hline ODP 806 & 29.1 & $\begin{array}{l}\text { Foraminifera } \\
\mathrm{Mg} / \mathrm{Ca}\end{array}$ & $\begin{array}{l}4 \\
4\end{array}$ & $\begin{array}{l}4 \\
3\end{array}$ & $\begin{array}{l}3 \\
3\end{array}$ & $\begin{array}{l}3 \\
3\end{array}$ & $\begin{array}{l}4 \\
4\end{array}$ & $\begin{array}{l}18 \\
17\end{array}$ & very high & $1 a$ \\
\hline ODP 847 & 27.1 & $\begin{array}{l}\text { Foraminifera } \\
\mathrm{Mg} / \mathrm{Ca} \\
\text { Alkenones }\end{array}$ & $\begin{array}{l}4 \\
4 \\
4\end{array}$ & $\begin{array}{l}4 \\
3 \\
2\end{array}$ & $\begin{array}{l}2 \\
3 \\
3\end{array}$ & $\begin{array}{l}3 \\
3 \\
3\end{array}$ & $\begin{array}{l}4 \\
4 \\
3\end{array}$ & $\begin{array}{l}17 \\
17 \\
15\end{array}$ & very high & $1 c$ \\
\hline ODP 852 & 29.4 & Foraminifera & 4 & 3 & 2 & 3 & 4 & 16 & very high & $1 c$ \\
\hline
\end{tabular}


Table 1. Mean annual sea surface temperature estimates for the mid-Piacenzian PRISM interval, measures of the confidence of the estimates, and stratigraphic fidelity for the sites in the PRISM verification dataset.-Continued

[New or revised data are in italics. PRISM, Pliocene Research, Interpretation and Synoptic Mapping; SST, sea surface temperature; ${ }^{\circ} \mathrm{C}$, degree Celsius; $b_{1}$, age control; $b_{2}$, sample density; $b_{3}$, sample quality; $b_{4}$, proxy method; $b_{5}$, proxy performance; $\lambda$, confidence score; DSDP, Deep Sea Drilling Project; ODP, Ocean Drilling Program; $\mathrm{Mg} / \mathrm{Ca}$, magnesium to calcium ratio; $\mathrm{n} / \mathrm{a}$, cannot be rated using the stratigraphic fidelity rubric]

\begin{tabular}{|c|c|c|c|c|c|c|c|c|c|c|}
\hline \multirow{2}{*}{ Site } & \multirow{2}{*}{$\begin{array}{l}\text { Mean } \\
\text { annual } \\
\text { SST }\left({ }^{\circ} \mathrm{C}\right)\end{array}$} & \multirow{2}{*}{ Proxy } & \multicolumn{5}{|c|}{ Confidence attribute score } & \multicolumn{2}{|c|}{ Total confidence } & \multirow{2}{*}{$\begin{array}{c}\text { Stratigraphic } \\
\text { fidelity }\end{array}$} \\
\hline & & & $b_{1}$ & $b_{2}$ & $b_{3}$ & $b_{4}$ & $b_{5}$ & $\lambda$ & Category & \\
\hline \multicolumn{11}{|c|}{ Pacific Ocean-Continued } \\
\hline ODP 881 & 10.1 & Diatoms & 3 & 4 & 3 & 3 & 4 & 17 & very high & $2 c$ \\
\hline ODP 883 & 9.1 & $\begin{array}{l}\text { Diatoms } \\
\text { Foraminifera } \\
\text { Alkenones }\end{array}$ & $\begin{array}{l}3 \\
3 \\
3\end{array}$ & $\begin{array}{l}4 \\
4 \\
3\end{array}$ & $\begin{array}{l}3 \\
2 \\
3\end{array}$ & $\begin{array}{l}3 \\
2 \\
3\end{array}$ & $\begin{array}{l}4 \\
0 \\
4\end{array}$ & $\begin{array}{l}17 \\
11 \\
16\end{array}$ & high & $2 a$ \\
\hline ODP 887 & 9.7 & $\begin{array}{l}\text { Foraminifera } \\
\text { Alkenones }\end{array}$ & $\begin{array}{l}3 \\
3\end{array}$ & $\begin{array}{l}4 \\
3\end{array}$ & $\begin{array}{l}3 \\
3\end{array}$ & $\begin{array}{l}2 \\
3\end{array}$ & $\begin{array}{l}0 \\
3\end{array}$ & $\begin{array}{l}12 \\
15\end{array}$ & high & $2 c$ \\
\hline ODP 1014 & 23.8 & Alkenones & 4 & 3 & 3 & 3 & 4 & 17 & very high & $1 c$ \\
\hline$O D P 1018$ & 15.3 & Alkenones & 2 & 4 & 3 & 3 & 4 & 16 & very high & $3 c$ \\
\hline ODP 1021 & 20.3 & Foraminifera & 3 & 3 & 2 & 3 & 3 & 14 & high & $2 a$ \\
\hline ODP 1115 & 28.3 & $\begin{array}{l}\text { Foraminifera } \\
\text { Alkenones }\end{array}$ & $\begin{array}{l}3 \\
3\end{array}$ & $\begin{array}{l}4 \\
4\end{array}$ & $\begin{array}{l}3 \\
3\end{array}$ & $\begin{array}{l}3 \\
3\end{array}$ & $\begin{array}{l}4 \\
3\end{array}$ & $\begin{array}{l}17 \\
16\end{array}$ & very high & $2 c$ \\
\hline$O D P 1125$ & 19.6 & $\begin{array}{l}\text { Foraminifera } \\
\text { Alkenones }\end{array}$ & $\begin{array}{l}2 \\
2\end{array}$ & $\begin{array}{l}3 \\
4\end{array}$ & $\begin{array}{l}3 \\
3\end{array}$ & $\begin{array}{l}3 \\
3\end{array}$ & $\begin{array}{l}3 \\
4\end{array}$ & $\begin{array}{l}14 \\
16\end{array}$ & high & $3 c$ \\
\hline$O D P 1236$ & 25.4 & Foraminifera & 4 & 3 & 3 & 3 & 0 & 13 & high & $1 c$ \\
\hline ODP 1237 & 25.1 & $\begin{array}{l}\text { Foraminifera } \\
\mathrm{Mg} / \mathrm{Ca} \\
\text { Alkenones }\end{array}$ & $\begin{array}{l}4 \\
4 \\
4\end{array}$ & $\begin{array}{l}3 \\
2 \\
4\end{array}$ & $\begin{array}{l}2 \\
3 \\
3\end{array}$ & $\begin{array}{l}3 \\
3 \\
3\end{array}$ & $\begin{array}{l}3 \\
4 \\
4\end{array}$ & $\begin{array}{l}15 \\
16 \\
18\end{array}$ & very high & $1 c$ \\
\hline ODP 1239 & 25.6 & Foraminifera & 4 & 4 & 3 & 3 & 0 & 14 & high & $1 b$ \\
\hline Yabuta & 17.4 & $\begin{array}{l}\text { Ostracods } \\
\text { Mollusks }\end{array}$ & $\begin{array}{l}2 \\
2\end{array}$ & $\begin{array}{l}4 \\
4\end{array}$ & $\begin{array}{l}3 \\
3\end{array}$ & $\begin{array}{l}3 \\
3\end{array}$ & $\begin{array}{l}0 \\
0\end{array}$ & $\begin{array}{l}12 \\
12\end{array}$ & medium & $3 c$ \\
\hline Sasaoka & 16.3 & Ostracods & 2 & 1 & 3 & 3 & 0 & 9 & medium & $3 c$ \\
\hline Rangitikei River & 17.6 & Foraminifera & 2 & 4 & 2 & 2 & 0 & 10 & medium & $3 c$ \\
\hline East Kam-chatka & 7.5 & $\begin{array}{l}\text { Ostracods } \\
\text { Mollusks }\end{array}$ & $\begin{array}{l}2 \\
2\end{array}$ & $\begin{array}{l}4 \\
4\end{array}$ & $\begin{array}{l}3 \\
3\end{array}$ & $\begin{array}{l}1 \\
1\end{array}$ & $\begin{array}{l}0 \\
0\end{array}$ & $\begin{array}{l}10 \\
10\end{array}$ & medium & $3 c$ \\
\hline Karaginsky & 8.2 & $\begin{array}{l}\text { Ostracods } \\
\text { Mollusks }\end{array}$ & $\begin{array}{l}2 \\
2\end{array}$ & $\begin{array}{l}4 \\
4 \\
\end{array}$ & $\begin{array}{l}3 \\
3 \\
\end{array}$ & $\begin{array}{l}1 \\
1\end{array}$ & $\begin{array}{l}0 \\
0\end{array}$ & $\begin{array}{l}10 \\
10 \\
\end{array}$ & medium & $3 c$ \\
\hline \multicolumn{11}{|c|}{ Indian Ocean } \\
\hline ODP 709 & 27.6 & Foraminifera & 4 & 4 & 3 & 3 & 4 & 18 & very high & $1 c$ \\
\hline ODP 716 & 27.2 & Foraminifera & 3 & 4 & 2 & 3 & 3 & 15 & high & $2 c$ \\
\hline ODP 722 & 25.7 & Foraminifera & 4 & 3 & 2 & 3 & 3 & 15 & high & $1 c$ \\
\hline$O D P 754$ & 25.7 & Foraminifera & 3 & 4 & 3 & 3 & 0 & 13 & high & $2 c$ \\
\hline$O D P 757$ & 26.6 & Foraminifera & 3 & 3 & 2 & 3 & 4 & 15 & high & $2 c$ \\
\hline$O D P 758$ & 27.2 & Foraminifera & 3 & 4 & 3 & 3 & 0 & 13 & high & $2 c$ \\
\hline$O D P 763$ & 27.2 & Foraminifera & 4 & 4 & 3 & 3 & 4 & 18 & very high & $1 b$ \\
\hline
\end{tabular}


Table 1. Mean annual sea surface temperature estimates for the mid-Piacenzian PRISM interval, measures of the confidence of the estimates, and stratigraphic fidelity for the sites in the PRISM verification dataset.-Continued

[New or revised data are in italics. PRISM, Pliocene Research, Interpretation and Synoptic Mapping; SST, sea surface temperature; ${ }^{\circ} \mathrm{C}$, degree Celsius; $b_{1}$, age control; $b_{2}$, sample density; $b_{3}$, sample quality; $b_{4}$, proxy method; $b_{5}$, proxy performance; $\lambda$, confidence score; DSDP, Deep Sea Drilling Project; ODP, Ocean Drilling Program; $\mathrm{Mg} / \mathrm{Ca}$, magnesium to calcium ratio; $\mathrm{n} / \mathrm{a}$, cannot be rated using the stratigraphic fidelity rubric]

\begin{tabular}{|c|c|c|c|c|c|c|c|c|c|c|}
\hline \multirow{2}{*}{ Site } & \multirow{2}{*}{$\begin{array}{c}\text { Mean } \\
\text { annual } \\
\text { SST }\left({ }^{\circ} \mathrm{C}\right)\end{array}$} & \multirow{2}{*}{ Proxy } & \multicolumn{5}{|c|}{ Confidence attribute score } & \multicolumn{2}{|c|}{ Total confidence } & \multirow{2}{*}{$\begin{array}{c}\text { Stratigraphic } \\
\text { fidelity }\end{array}$} \\
\hline & & & $b_{1}$ & $b_{2}$ & $b_{3}$ & $b_{4}$ & $b_{5}$ & $\lambda$ & Category & \\
\hline \multicolumn{11}{|c|}{ Southern Ocean } \\
\hline AND-1B & -0.4 & Diatoms & 4 & 4 & 3 & 2 & 2 & 15 & high & $1 b$ \\
\hline E13-17 & 3.0 & Diatoms & 3 & 3 & 1 & 1 & 3 & 11 & medium & $2 c$ \\
\hline E14-8 & 4.1 & Diatoms & 3 & 3 & 1 & 1 & 2 & 10 & medium & $2 c$ \\
\hline E36-33 & 4.0 & Diatoms & 3 & 2 & 3 & 1 & 2 & 11 & medium & $2 c$ \\
\hline E50-28 & 2.1 & Diatoms & 3 & 2 & 3 & 1 & 2 & 11 & medium & $2 c$ \\
\hline E50-33 & 3.7 & Diatoms & 3 & 3 & 2 & 1 & 2 & 11 & medium & $2 c$ \\
\hline PS1448 & 1.9 & Front position & 3 & 2 & 2 & 1 & 3 & 11 & medium & $2 c$ \\
\hline DSDP 266 & 3.5 & Diatoms & 2 & 2 & 2 & 1 & 2 & 9 & medium & $3 c$ \\
\hline DSDP 274 & 1.4 & Diatoms & 2 & 3 & 3 & 1 & 3 & 12 & medium & $3 c$ \\
\hline DSDP 323 & 3.6 & Diatoms & 2 & 1 & 3 & 1 & 2 & 9 & medium & $3 c$ \\
\hline ODP 690 & 2.0 & Diatoms & 3 & 2 & 3 & 1 & 3 & 12 & medium & $2 c$ \\
\hline ODP 693 & 1.2 & Diatoms & 2 & 3 & 2 & 1 & 3 & 11 & medium & $3 c$ \\
\hline ODP 695 & 2.0 & Diatoms & 3 & 3 & 3 & 1 & 2 & 12 & medium & $2 c$ \\
\hline ODP 699 & 4.6 & Diatoms & 3 & 3 & 3 & 1 & 2 & 12 & medium & $2 c$ \\
\hline ODP 736 & 5.8 & Diatoms & 2 & 3 & 3 & 1 & 2 & 11 & medium & $3 c$ \\
\hline ODP 745 & 2.5 & Diatoms & 3 & 3 & 2 & 1 & 2 & 11 & medium & $2 c$ \\
\hline ODP 747 & 3.2 & Diatoms & 3 & 3 & 3 & 1 & 2 & 12 & medium & $2 c$ \\
\hline ODP 748 & 2.4 & Diatoms & 3 & 2 & 3 & 1 & 2 & 11 & medium & $2 c$ \\
\hline ODP 751 & 2.7 & Diatoms & 2 & 2 & 3 & 1 & 2 & 10 & medium & $3 c$ \\
\hline \multicolumn{11}{|c|}{ Northern High Latitudes } \\
\hline ODP 907 & 11.7 & $\mathrm{Mg} / \mathrm{Ca}$ & 3 & 1 & 3 & 3 & 3 & 13 & high & $2 c$ \\
\hline ODP 909 & 10.2 & $\begin{array}{l}\mathrm{Mg} / \mathrm{Ca} \\
\text { Alkenones }\end{array}$ & $\begin{array}{l}3 \\
3\end{array}$ & $\begin{array}{l}1 \\
2\end{array}$ & $\begin{array}{l}3 \\
0\end{array}$ & $\begin{array}{l}3 \\
3\end{array}$ & $\begin{array}{l}3 \\
3\end{array}$ & $\begin{array}{l}13 \\
11\end{array}$ & medium & $2 c$ \\
\hline North Sea & 13.6 & Mollusks & 1 & 2 & 3 & 2 & 4 & 12 & medium & $n / a$ \\
\hline Colvillian & 1.2 & Ostracods & 2 & 4 & 3 & 1 & 3 & 13 & high & $3 c$ \\
\hline Meighen Island & 1.7 & Ostracods & 2 & 4 & 3 & 1 & 0 & 10 & medium & $3 c$ \\
\hline
\end{tabular}

\footnotetext{
${ }^{1}$ Data from ODP 541 and 672 were combined into one time series.
} 


\section{$\frac{\mathbb{2}}{3}$}

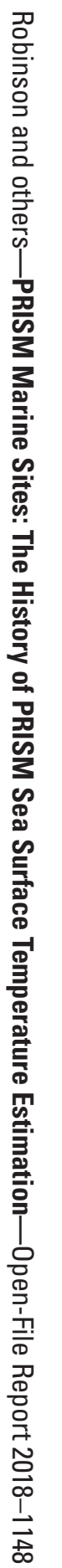

